
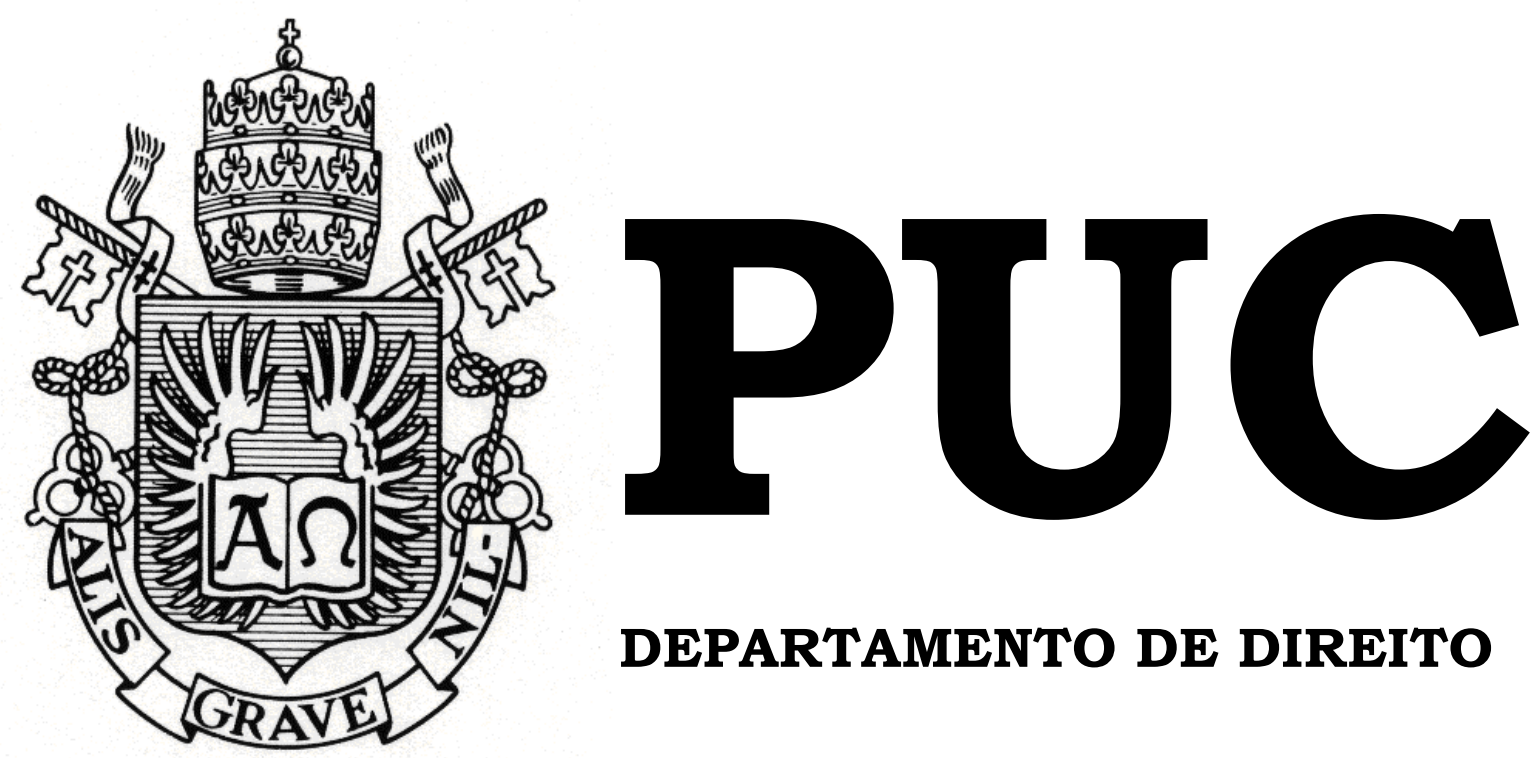

DEPARTAMENTO DE DIREITO

\title{
A DEFENSORIA PÚBLICA COMO AGENTE DO ACESSO À JUSTIÇA \\ Por
}

ISABELA HENRIQUES PESSANHA

ORIENTADORA: Regina Coeli Lisbôa Soares

2018.1

PONTIFÍCIA UNIVERSIDADE CATÓLICA DO RIO DE JANEIRO

RUA MARQUÊS DE SÃO VICENTE, 225 - CEP 22451-900

RIO DE JANEIRO - BRASIL 


\title{
A DEFENSORIA PÚBLICA COMO AGENTE DO ACESSO À JUSTIÇA
}

por

ISABELA HENRIQUES PESSANHA

\author{
Monografia apresentada ao \\ Departamento de Direito da \\ Pontifícia Universidade Católica do \\ Rio de Janeiro (PUC-Rio) para a \\ obtenção do Título de Bacharel em \\ Direito.
}

Orientadora: Regina Coeli Lisbôa Soares 


\section{AGRADECIMENTOS}

Acredito que, neste momento, palavras não são suficientes ou capazes de expressar toda a minha gratidão e amor para cada um que fez parte da minha trajetória ao longo desses cinco anos de graduação. Me sinto profundamente grata, lisonjeada e amada por ter ao meu lado pessoas tão indescritivelmente maravilhosas e incentivadoras.

Primeiramente, agradeço a Deus, por ser o meu maior exemplo de justiça e amor ao próximo, meu melhor amigo, por estar comigo em todos os momentos e por me amar de uma forma infinita. A Ele toda honra, toda glória e todo o louvor! Porque d'Ele, por Ele e para Ele são todas as coisas. "O Senhor é a minha força e o meu escudo; nele o meu coração confia, e dele recebo ajuda. Meu coração exulta de alegria, e com o meu cântico lhe darei graças" (Salmos 28:7).

Aos meus amados pais, Elias e Soraya, meus pilares, os amores da minha vida. Obrigada porque desde que nasci vocês são o meu portoseguro, o meu baluarte. Agradeço por me amarem incondicionalmente, por todo apoio, educação, e ensinamentos que vocês sempre me proporcionaram. Nunca poderei expressar com palavras o tamanho do meu amor, bem como toda a admiração que sinto por vocês. Posso dizer com toda certeza que vocês são as pessoas mais bondosas e íntegras que eu conheço, donos dos corações mais lindos e doadores desse mundo. Vocês dois me inspiram a ser uma pessoa melhor dia após dia. Amo vocês!

Aos meus queridos avós, Elias e Nelice, Amaro e Lúcia, por serem segundos pais para mim, por serem exemplos de amor e companheirismo e por me ensinarem o verdadeiro valor de uma família. Agradeço especialmente à minha preciosa avó Lucinha, por me ensinar a ter uma fé inabalável nas diversas circunstâncias da vida e a jamais desistir.

Aos meus tios e primos, que fazem parte da minha história. Obrigada por serem pessoas tão especiais para mim! Sem a presença constante e 
contagiante de cada um, a minha vida jamais seria a mesma. Amo demais todos vocês!

Ao meu namorado Matheus Nazar, por toda a força e por todo o apoio. Obrigada por sonhar cada conquista junto comigo. Você é um presente de Deus para mim!

Aos meus amigos de toda a vida, aqueles que são mais chegados que irmãos, agradeço por serem os melhores e por estarem comigo em todos os momentos da minha vida, independentemente da situação.

Às minhas amigas da PUC-Rio, especialmente à Paula Guedes, Luiza Freire, Laís Gouvêa, Thainá Mamede e Beatriz Mattos. Obrigada por tornarem esses cinco anos da faculdade um período alegre, leve, divertido e cheio de cumplicidade. Tenho certeza que nada seria igual sem vocês e espero que continuemos amigas, só que agora como advogadas.

Aos meus professores da PUC-Rio, por todas as instruções ao longo desses anos, por me ensinarem o que é o verdadeiro Direito e por me darem embasamento para seguir em frente e lutar pela justiça.

Agradeço especialmente à minha tão estimada orientadora Regina Coeli Lisbôa Soares, por sua disponibilidade, conselhos, sugestões, afeto e por todo auxílio. O meu muito obrigada! A senhora, com certeza, é uma das minhas grandes influências pela paixão que nutro pelo Direito Constitucional. Suas aulas sempre serão inesquecíveis para mim. Posso afirmar que é uma honra ter sido sua aluna e agora sua orientanda.

Agradeço também à professora Ana Paula Santoro, por todo o encorajamento e estímulo, por ter se tornado uma grande amiga e ser sempre tão solícita em querer ouvir, ajudar e oferecer carinho e conforto. Sou grata também à professora Isabella Guerra por ter me auxiliado com as entrevistas da Monografia e por ter me apresentado profissionais tão competentes.

Aos funcionários da PUC-Rio, por sempre me receberem na faculdade com um sorriso no rosto e por cuidarem do bem-estar de todos os alunos. 
À Rita Oliveira, por sempre acreditar que sou capaz, por me ouvir, por cuidar da minha casa e de mim com tanto afinco. Meu carinho por você é imenso!

Ao Marcos, sempre disponível a me levar na faculdade ou em qualquer outro lugar que eu precisasse. Nunca esquecerei que foi você quem me levou para fazer a prova na PUC-Rio.

À Juliana Sampaio, que de coordenadora do Ensino Médio virou uma tia postiça para mim, sempre me ajudando com as mil cópias de impressão para os meus estudos.

E, por fim, agradeço aos Defensores Públicos Acidália Tymchak, André Ordacgy, Cleber Francisco Alves, João Henrique Vianna e Rogério Rabe, que disponibilizaram o seu tempo auxiliando-me com a finalização da Monografia para obtenção de título de bacharel em Direito. Desejo que vocês continuem sendo excelentes profissionais, lutando sempre pelo efetivo acesso à justiça para aqueles que precisam. 


\section{RESUMO}

PESSANHA, Isabela Henriques. A Defensoria Pública como Agente do Acesso à Justiça. Rio de Janeiro: 2018: 120 p. Monografia de final de curso. Departamento de Direito da Pontifícia Universidade Católica do Rio de Janeiro - PUC-Rio.

A monografia tem como escopo principal consagrar a atuação da Defensoria Pública, como uma Instituição permanente e essencial ao amplo e efetivo acesso à justiça. De forma a colaborar com uma sociedade mais democrática, igualitária, capaz de superar as desigualdades sociais, econômicas e culturais, bem como, promover integral e gratuitamente o acesso aos Direitos Fundamentais aos mais necessitados e vulneráveis. Contudo, a Defensoria Pública enfrenta alguns obstáculos que precisam ser superados em prol da assistência jurídica, que engloba não apenas o acesso ao Poder Judiciário, mas também à atividade extrajudicial, à consultoria e à orientação jurídica. Desse modo, o presente trabalho possui como intuito e desafio a elaboração e a implementação de soluções para que o exercício da Instituição seja plenamente acessível, competente e eficaz, apto a minimizar os conflitos de interesses existentes na coletividade e preconizar a dignidade da pessoa humana.

Palavras-Chave: Defensoria Pública; Acesso à Justiça; Assistência Jurídica Integral e Gratuita; Dignidade da Pessoa Humana; Direitos Fundamentais; Igualdade; Democracia; IV Diagnóstico da Defensoria Pública no Brasil. 


\section{ABSTRACT}

PESSANHA, Isabela Henriques. The Public Defender as an Agent of Access to Justice. Rio de Janeiro: 2018: 120 p. Monograph. Law department of Pontifícia Universidade Católica do Rio de Janeiro - PUCRio.

This paper aims to honoring the action of the Public Defender, as a permanent Institution and essential to the extensive and effective access to justice. In order to collaborate with a more democratic and egalitarian society, capable of overcoming the social, economical and cultural inequalities, as well as promote full and pro bono access to Fundamental Rights to the mostly vulnerable and disadvantaged people. However, the Public Defender faces obstacles that need to be overcome in favor or legal assistance, which includes not only the access to the Judiciary, but also extrajudicial activity, consulting and legal guidance. Therefore, the current work has as its purpose and challenge the elaboration and implementation of solutions. Which means that the exercise of the Institution can be fully accessible, qualified and effective. Also, able to minimize the conflicts of interests in the community and to advocate the dignity of the human being.

Keywords: Public Defender; Access to Justice; Integral and Free Legal Assistance; Dignity of Human Person; Fundamental Rights; Equality; Democracy; IV Diagnosis of the Public Defender in Brazil. 
"Erga a voz em favor dos que não podem defender-se, seja o defensor de todos os desamparados. Erga a voz e julgue com justiça; defenda os direitos dos pobres e dos necessitados". Provérbios 31: 8-9, NVI. 


\section{SUMÁRIO}

INTRODUÇÃO....................................................................................................9

CAPÍTULO 1 - OS DIREITOS FUNDAMENTAIS E O ACESSO À JUSTIÇA COMO O PRINCÍPIO INSTRUMENTAL-BÁSICO...........12

1.1 Teoria Dimensional e a Historicidade dos Direitos Fundamentais....12

1.2 Direitos Fundamentais na Constituição Federal Brasileira de 1988..18

1.3 O Conceito e a Eficácia dos Direitos Fundamentais...........................20

1.4 As Características e Classificações dos Direitos Fundamentais .........23

$1.5 \mathrm{O}$ Princípio do Acesso à Justiça como Instrumento Primário dos

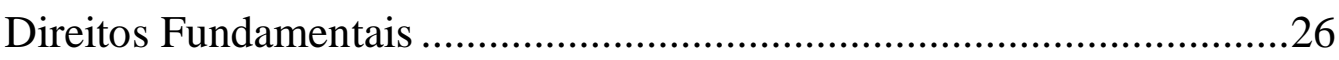

CAPÍTULO 2 - A DEFENSORIA PÚBLICA............................................39

2.1 Histórico da Instituição da Defensoria Pública no Brasil e a

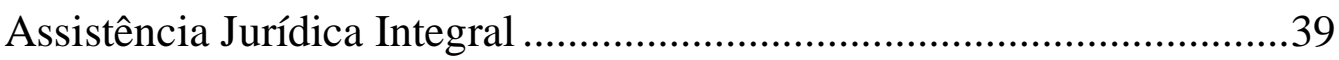

2.2 Legislação Atual da Defensoria Pública no Brasil ...............................46

2.3 Características da Defensoria Pública.................................................49

2.4 Natureza Jurídica da Defensoria Pública ................................................53

2.5 Objetivos da Defensoria Pública.......................................................5

2.6 Princípios Institucionais da Defensoria Pública ..................................62

2.7 Funções Institucionais da Defensoria Pública ......................................66

CAPÍTULO 3 - A DEFENSORIA PÚBLICA E O SEU PAPEL NA PROMOÇÃO E DESENVOLVIMENTO DO ACESSO À JUSTIÇA.72

3.1 Problemas enfrentados pela Defensoria Pública que dificultam a efetividade do Acesso à Justiça ..............................................................76

3.1.1 As Defensorias Públicas Estaduais e seus maiores desafios............79

3.1.2 As Defensorias Públicas Federais e seus maiores desafios .............89

3.2 Possíveis Soluções no Cenário das Defensorias Públicas ...................96

3.3 Algumas Vozes: considerações acerca da Defensoria Pública e do Acesso à Justiça ...............................................................................102

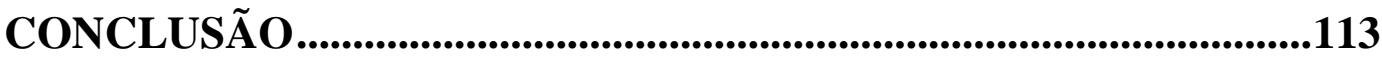

REFERÊNCIAS BIBLIOGRÁFICAS..................................................115 


\section{INTRODUÇÃO}

É imprescindível começar a presente exposição citando a Constituição da República Federativa do Brasil de 1988, pois foi ela a grande responsável por voltar a estabelecer o Estado Democrático de Direito no país e por consagrar a dignidade da pessoa humana, dando valor, prestígio e importância aos indivíduos, colocando-os no ápice do ordenamento jurídico brasileiro. Por conta disso, um sistema mais igualitário começou a ganhar impulso, o que foi de enorme auxílio para o fortalecimento da inclusão social e para a diminuição das diferenças econômicas, sociais e culturais. Fatores que sempre existiram e distanciaram as pessoas uma das outras, culminando em amplas desigualdades no âmbito do acesso à justiça e na concretização dos direitos fundamentais.

No que tange ao acesso à justiça e a efetivação dos direitos e garantias fundamentais, o texto constitucional tratou de prever uma Instituição, com um viés totalmente democrático, capaz de fornecer amparo e defesa para as pessoas mais vulneráveis da sociedade, a Defensoria Pública. Isso porque, sem uma assistência jurídica integral e gratuita, seria impossível para os cidadãos mais carentes buscar e alcançar seus direitos. Dessa forma, é notável perceber que a Defensoria surge com o escopo de promover dignidade e humanidade às pessoas, lutando para consolidar e fornecer uma real exequibilidade do "direito dos direitos". Pois sem o acesso à justiça não haveria como atingir e obter as prerrogativas constitucionais e legalmente previstas.

Partindo dessa perspectiva, o objetivo da monografia encontra respaldo na aclamação da Defensoria Pública como uma Instituição atuante e permanente, que busca promover e resguardar os direitos, sejam eles individuais ou coletivos. Portanto, o maior propósito do trabalho é potencializar a Defensoria Pública como um verdadeiro agente do acesso à 
justiça aos juridicamente necessitados e, automaticamente, enaltecer o seu papel fundamental no cenário vigente.

Inicialmente, o primeiro capítulo da monografia fará uma análise expositiva dos Direitos Fundamentais, explicitando suas características, gerações, classificações, eficácia e o tratamento constitucional que é dado a eles. Isso tudo será de extrema relevância, tendo em vista que o acesso à justiça é um direito fundamental instrumental, no sentido de ser um mecanismo catalisador para que as pessoas tenham a possibilidade de perseguir os seus direitos. Dessa forma, será apresentada no mesmo capítulo a noção do acesso à justiça, as suas ondas renovatórias, bem como os maiores entraves para lográ-lo. Por meio dessa apresentação, a Defensoria Pública terá a sua função ressaltada como uma Instituição que preza pela efetividade e concretização deste acesso.

O segundo capítulo tem como finalidade revelar o desenvolvimento histórico da Defensoria Pública no Brasil, as suas principais funções, os seus princípios institucionais e objetivos, assim como as suas características, natureza jurídica e as legislações em vigor responsáveis por reger e disciplinar o seu exercício. Toda a narrativa está conectada com o acesso à justiça, de modo a valorizar as peculiaridades da Instituição em função deste direito instrumental e fundamental.

Por fim, o terceiro capítulo do trabalho tem como intuito primordial a demonstração do atual cenário da Defensoria Pública no Brasil, tanto em âmbito Estadual como em âmbito Federal. Vale dizer que, essa pesquisa utiliza como fonte o "IV Diagnóstico da Defensoria Pública no Brasil", doutrinas de renomados autores e até mesmo entrevistas com membros que fazem parte da Instituição e lidam no seu cotidiano com a beleza e os obstáculos da Defensoria Pública. Esse estudo torna-se de vital importância, porque é necessário compreender o real quadro da Instituição e os seus maiores desafios, procurando solucioná-los da melhor maneira. Assim, o último capítulo também buscará encontrar possíveis soluções que possam 
modificar e superar essas dificuldades, de modo a tornar o acesso à justiça mais amplo e efetivo para a parte da população que mais necessita.

Com isso, fica claro que a principal preocupação da monografia é o fomento do acesso à justiça no Brasil por meio da Defensoria Pública. E que a maior intenção do trabalho é ser uma ferramenta de apoio na busca de remédios qualificados para a modificação do presente contexto da Instituição, sempre destacando a atribuição e o ofício da Defensoria num Estado Democrático de Direito. 


\section{CAPÍTULO 1 - OS DIREITOS FUNDAMENTAIS E O ACESSO À JUSTIÇA COMO O PRINCÍPIO INSTRUMENTAL-BÁSICO}

Para iniciar o presente estudo, é necessário desvendar as diversas facetas que os Direitos Fundamentais possuem. O seu estudo torna-se imprescindível para esclarecer a real importância do acesso à justiça na ordem jurídica para os grupos menos amparados da sociedade brasileira.

\subsection{Teoria Dimensional e a Historicidade dos Direitos Fundamentais}

É relevante elucidar a forma pela qual os Direitos Fundamentais foram inseridos nas sociedades e como foram ganhando impulso e importância ao longo dos anos. Para isso, é necessário contemplar e realizar um estudo histórico, tendo em vista que esses Direitos possuem como uma das suas principais características a historicidade.

A amplitude e a natureza deles não permaneceram estáticas, evoluíram, enriquecendo-se com conquistas e transformações das ideias e do pensamento da coletividade, como assevera Miguel José Faria ${ }^{1}$

Nesse sentido, Norberto Bobbio diz que:

Os direitos do homem, por mais fundamentais que sejam, são direitos históricos, ou seja, nascidos em certas circunstâncias, caracterizados por lutas em defesa de novas liberdades contra velhos poderes, e nascidos de modo gradual, não todos de uma vez e nem de uma vez por todas ${ }^{2}$.

É primordial ressaltar que "a ampliação e transformação dos direitos fundamentais do homem no evolver histórico dificulta definir-lhes um conceito sintético e preciso"3. Assim, podem ser utilizadas diversas nomenclaturas para determiná-los, as mais aceitas e utilizadas por

\footnotetext{
${ }^{1}$ FARIA, José Miguel. Direitos Fundamentais e Direitos do Homem. v. 1. $3^{\mathrm{a}}$ ed., Instituto Superior de Ciências Policiais e Segurança Interna, 2001. p. 4.

${ }^{2}$ BOBBIO, Norberto. A Era dos Direitos. $1^{\text {a }}$ ed. 12. tir. Rio de Janeiro: Campus, 1992. p. 5.

${ }^{3}$ SILVA, José Afonso da. Curso de Direito Constitucional Positivo. $37^{\mathrm{a}}$ ed., São Paulo: Malheiros, 2013. p. 177.
} 
doutrinadores conceituados são: "direitos naturais", "direitos públicos subjetivos", "liberdades públicas", "direitos morais", "direitos dos povos", "direitos humanos", "direitos do homem", "liberdades fundamentais", "direitos individuais" e "direitos fundamentais do homem".

Dessa forma, torna-se questionável o emprego da terminologia mais adequada. Vale dizer, que aqui será adotada a teoria que explicita que, se há uma norma que protege o indivíduo do Estado e de outro sujeito dentro de um documento interno, no caso, a Constituição, a expressão correta a ser utilizada é "direitos fundamentais". Konrad Hesse, citado pelo jurista Paulo Bonavides, mostra que os "direitos fundamentais são aqueles direitos que o direito vigente qualifica como tais"4. Por outro lado, é defendido que se há uma norma estabelecida nas declarações, tratados e convenções internacionais, a nomeação aplicada frequentemente é a de "direitos humanos". Se não houver previsão em nenhum diploma, e for um princípio ou valor elementar, a designação abordada comumente é a de "direitos do homem".

Ingo Wolfgang Sarlet defende essa mesma tese:

(...) o termo direitos fundamentais se aplica para aqueles direitos do ser humano reconhecidos e positivados na esfera do direito constitucional positivo de determinado Estado, ao passo que a expressão direitos humanos guardaria relação com os documentos de direito internacional, por referir-se àquelas posições jurídicas que se reconhecem ao ser humano como tal, independentemente de sua vinculação com determinada ordem constitucional, e que, portanto aspiram à validade universal, para todos os povos e tempos, de tal sorte que revelam um inequívoco caráter supranacional ${ }^{5}$.

Esclarecida a temática referente a nomenclatura, resta perquirir a transformação e o aperfeiçoamento dos direitos fundamentais ao longo do tempo. Para isso, é preciso apontar a Teoria Dimensional dos Direitos

\footnotetext{
${ }^{4}$ HESSE, Konrad. Grundzugedes Verfassungsrechts der Bundesrepublik Deutschland, $13^{\mathrm{a}}$ ed. aum. Heidelberg. 1982 apud BONAVIDES, Paulo. Curso de Direito Constitucional. $29^{a}$ ed., São Paulo: Malheiros Editores, 2014. p. 574.

${ }^{5}$ SARLET, Ingo Wolfgang. A Eficácia dos Direitos Fundamentais. Uma teoria geral dos direitos fundamentais na perspectiva constitucional. $5^{\text {a }}$ ed. Porto Alegre: Livraria do Advogado, 2005. p. $35-36$.
} 
Fundamentais, que consagra três gerações ${ }^{6}$ distintas. Entretanto, para alguns autores, há outras que acompanham a evolução histórica.

A primeira geração de direitos fundamentais centrou-se na Revolução Francesa do século XVIII, que consagrou três princípios primordiais: liberdade, igualdade e fraternidade. Essa Revolução continha como fator culminante a concentração de poderes fixada nas mãos do rei. A supremacia que o monarca detinha trouxe como consequência uma intensa insegurança jurídica e atingia desproporcionalmente os interesses da burguesia.

Quando o povo conseguiu assumir o comando, diversas questões foram suscitadas e defendidas fervorosamente. Uma das grandes modificações implementadas teve como objeto a menor participação do Estado na vida cotidiana e particular dos indivíduos. Por consequência, pode-se dizer que os direitos fundamentais surgem com o estabelecimento de uma limitação ao poder de império do Estado no patrimônio individual das pessoas.

\section{Segundo Paulo Bonavides:}

Os direitos da primeira geração são os direitos da liberdade, os primeiros a constarem do instrumento normativo constitucional, a saber, os direitos civis e

\footnotetext{
${ }^{6}$ A nomenclatura "geração" é criticada por alguns doutrinadores, pois este termo poderia estimular o pensamento de que os direitos fundamentais foram evoluindo com o passar dos anos e haveria uma substituição gradual de cada um deles, de forma que não poderiam coexistir, visto que seriam sucessivos. Com isso, surge a expressão "dimensão", defendida por autores como Ingo Wolfgang Sarlet: "Em que pese o dissídio na esfera terminológica, verifica-se crescente convergência de opiniões no que concerne à ideia que norteia a concepção das três (ou quatro, se assim preferirmos) dimensões dos direitos fundamentais, no sentido de que estes, tendo tido sua trajetória existencial inaugurada com o reconhecimento formal nas primeiras Constituições escritas dos clássicos direitos de matriz liberal-burguesa, se encontram em constante processo de transformação, culminando com a recepção, nos catálogos constitucionais e na seara do Direito Internacional, de múltiplas e diferenciadas posições jurídicas, cujo conteúdo é tão variável quanto transformações ocorridas na realidade social, política, cultural e econômica ao longo dos tempos. Assim sendo, a teoria dimensional dos direitos fundamentais não aponta, tão-somente, para o caráter cumulativo do processo evolutivo e para a natureza complementar de todos os direitos fundamentais, mas afirma, para além disso, sua unidade e indivisibilidade no contexto do direito constitucional interno e, de modo especial, na esfera do moderno 'Direito Internacional dos Direitos Humanos". SARLET, Ingo Wolfgang. A eficácia dos direitos fundamentais. $9^{\mathrm{a}}$ ed., rev., ampl. Porto Alegre: Livraria do Advogado, 2008. p. 53.
} 
políticos, que em grande parte correspondem, por um prisma histórico, àquela fase inaugural do constitucionalismo do Ocidente ${ }^{7}$.

Portanto, esses direitos - civis e políticos - eram estabelecidos nas Constituições vigentes da época e tinham como intuito proteger o indivíduo da opressão do Estado, estipulando direitos de resistência e de oposição ao seu domínio. Paulo Bonavides defende que são direitos que, prioritariamente, valorizam o homem-singular.

Esse período foi classificado como "Estado Mínimo", tendo em vista a ocorrência de uma abstinência estatal e o engajamento do liberalismo político, econômico e social. Sendo assim, os direitos desta época podem ser identificados como "liberdades negativas".

A segunda geração de direitos concentrou-se no século $\mathrm{XX}$ e adquiriu forte impulsionamento, pois a população, que até então encontrava-se livre, foi transformando-se em opressiva, prejudicando e reprimindo as camadas populares menos favorecidas daquele tempo. Por conseguinte, é inequívoco observar a prevalência do indivíduo em detrimento da coletividade.

Ingo Wolfgang Sarlet assevera:

O impacto da industrialização e os graves problemas sociais e econômicos que a acompanharam, as doutrinas socialistas e a constatação de que a consagração formal de liberdade e de igualdade não gerava a garantia de seu efetivo gozo acabaram, já no decorrer do século XIX, gerando amplos movimentos reivindicatórios e o reconhecimento progressivo de direitos atribuindo ao Estado comportamento ativo na realização da justiça social ${ }^{8}$.

Este período concentrou-se no reconhecimento dos direitos sociais, culturais e econômicos, bem como no advento dos direitos coletivos. Estas normas tiveram como escopo a reflexão antiliberal que culminava na época dos direitos de primeira geração e a preconização do princípio da igualdade.

\footnotetext{
${ }^{7}$ BONAVIDES, 2014, p. 577.

${ }^{8}$ SARLET, Ingo Wolfgang. A eficácia dos direitos fundamentais. $9^{a}$ ed., rev., ampl. Porto Alegre: Livraria do Advogado, 2008. p. 55.
} 
Tais direitos tiveram como grande estímulo algumas constituições que surgiram na época. A título de exemplo, pode-se citar a Constituição Mexicana de 1917, caracterizada como a primeira a instituir os direitos sociais numa Carta Constitucional, e a Constituição Alemã de Weimar de 1919, responsável pela decretação de uma atuação estatal preponderante na promoção de direitos sociais, impulsionando, dessa forma, uma nova modificação na sociedade. A preocupação, então, já não estava mais pautada exclusivamente no indivíduo, mas sim, na coletividade.

Paulo Bonavides afirma que esses direitos da segunda geração exigem do Estado determinadas prestações materiais. Reivindica-se a realização de políticas públicas, instituindo obrigações para o Estado voltadas principalmente à manutenção e promoção dos direitos à educação, saúde, previdência, entre outros.

Desse modo, aprendemos com o doutrinador:

Os direitos sociais fizeram nascer a consciência de que tão importante quanto salvaguardar o indivíduo, conforme ocorreria na concepção clássica dos direitos da liberdade, era proteger a instituição, uma realidade social muito mais rica e aberta à participação criativa e à valoração da personalidade que o quadro tradicional da solidão individualista, onde se formara o culto liberal do homem abstrato e insultado, sem a densidade dos valores existenciais, aqueles que unicamente o social proporciona em toda a plenitude ${ }^{9}$.

Da mesma forma defende George Marlmelstein:

Os direitos de primeira geração tinham como finalidade, sobretudo, possibilitar a limitação do poder estatal e permitir a participação do povo nos negócios públicos. Já os direitos de segunda geração possuem um objetivo diferente. Eles impõem diretrizes, deveres e tarefas a serem realizadas pelo Estado, no intuito de possibilitar aos seres humanos melhores qualidade de vida e um nível de dignidade como pressuposto do próprio exercício da liberdade. Nessa acepção, os direitos fundamentais de segunda geração funcionam como uma alavanca ou uma catapulta capaz de proporcionar o desenvolvimento do ser humano, fornecendolhe as condições básicas para gozar, de forma efetiva, a tão necessária liberdade ${ }^{10}$.

\footnotetext{
${ }^{9}$ BONAVIDES, 2014, p. 579.

${ }^{10}$ MARMELSTEIN, George. Curso de direitos fundamentais. São Paulo: Atlas, 2008. p. 50.
} 
José Afonso da Silva, em sua obra "Curso de Direito Constitucional Positivo", aponta algumas condições para a formulação dos direitos fundamentais e coloca o Intervencionismo Estatal em posição de destaque, ressaltando "que o Estado deve atuar no meio econômico e social, a fim de cumprir uma missão protetora das classes menos favorecidas, mediante prestações positivas" ${ }^{11}$.

Logo, é possível perceber o ingresso de um intervencionismo estatal neste período, que é conhecido e determinado como "Estado Social", demonstrando que o Estado deixa de ser um agente ausente para tornar-se um ator em prol da proteção de uma igualdade entre os indivíduos.

No final do século XX, é possível perceber a introdução dos direitos de terceira geração, que consagram direitos metaindividuais, transindividuais e difusos homogêneos. Estes direitos são caracterizados por irem além da pessoa individual. São direitos arrolados de acordo com a fraternidade e solidariedade e não se prendem apenas aos direitos individuais e coletivos.

Vale mencionar que nesse período há uma forte preocupação com aqueles que ainda não são sujeitos de direitos e deveres, ou seja, há uma maior atenção e precaução com o futuro e as novas gerações.

A terceira geração está sistematizada por meio de direitos que são "dotados de altíssimo teor de humanismo e universalidade" 12 ."Emergiram eles da reflexão sobre temas referentes ao desenvolvimento, à paz, ao meio ambiente, à comunicação e ao patrimônio comum da humanidade"13.

Como elucida Paulo Bonavides:

A história dos direitos humanos - direitos fundamentais de três gerações sucessivas e cumulativas, a saber, direitos individuais, direitos sociais e direitos difusos - é a história mesma da liberdade moderna, da separação e limitação de

\footnotetext{
${ }^{11}$ SILVA, 2013, p. 177.

${ }^{12}$ BONAVIDES, 2014, p. 583.

${ }^{13}$ Ibid., p. 584.
} 
poderes, da criação de mecanismos que auxiliam o homem a concretizar valores cuja identidade jaz primeiro na Sociedade e não nas esferas do poder estatal ${ }^{14}$.

Para finalizar o exame histórico, é necessário citar que alguns doutrinadores defendem a existência de uma quarta geração de direitos concentrada na globalização dos direitos fundamentais. Paulo Bonavides é um dos estudiosos que defendem esses direitos relacionando-os com a democracia, a informação e ao pluralismo. Segundo o autor, estes sintetizam o futuro da cidadania e o porvir da liberdade de todos os povos, e somente com eles seria realmente possível e legítima a globalização política. Ele explicita que:

Os direitos da quarta geração não somente culminam a objetividade dos direitos das duas gerações antecedentes como absorvem - sem, todavia, removê-la - a subjetividade dos direitos individuais, a saber, os direitos da primeira geração ${ }^{15}$.

\subsection{Direitos Fundamentais na Constituição Federal Brasileira de 1988}

A Constituição da República Federativa do Brasil de 1988 é conhecida por todos como a "constituição cidadã" por ser amplamente democrática e garantidora de direitos.

No próprio preâmbulo, que tem valor interpretativo, é notório perceber valores sociais e fraternais que inauguram os ditames de um verdadeiro Estado Democrático de Direito. Além disso, todo o texto da Lei Maior é pautado em preceitos humanistas, colocando em posição de primazia a pessoa humana, sendo ela um dos fundamentos do Estado Brasileiro, consagrando assim o compromisso imperioso com o ser humano.

É significativo esclarecer também que a Constituição Federal quanto a sua mutabilidade, é classificada como rígida, ou seja, é possível que o texto constitucional seja alterado, entretanto, isto depende de um trâmite mais rigoroso. Este procedimento vem disciplinado no artigo 60 que tem

\footnotetext{
${ }^{14}$ Ibid., p. 589.

${ }^{15}$ BONAVIDES, 2014, p. 586.
} 
como abordagem predominante a temática envolvendo as emendas constitucionais. Logo, é plausível dizer que a Constituição só poderá ser emendada por um processo mais dificultoso respeitando todos os requisitos normativos.

No mesmo dispositivo citado acima, no $\S 4^{\circ}$, é possível perceber o que se denomina "cláusula pétrea". E o inciso IV deste mesmo parágrafo expressa de forma clara a proteção que os Direitos Fundamentais devem possuir no ordenamento jurídico brasileiro, vez que eles são considerados cláusulas pétreas, diante da impossibilidade de serem alterados e modificados por emendas constitucionais, enaltecendo o papel essencial que eles desempenham na proteção da pessoa humana.

Importante mencionar que, apesar de serem cláusulas pétreas, isso não impede a criação e o surgimento de novos direitos fundamentais no ordenamento jurídico. O que é expressamente proibido, na verdade, é a supressão e a revogação destes direitos. A partir disso, fica claro que, sem eles e suas salvaguardas, torna-se impossível vislumbrar a dignidade da pessoa humana como um dos fundamentos do Estado Democrático de Direito.

Alguns doutrinadores defendem que os Direitos Fundamentais estão centralizados apenas em uma parte do texto constitucional, citando muitas vezes os primeiros capítulos e somente o artigo $5^{\circ}$. Contudo, a doutrina majoritária defende que os Direitos Fundamentais estão "espalhados" por toda a Lei Maior, ampliando ainda mais a defesa destes.

Alicerçados nisso, é evidente que os Direitos Fundamentais receberam uma forte relevância estimulada pelo constituinte originário, revelando um grande avanço e o prestígio que eles possuem na ordem jurídica brasileira. 


\subsection{O Conceito e a Eficácia dos Direitos Fundamentais}

Os Direitos Fundamentais, como visto no primeiro sub-tópico, ganharam forte incidência quando tinham como único objetivo limitar o poder estatal de forma a impedir que o Estado exercesse abusivamente o seu poderio.

Entretanto, nos dias atuais, é possível fazer uma releitura acerca do seu propósito e afirmar que estes Direitos têm como principal escopo a sustentação do ser humano. São direitos inerentes à pessoa humana e, portanto, designados a todos. Buscam tutelar a vida, a liberdade, a igualdade e a existência digna e justa.

Nesse sentido, os Direitos Fundamentais são considerados:

Indispensáveis à pessoa humana, necessários para assegurar a todos uma existência digna, livre e igual. Não basta ao Estado reconhecer direitos formalmente; deve buscar concretizá-los, incorporá-los no dia a dia dos cidadãos e de seus agentes ${ }^{16}$.

\section{Segundo José Afonso da Silva:}

No qualificativo fundamentais acha-se a indicação de que se trata de situações jurídicas sem as quais a pessoa humana não se realiza, não convive e, às vezes, nem mesmo sobrevive; fundamentais do homem no sentido de que a todos, por igual, devem ser, não apenas formalmente reconhecidos, mas concreta e materialmente efetivados. Do homem, não como o macho da espécie, mas no sentido de pessoa humana. Direitos fundamentais do homem significa direitos fundamentais da pessoa humana ou direitos fundamentais ${ }^{17}$.

Em relação a natureza dos Direitos Fundamentais, pode-se afirmar, que "são situações jurídicas, objetivas e subjetivas, definidas no direito positivo, em prol da dignidade, igualdade e liberdade da pessoa humana"18. José Afonso da Silva afirma que sua natureza passara a ser constitucional,

\footnotetext{
${ }^{16}$ PINHO, Rodrigo César Rebello. Teoria geral da Constituição e direitos fundamentais. São Paulo: Saraiva, 2010. p. 96.

${ }^{17}$ SILVA, 2013, p. 180.

${ }^{18}$ Ibid., p. 181.
} 
fazendo alusão ao autor Paolo Barile ${ }^{19}$, defendendo que faz parte da estrutura e do próprio conceito de Constituição.

Nessa perspectiva:

São direitos constitucionais na medida em que se inserem no texto de uma constituição ou mesmo constem de simples declaração solenemente estabelecida pelo poder constituinte. São direitos que nascem e se fundamentam, portanto, no princípio da soberania popular ${ }^{20}$.

Por meio da conceituação dada por José Afonso da Silva, podemos mencionar aqui também os dois aspectos dos Direitos Fundamentais que estão interligados com a sua natureza.

No sentido subjetivo, entende-se que é a maneira pela qual as pessoas buscam perquirir a observância e a tutela das suas prerrogativas, ou seja, é o próprio titular do direito que visa perseguir a sua concretização, tenha no polo passivo da relação o Estado ou um particular.

Nos moldes de Canotilho: "o direito subjetivo consagrado por uma norma de direito fundamental reconduz-se, assim, a uma relação trilateral entre o titular, o destinatário e o objeto do direito" ${ }^{21}$. Este viés subjetivo permite que o indivíduo ou até mesmo a coletividade alcance a efetividade de suas atribuições perante o Estado, satisfazendo, assim, seus interesses jurídicos, instituídos estes pelo ordenamento jurídico.

O segundo sentido é o objetivo, que é aquele que impõe, principalmente ao poder público, o emprego de instrumentos e soluções viáveis que permitam colocar em prática e em posição de notoriedade os Direitos Fundamentais, tendo em consideração a sua importância para um verdadeiro e efetivo Estado Democrático de Direito.

Dessa forma, a dimensão objetiva obriga o Estado e todos os seus poderes - Executivo, Legislativo e Judiciário - a realizarem a promoção de

\footnotetext{
${ }^{19}$ Ibid., p. 181.

${ }^{20}$ Ibid., p. 182.

${ }^{21}$ CANOTILHO, José Joaquim Gomes. Direito Constitucional. $5^{\text {a }}$ ed. Coimbra: Almedina, 1992. p. 544.
} 
medidas que auxiliem na preservação dos Direitos Fundamentais. Vale dizer que este resguardo não deve ocorrer apenas quando há uma violação de um determinado direito, isto é, este amparo deve ser repressivo, mas, também, preventivo.

Um grande exemplo para ilustrar a esfera objetiva dos Direitos Fundamentais diz respeito a temática que será abordada na monografia. Sabe-se que a Constituição Federal Brasileira assegura em seu artigo $5^{\circ}$, inciso LXXIV, uma assistência jurídica gratuita aos que são considerados hipossuficientes, por consequência, a atuação estatal é imprescindível, considerando-se a necessidade do emprego de providências para tornar esse direito realmente possível e efetivo.

O ministro Gilmar Ferreira Mendes explica:

Os direitos fundamentais são, a um só tempo, direitos subjetivos e elementos fundamentais da ordem constitucional objetiva. Enquanto direitos subjetivos, os direitos fundamentais outorgam aos titulares a possibilidade de impor os interesses em face dos órgãos obrigados. Na sua dimensão como elemento fundamental da ordem constitucional objetiva, os direitos fundamentais - tanto aqueles que não asseguram primariamente, um direito subjetivo quanto aqueloutros, concebidos como garantias individuais - forma a base do ordenamento jurídico de um Estado de Direito Democrático ${ }^{22}$.

Diante disso, é razoável indagar qual é a real eficácia desses Direitos Fundamentais. A Constituição Federal preconiza no artigo $5^{\circ}, \S 1^{\circ}$, que as normas definidoras dos direitos e garantias fundamentais têm aplicação imediata. Com isso, é presumível afirmar que a eficácia é plena.

No entanto, José Afonso da Silva ressalta que mesmo que o Texto Constitucional consagre a eficácia plena, existem direitos que dependem do seu enunciado, pois se trata de assunto que está em função do Direito

\footnotetext{
${ }^{22}$ MENDES, Gilmar Ferreira. Direitos fundamentais e controle de constitucionalidade: Estudos de Direito Constitucional. $3^{a}$ ed. São Paulo: Saraiva, 2004. p. 2.
} 
positivo. Ele questiona o fato de a própria Constituição fazer depender algumas questões de legislação ulterior. Assim:

\begin{abstract}
Por regra, as normas que consubstanciam os direitos fundamentais democráticos e individuais são de eficácia contida e aplicabilidade imediata, enquanto as que definem os direitos econômicos e sociais tentem a sê-lo também na Constituição vigente, mas algumas, especialmente as que mencionam uma lei integradora, são de eficácia limitada, de princípios programáticos e de aplicabilidade indireta, mas são tão jurídicas como as outras e exercem relevante função, porque, quanto mais se aperfeiçoam e adquirem eficácia mais ampla, mais se tornam garantias da democracia e do efetivo exercício dos demais direitos fundamentais ${ }^{23}$.
\end{abstract}

\title{
1.4 As Características e Classificações dos Direitos Fundamentais
}

Os Direitos Fundamentais possuem certas características que devem ser observadas para que a sua proteção e desenvolvimento sejam plenos. Há, na doutrina, diversos autores que potencializam essas características, dentre as quais estão em posição de destaque a historicidade, inalienabilidade, imprescritibilidade, irrenunciabilidade, universalidade e a relatividade.

Como visto no início, os Direitos Fundamentais foram surgindo e progredindo ao longo de uma construção histórica, que se perpetuou ao longo dos anos por meio de revoluções e até os dias atuais continuam em um estado de evolução. José Afonso da Silva ${ }^{24}$ afirma que são direitos que "nascem, modificam-se e desaparecem". Segundo o autor, eles "ampliam-se com o correr dos tempos".

O segundo caractere que permeia esses direitos encontra respaldo no aspecto da inalienabilidade, "são direitos intransferíveis, inegociáveis, porque não são de conteúdo econômico-patrimonial”.

A imprescritibilidade, como um terceiro aspecto, significa dizer que os Direitos Fundamentais não podem ser atingidos pelo instituto da

\footnotetext{
${ }^{23}$ SILVA, 2013, p. 182.
}

${ }^{24}$ SILVA, 2013, p. 183. 
prescrição, ou seja, nunca deixam de ser exigidos. De acordo com José Afonso da Silva:

A prescrição é um instituto jurídico que somente atinge, coarctando, a exigibilidade dos direitos de caráter patrimonial, não a exigibilidade de direitos personalíssimos, ainda que não individualistas, como é o caso. Se são sempre exercíveis e exercidos, não há intercorrência temporal de não exercício que fundamente a perda da exigibilidade pela prescrição ${ }^{25}$.

A irrenunciabilidade é a quarta característica que transpassa os Direitos Fundamentais. Significa dizer que não se pode renunciar a eles, tendo em conta que a sua natureza é protetiva e se assenta na dignidade da pessoa humana.

Os Direitos Fundamentais também são considerados universais, haja vista que o seu alcance atinge a todos. Entretanto, é relevante explicitar, que o ministro Gilmar Mendes e outros doutrinadores afirmam que essa característica não é aplicável a todos os direitos:

\begin{abstract}
Não é impróprio afirmar que todas as pessoas são titulares de direitos fundamentais e que a qualidade de ser humano constitui condição suficiente para a titularidade de tantos desses direitos. Alguns direitos fundamentais específicos, porém, não se ligam a toda e qualquer pessoa. Na lista brasileira dos direitos fundamentais, há direitos de todos os homens - como o direito à vida -mas há também posições que não interessam a todos os indivíduos, referindo-se apenas a alguns - aos trabalhadores, por exemplo ${ }^{26}$.
\end{abstract}

É impreterível ressaltar que é o caráter relativo dos Direitos Fundamentais que permite a resolução de possíveis conflitos advindos do "choque" entre direitos distintos. A partir de uma divergência em um caso concreto, é possível vislumbrar que eles não são absolutos. Dessa forma, a melhor maneira para solucionar o conflito é aplicar os critérios da proporcionalidade e ponderação ${ }^{27}$, para que assim seja possível definir,

\footnotetext{
${ }^{25}$ Ibid., p. 183.

${ }^{26}$ MENDES, Gilmar Ferreira et al. Curso de direito constitucional. $3^{\mathrm{a}}$ ed. rev. atual. São Paulo: Saraiva, 2008. p. 240.

27 Em relação ao princípio da proporcionalidade, pode-se dizer que ele é dividido em três subprincípios: adequação, necessidade e proporcionalidade stricto sensu. $\mathrm{O}$ da adequação significa que é preciso existir uma conexão entre o meio e o fim, ou seja, os meios empregados devem ser adequados para atingir um fim específico. $\mathrm{O}$ da necessidade corresponde a indispensabilidade em
} 
como ensina Canotilho, o quanto de restrição e o quanto de observância pode haver numa harmonização. O próprio STF já se posicionou a respeito do tema e afirmou que "os direitos e as garantias individuais não têm caráter absoluto"28.

Após delinear de forma simplificada as características mais eminentes, é preciso arrolar o estudo referente às classificações dos Direitos Fundamentais. José Afonso da Silva consagra o tema com clareza e manifesta que, para esta atividade, é preciso ter como referência um determinado ordenamento jurídico e sua ótica constitucional.

A primeira classificação feita retrata a divisão por meio de três fontes dos direitos e garantias. Podem ser expressos, decorrentes dos princípios e regime adotados pela Constituição e provenientes de Tratados e Convenções internacionais adotados e incorporados pelo sistema normativo jurídico brasileiro.

José Afonso da Silva também divide e relaciona os Direitos Fundamentais por meio do seu conteúdo. Dessa maneira, existem "direitos fundamentais do homem-indivíduo", que são reconhecidos como direitos individuais e denominados ainda como "liberdades civis" e "liberdadesautonomia". "São aqueles que reconhecem a autonomia aos particulares, garantindo a iniciativa e independência aos indivíduos diante dos demais membros da sociedade política e do próprio Estado" 29.

Ademais, é possível vislumbrar, segundo o autor, "direitos fundamentais do homem nacional", "que tem por conteúdo e objeto a definição da nacionalidade e suas faculdades”. Além disso, existem aqueles

adotar uma determinada medida. E o da proporcionalidade stricto sensu é aquele que precisa ser severamente observado quando houver um conflito entre direitos fundamentais, isto é, o julgador deverá estabelecer critérios e soluções que sejam mais benéficos para as partes envolvidas num determinado caso concreto. O critério da ponderação guarda relação com o princípio da proporcionalidade, pois é uma técnica que auxilia na decisão dos casos difíceis. Nos moldes de Ana Paula de Barcellos: “A ponderação é a técnica jurídica de solução de conflitos normativos que envolvem valores ou opções políticas em tensão, insuperáveis pelas formas hermenêuticas tradicionais". BARCELLOS, Ana Paula. Ponderação, Racionalidade e Atividade Jurisdicional. $1^{\text {a }}$ ed. São Paulo: Renovar, 2005. p. 23.

${ }^{28}$ STF, MS 23.452, Rel. Ministro Celso de Mello, Rio de Janeiro, 12 mai. 2000. p. 20.

${ }^{29}$ SILVA, 2013, p. 193. 
direitos consagrados como "direitos fundamentais do homem-cidadão", que são os direitos políticos, democráticos e de participação política.

A quarta forma de separar esses Direitos Fundamentais através do critério do conteúdo é denominando-os como "direitos fundamentais do homem-social", que são os direitos assegurados ao homem em suas relações sociais e culturais.

São prestações positivas proporcionadas pelo Estado direta ou indiretamente, enunciadas em normas constitucionais, que possibilitam melhores condições de vida aos mais fracos, direitos que tendem a realizar a igualização de situações sociais desiguais. São, portanto, direitos que se ligam ao direito de igualdade ${ }^{30}$.

Os "direitos fundamentais do homem-membro de uma coletividade" também é outra classificação empregada por José Afonso da Silva. Vale dizer que a Constituição Federal Brasileira adotou essa categoria como "direitos-coletivos".

E, por último, existe a classe dos direitos fundamentais respaldados no "homem-solidário", isto é, direitos do gênero humano, considerados como os de "terceira geração".

Com isso, é possível, com base na Constituição Brasileira, classificar os direitos fundamentais em seis grupos distintos: direitos individuais, direitos à nacionalidade, direitos políticos, direitos sociais, direitos coletivos e direitos solidários.

\subsection{O Princípio do Acesso à Justiça como Instrumento Primário dos Direitos Fundamentais}

É de primordial importância abordar aqui o princípio do acesso à justiça, denominado também como o princípio da inafastabilidade do controle jurisdicional ou princípio do direito de ação.

\footnotetext{
${ }^{30}$ Ibid., p. 288-289.
} 
Primeiramente, devemos reconhecer que, dentro de uma sociedade, existem inúmeros conflitos entre as pessoas e que estes precisam ser solucionados. Estas divergências se propagam pela própria natureza humana, tendo em vista que as pessoas pensam de forma distinta e possuem interesses opostos.

Dessa forma, surge o Direito como um meio de reintegrar, organizar e disciplinar prerrogativas e deveres para todos, de modo a garantir uma harmonização no convívio social entre os indivíduos. Assim, fica nítido que o próprio Direito nasce e encontra-se inserido na sociedade, sendo, fruto das relações sociais.

Sabe-se que, a existência de um Poder Judiciário atuante foi uma das grandes conquistas da civilização, pois antes não havia a presença operante do Estado em dizer e aplicar o Direito. Dessa forma, o Judiciário passa a ter como responsabilidade a tutela e o estabelecimento de medidas satisfatórias para os diversos casos concretos.

Em um primeiro momento, a principal forma de resolver os problemas que surgiam entre as pessoas era através da autotutela. As pessoas utilizavam a própria força para alcançar a pretensão desejada. Este método demonstrou-se ao longo dos anos como insatisfatório e injusto, pois aqueles que detinham a maior força eram os que sempre saíam vencedores da disputa. Desta maneira, fica claro que não havia um caráter de justiça impregnado nesta resolução de divergências.

Depois disso, com o ensejo e fortalecimento do Estado de Direito, o Estado retoma ao posto que the foi tirado e se afirma como aquele que tem a capacidade de deliberar, auxiliar e promover direitos para a coletividade. Neste sentido, surge o Estado-juiz com o monopólio da jurisdição, assumindo a competência para dirimir conflitos, julgá-los e solucioná-los aplicando o Direito positivado, princípios e parâmetros de equidade e justiça. Surge assim, a ideia de uma pacificação social tendo como escopo uma justiça social e igualitária. 
Entretanto, este ideal de uma assistência jurídica igualitária não foi perpetuado ao longo do tempo. É possível constatar a disparidade do acesso à justiça no Brasil, por exemplo, desde o período colonial, no qual apenas uma parcela da população não possuía restrição a este ingresso. Como observa Mauro Cappelletti, ao referir-se a situações como esta, "O Estado, portanto, permanecia passivo, com relação a problemas tais como a aptidão de uma pessoa para reconhecer seus direitos e defendê-los adequadamente, na prática" 31 .

E continua:

A justiça, como outros bens, no sistema do laissez-faire, só podia ser obtida por aqueles que pudessem enfrentar seus custos; aqueles que não pudessem fazê-lo eram considerados os únicos responsáveis por sua sorte. $\mathrm{O}$ acesso formal, mas não efetivo à justiça, correspondia à igualdade, apenas formal, mas não efetiva ${ }^{32}$.

É possível perceber, então, que havia uma visão individualista entranhada, consequência do liberalismo econômico da época. A partir do momento em que as ações e relações humanas assumiram um caráter mais coletivo que individual, as sociedades modernas necessariamente deixaram para trás a visão individualista. Isso ocorreu também por conta da grande evolução que ocorria em prol da tutela dos direitos humanos, que começavam a ser reconhecidos nas Constituições e nas Convenções Internacionais, tornando, assim, a atuação estatal mais positiva e efetiva, no sentido de assegurar o gozo de todos os direitos básicos e sociais.

\section{Ainda Cappelletti:}

O direito ao acesso efetivo tem sido progressivamente reconhecido como sendo de importância capital entre os novos direitos individuais e sociais, uma vez que a titularidade de direitos é destituída de sentido, na ausência de mecanismos para sua efetiva reivindicação. $\mathrm{O}$ acesso à justiça pode, portanto, ser encarado como o requisito fundamental - o mais básico dos direitos humanos - de um sistema

\footnotetext{
31 CAPPELlETTI, Mauro; GARTH, Bryan. Acesso à Justiça. NORTHFLEET, Ellen Gracie (Trad.). Porto Alegre: Fabris Editora, 1988. p. 9.

${ }^{32}$ Ibid., p. 9.
} 
jurídico moderno e igualitário que pretenda garantir, e não apenas proclamar os direitos de $\operatorname{todos}^{33}$.

Kazuo Watanabe defende que: "a problemática do acesso à justiça não pode ser estudada nos acanhados limites dos órgãos judiciais já existentes. Não se trata apenas de possibilitar o acesso à justiça enquanto instituição estatal, e sim de viabilizar o acesso à ordem jurídica justa" ${ }^{34}$.

Boaventura de Sousa Santos, por sua vez, afirma que:

Por um lado, a consagração constitucional dos novos direitos econômicos e sociais e a sua expansão paralela à do Estado de bem estar transformou o direito ao acesso efetivo à justiça num direito charneira, um direito cuja denegação acarretaria a de todos os demais. Uma vez destituídos de mecanismos que fizessem impor o seu respeito, os novos direitos sociais e econômicos passariam a meras declarações políticas, de conteúdo e de função mistificadores. Daí a constatação de que a organização da justiça civil e, em particular, a tramitação processual não podiam ser reduzidas à sua dimensão técnica, socialmente neutra, como era comum serrem concebidas pela teoria processualista, devendo investigar-se as funções sociais por elas desempenhadas e em particular o modo como as opções técnicas no seu seio veiculavam opções a favor ou contra interesses sociais divergentes ou mesmo antagônicos ${ }^{35}$.

$\mathrm{O}$ acesso à justiça deve ser pensado com uma perspectiva de cunho social, paritário, cidadão, trazendo a ideia de uma justiça social. Com isso, é possível afirmar que este acesso não está pautado apenas no ingresso ao poder judiciário, mas também na busca de uma solução eficiente, ampla, traçada também no âmbito da consultoria, da orientação jurídica e da atividade extrajudicial.

Como foi observado, o acesso à justiça nunca foi visto como um princípio inerente a todos. Existem muitas limitações que vão além das dissemelhantes classes sociais. A título de exemplo, um dos grandes problemas que assolam a garantia deste princípio é a dificuldade

\footnotetext{
33. CAPPELLETTI; GARTH, 1988, p. 11-12.

${ }^{34}$ WATANABE, Kazuo et al.. Acesso à Justiça e Sociedade Moderna In: Participação e Processo. São Paulo: RT Editora, 1988. p. 128.

35 SANTOS, Boaventura de Sousa. Introdução à Sociologia da Administração da Justiça In: Revista Crítica de Ciências Sociais. no 21, nov. 1986. p. 18.
} 
econômica. Todavia, além dos obstáculos financeiros, há também uma forte limitação em relação aos aspectos sociais e culturais.

Boaventura de Sousa Santos relacionou a sociologia com a administração da justiça, o que possibilitou a percepção dos maiores enfoques e entraves que permeiam e dificultam o acesso à justiça, ressaltando que os principais obstáculos são realmente os citados acima: econômicos, sociais e culturais.

Quanto aos problemas econômicos, verifica-se nas sociedades capitalistas os altos custos dos processos, de modo que, muitas vezes, acabam sendo superiores ao próprio valor da causa. Dessa forma, a justiça é considerada como dispendiosa e proporcionalmente injusta para os cidadãos economicamente mais frágeis. Além das custas, Boaventura também percebeu que a lentidão dos processos é outra limitação que deve ser observada e que pode acarretar numa despesa econômica adicional.

O professor Boaventura de Sousa Santos constatou conjuntamente que há inovações no processo que precisam de um reconhecimento, mas apesar delas, com a sociologia judiciária percebe-se que é preciso tomar em conta e submeter a análise sistemática a outros fatores importantes.

Segundo o autor:

Estudos revelam que a distância dos cidadãos em relação à administração da justiça é tanto maior quanto mais baixo é o estrato social a que pertencem e que essa distância tem como causas próximas não apenas fatores econômicos, mas também fatores sociais e culturais, ainda que uns e outros possam estar mais ou menos remotamente relacionados com as desigualdades econômicas. Em primeiro lugar, os cidadãos de menores recursos tendem a conhecer pior os seus direitos e, portanto, a ter mais dificuldades em reconhecer um problema que os afeta como sendo problema jurídico (...). Em segundo lugar, mesmo reconhecendo o problema como jurídico, como violação de um direito, é necessário que a pessoa se disponha a interpor a ação. Os dados mostram que os indivíduos das classes baixas hesitam muito mais que os outros em recorrer aos tribunais, mesmo quando reconhecem estar perante um problema legal (...). Em terceiro e último lugar, verifica-se que o reconhecimento do problema como problema jurídico e o desejo de recorrer aos tribunais para o resolver não são suficientes para que a iniciativa seja de fato tomada. Quanto mais baixo é o estrato socioeconômico do cidadão menos provável é que conheça advogado ou que tenha amigos que conheçam advogados, menos provável é que saiba onde e como e quando pode contatar o advogado e maior é a distancia geográfica entre o lugar onde vive ou 
trabalha e a zona da cidade onde se encontram os escritórios de advocacia e os tribunais" $"$.

Dessa forma, a conclusão que Boaventura de Sousa Santos expõe é baseada na existência de uma forte discriminação social no acesso à justiça, que à primeira vista pode mostrar apenas limitações econômicas, porém envolve, também, como visto, condicionantes sociais e culturais.

Nesse contexto dos impedimentos que abrangem o acesso à justiça, é imprescindível citar aqui o jurista italiano Mauro Cappelletti, que, em sua obra "Acesso à Justiça", realizou uma análise dos diversos sistemas jurídicos existentes no mundo e apresentou propostas, por ele denominadas “ondas" desenvolvidas ao longo do tempo:

Podemos afirmar que a primeira solução para o acesso - a primeira "onda" desse movimento novo - foi a assistência judiciária; a segunda dizia respeito à reformas tendentes a proporcionar representação jurídica para os interesses "difusos", especialmente nas áreas da proteção ambiental e do consumidor; e o terceiro - e mais recente - é o que nos propomos a chamar simplesmente "enfoque do acesso à justiça porque inclui os posicionamentos anteriores, mas vai muito além deles, representando, dessa forma, uma tentativa de atacar as barreiras ao acesso de modo mais articulado e compreensivo ${ }^{37}$.

"Os primeiros esforços importantes para incrementar o acesso à justiça nos países ocidentais concentram-se, muito adequadamente, em proporcionar serviços jurídicos aos pobres" ${ }^{38}$. A partir desse enfoque, a primeira onda foi baseada na assistência judiciária aos mais carentes que sempre foi muito precária e insuficiente.

A primeira forma que surgiu para tentar erradicar o problema foi o sistema chamado de "Judicare":

Trata-se de um sistema através do qual a assistência judiciaria é estabelecida como um direito para todas as pessoas que se enquadrem nos termos da lei, os advogados particulares, então, são pagos pelo Estado. A finalidade do sistema

\footnotetext{
${ }^{36}$ SANTOS, 1986, p. $28-29$.

${ }^{37}$ CAPPELLETTI; GARTH, 1988, p. 31.

${ }^{38}$ Ibid., p. 31.
} 
judicare é proporcionar aos litigantes de baixa renda a mesma representação que teriam se pudessem pagar um advogado ${ }^{39}$.

Entretanto, esse primeiro sistema encontrou diversas dificuldades. Por conta disso, surgiu um segundo mecanismo, o do "advogado remunerado pelos cofres públicos”. "Os serviços jurídicos deveriam ser prestados por "escritórios de vizinhança", atendidos por advogados pagos pelo governo e encarregados de promover os interesses dos pobres, enquanto classe" aos pobres para auxiliá-los a reivindicar seus direitos e, cria uma categoria de advogados eficientes para atuar pelos pobres, enquanto classe" ${ }^{41}$.

Contudo, esse sistema também encontrou desdobramentos que continuavam dificultando o acesso à justiça. Um deles se relacionava ao fato de que havia uma dependência do apoio governamental para atividades de natureza política, isto é, para aquelas ações que eram propostas contra o próprio governo. Mauro Cappelletti esclarece:

\begin{abstract}
A solução de manter equipes de advogados assalariados, se não for combinada com outras soluções, é também limitada em sua utilidade pelo de que - ao contrário do sistema judicare, o qual utiliza a advocacia privada - ela não pode garantir o auxílio jurídico como um direito. Para sermos realistas, não é possível manter advogados em número suficiente para dar atendimento individual de primeira categoria a todos os pobres com problemas jurídicos. Por outro lado, e não menos importante, é o fato de que não pode haver advogados suficientes para estender a assistência judiciária à classe média, um desenvolvimento que é um traço distintivo fundamental da maior parte dos sistemas judicare ${ }^{42}$.
\end{abstract}

O terceiro sistema que surge é o de "modelos combinados". Este sistema parte do pressuposto de que em alguns países é possível perceber a combinação dos dois modelos citados acima. A Suécia e a Província Canadense de Quebeque são dois exemplos.

Este modelo combinado permite que os indivíduos escolham entre os serviços personalizados de um advogado particular e a capacitação especial dos advogados

\footnotetext{
${ }^{39}$ CAPPELLETTI; GARTH, 1988, p. 35.

${ }^{40}$ Ibid., p. 39-40.

${ }^{41}$ Ibid., p. 41.

${ }^{42}$ Ibid., p. 42-43.
} 
de equipe, mais sintonizados com os problemas dos pobres. Dessa forma, tanto as pessoas menos favorecidas, quanto os pobres como grupo, podem ser beneficiados ${ }^{43}$.

Apesar de todos os sistemas instituídos, o autor percebeu que em relação à proteção dos interesses difusos, tais como os dos consumidores ou dos defensores do meio ambiente ainda existia uma grande deficiência. A partir disso, surge a segunda onda vislumbrada por Mauro Cappelletti.

É observado pelo autor italiano que a ação governamental é um dos principais métodos para a realização dos interesses difusos. Entretanto, não tem sido bem-sucedida aos seus olhos. "É preciso acrescentar a energia e o zelo particulares à máquina burocrática, a qual, muito amiúde, torna-se lenta, inflexível e passiva na execução de suas tarefas" ${ }^{4}$.

Ainda na segunda onda, esses interesses difusos, segundo assevera Mauro Cappelletti:

Exigem uma eficiente ação de grupos particulares, sempre que possível; mas grupos particulares nem sempre estão disponíveis e costumam ser difíceis de organizar. A combinação de recursos, tais como as ações coletivas, as sociedades de advogados do interesse público, a assessoria pública e o advogado público podem auxiliar a superar este problema e conduzir à reivindicação eficiente dos interesses difusos ${ }^{45}$.

A terceira onda, de acordo com Mauro Cappelletti:

Inclui a advocacia, judicial ou extrajudicial, seja por meio de advogados particulares ou públicos, mas vai além. Ela centra sua atenção no conjunto geral de instituições e mecanismos, pessoas e procedimentos utilizados para processar e mesmo prevenir disputas nas sociedades modernas (...). Seu método não consiste em abandonar as técnicas das duas primeiras ondas de reforma, mas em tratá-las como apenas algumas de uma série de possibilidades para melhorar o acesso ${ }^{46}$.

Nesse sentido:

\footnotetext{
${ }^{43}$ CAPPELLETTI; GARTH, 1988, p. 44.

${ }^{44}$ Ibid., p. 55.

${ }^{45}$ Ibid., p. 66-67.

${ }^{46}$ Ibid., p. 67-68.
} 
(...) esse enfoque encoraja a exploração de uma ampla variedade de reformas, incluindo alterações nas formas de procedimento, mudanças na estrutura dos tribunais ou a criação de novos tribunais, o uso de pessoas leigas ou paraprofissionais, tanto como juízes quanto como defensores, modificações no direito substantivo destinadas a evitar litígios ou facilitar sua solução e a utilização de mecanismos privados ou informais de solução dos litígios. Esse enfoque, em suma, não receia inovações radicais e compreensivas, que vão muito além da esfera de representação judicial. Ademais, esse enfoque reconhece a necessidade de correlacionar e adaptar o processo civil ao tipo de litígio ${ }^{47}$.

Após a abordagem das três ondas compreendidas por Mauro Cappelletti, é importante citar também o autor Kim Economides, que, a partir de seus estudos, percebeu a existência de uma quarta onda, evidenciando que "o acesso dos cidadãos à justiça é inútil sem o acesso dos operadores do direito à justiça." ${ }^{48}$. Dessa forma, Economides institui a quarta onda pautada no acesso dos operadores do direito à justiça.

Um dos primeiros pontos mencionados é o do "acesso à educação jurídica", isto é, deveria haver, segundo ele, uma preocupação com as faculdades de Direito que são instituídas e com o ensino jurídico empregado por cada uma delas. Além disso, o autor defende que é necessário que os organismos profissionais e os advogados promovam positivamente o acesso à profissão legal de mulheres, minorias e de grupos em desvantagem.

O segundo ponto consagrado por Economides diz respeito ao acesso à justiça por parte de juízes e advogados. Com isso, pode-se dizer, que há um desdobramento ético em relação às responsabilidades das faculdades de direito e dos organismos profissionais de forma a serem mais amplas e efetivas.

Depois dessa abordagem de como o acesso à justiça é visto por esses autores, é imperioso citar a forma pela qual este princípio está inserido no Ordenamento Jurídico Brasileiro e sua importância na defesa e no amparo dos direitos fundamentais.

\footnotetext{
${ }^{47}$ CAPPELLETTI; GARTH, 1988, p. 71.

48 ECONOMIDES, Kim. Lendo as Ondas do "Movimento do Acesso à Justiça": Epistemologia versus Metodologia?. p. 62. Disponível em: <http://www.comunidadesegura.org.br/files/lendoasondasdomovimentodeacessoajusticaepistemol ogiaversusmetodologiakimeconomides.pdf>. Acesso em: 01 nov. 2017.
} 
Desde a Convenção Interamericana de Direitos Humanos de 1969, o Pacto de San José da Costa Rica, do qual o Brasil é signatário, fica fácil perceber a relevância que o acesso à justiça possui:

Toda pessoa tem direito de ser ouvida, com as devidas garantias e dentro de um prazo razoável, por um juiz ou tribunal competente, independente e imparcial, estabelecido anteriormente por lei, na apuração de qualquer acusação penal contra ela, ou para que se determinem seus direitos ou obrigações de natureza civil, trabalhista, fiscal ou de qualquer natureza" (Artigo $8^{\circ}$, 1, da Convenção Interamericana sobre Direitos Humanos - São José da Costa Rica) ${ }^{49}$.

\section{A Constituição Federal Brasileira de 1988 também preconiza o}

princípio da inafastabilidade da jurisdição em um de seus artigos:

Art. $5^{\circ}$ Todos são iguais perante a lei, sem distinção de qualquer natureza, garantindo-se aos brasileiros e aos estrangeiros residentes no País a inviolabilidade do direito à vida, à liberdade, à igualdade, à segurança e à propriedade, nos termos seguintes: XXXV - a lei não excluirá da apreciação do Poder Judiciário lesão ou ameaça a direito" 50 .

\section{É possível identificar que a Constituição assegura o acesso à justiça} de forma repressiva e preventiva, além de garantir esse princípio para todos, sem exceção.

\section{Alexandre de Moraes explicita:}

O Poder Judiciário, desde que haja plausibilidade de ameaça ao direito, é obrigado a efetivar o pedido de prestação judicial requerido pela parte de forma regular, pois a indeclinabilidade da prestação judicial é princípio básico que rege a jurisdição, uma vez que a toda violação de um direito responde uma ação correlativa, independentemente de lei especial que a outorgue ${ }^{51}$.

\footnotetext{
${ }^{49}$ Convenção Americana de Direitos Humanos. Pacto de San José da Costa Rica. Disponível em: <http://www.pge.sp.gov.br/centrodeestudos/bibliotecavirtual/instrumentos/sanjose.htm>. Acesso em: 05 nov. 2017.

${ }^{50}$ BRASIL. Constituição (1988). Disponível em:

<http://www.planalto.gov.br/ccivil_03/constituicao/constituicaocompilado.htm>. Acesso em: 05 nov. 2017.

${ }^{51}$ MORAES, Alexandre de. Direitos Humanos Fundamentais. Teoria Geral. Comentários aos arts. 10 à 5o da Constituição da República Federativa do Brasil. Doutrina e Jurisprudência. $2^{a}$ ed. São Paulo: Atlas S.A., 1998. p. 197.
} 
O acesso à justiça é indispensável para que os indivíduos tenham a oportunidade de defender suas prerrogativas e lutar para que elas sejam efetivadas da forma mais justa e adequada.

O Brasil é constituído por uma ordem jurídica democrática e é caracterizado como um Estado Democrático de Direito. Por conta disso, é inegável a magnitude que este princípio apresenta, tendo em vista que, é a partir dele que surge a possibilidade dos cidadãos usufruírem dos demais direitos fundamentais, de maneira que eles não sejam apenas positivados e não garantidos.

Com isso, é por meio do acesso à justiça que é possível realizar a proteção necessária para abarcar os direitos fundamentais consagrados na Constituição Federal e nos Tratados e Convenções incorporados ao ordenamento jurídico brasileiro. Hilary Sommerlad diz que sem o direito de acesso à justiça os demais direitos são essencialmente ilusórios ${ }^{52}$. Seguindo essa mesma linha, Maria Tereza Aina Sadek observa que o acesso à justiça é o direito primeiro, ou seja, é o direito garantidor dos demais direitos. Sem ele todos os demais serão apenas ideais que não se concretizam ${ }^{53}$.

Cançado Trindade expressa tal entendimento de forma clara:

O direito do acesso à justiça, dotado de conteúdo jurídico próprio, significa, lato sensu, o direito de obter justiça. Configura-se, assim, em suma, como o direito da própria realização da justiça. Um dos componentes principais deste direito é precisamente o acesso direto a um tribunal competente, mediante um recurso efetivo e rápido, e o direito a ser prontamente ouvido pelo referido tribunal, independentemente e imparcialmente, a níveis tanto nacional como internacional (artigos 25 e 8 da Convenção Americana). Como me permiti assinalar em uma obra recente, podemos aqui visualizar um verdadeiro direito ao direito, ou seja, o direito a um ordenamento jurídico - a níveis tanto nacional como internacional que efetivamente salvaguarde os direitos fundamentais da pessoa humana ${ }^{54}$.

\footnotetext{
52 SOMMERLAD, Hilary. Some Reflections on the relationship between citizenship, access to justice, and the reform os legal aid, In: Journal os Law and Society, v. 31, no. 3, September, 2004. p. 362.

53 SADEK, Maria Tereza Aina. Defensoria Pública: Conquista da Cidadania, In: RÉ, Aluísio Iunes Monti Ruggeri. Temas Aprofundados da Defensoria Pública, Bahia: Jus Podivm, 2013. p. 20.

${ }^{54}$ Tradução livre da passagem do voto de A.A. Cançado Trindade, ex-juiz da Corte Interamericana de Direitos Humanos, no julgamento do Caso Damião Ximenez Lopes versus Brasil. O trecho refere-se à citação feita pelo próprio Cançado Trindade em outro voto anterior no julgamento do
} 
Com base nesta perspectiva, é plausível afirmar que sem o acesso à justiça, os direitos fundamentais não teriam como ser garantidos, tutelados e atingidos. É por meio deste princípio que as prerrogativas conferidas na Constituição são alcançadas.

Luiz Guilherme Marinoni ressalta:

O Direito de acesso à justiça não é apenas necessário para viabilizar a tutela dos demais direitos, como imprescindível para uma organização justa e democrática. Não há democracia em um Estado incapaz de garantir o acesso à justiça ${ }^{55}$.

O acesso à justiça é o principal instrumento capaz de viabilizar a efetividade dos direitos que são inerentes à pessoa humana. Dessa forma, fica fácil observar que, sem o acesso à justiça, torna-se impossível alcançar um dos fundamentos consagrados no Texto Constitucional, a dignidade da pessoa humana.

Vale ressaltar que o princípio da inafastabilidade da jurisdição não protege apenas o ingresso do cidadão ao poder judiciário, ele vai muito além disto. Ele é compreendido sob uma ótica de assistência jurídica, visto que não tutela apenas a forma pela qual o indivíduo consegue chegar ao Estado-juiz, mas também abarca a consultoria jurídica; o assessoramento; a atividade extrajudicial; o exercício dos juízes no seu ofício para que as sentenças sejam adequadas e fundamentadas, regidas pelos princípios da proporcionalidade e razoabilidade; é através dele que é possível também amparar uma maior informalidade no processo, tendo em vista que há um forte rigor técnico e formalista, além dos brocardos frequentemente utilizados, de difícil compreensão para aqueles considerados leigos.

caso Massacre de Pueblo Bello versus Colômbia (sentença de 31.01.2006), no qual foi sustentada a tese da indissociabilidade entre os artigos 8 e 25 da Convenção Americana como um "avanço jurisprudencial intangível" (pars.4452).

Disponível em: <http://www.corteidh.or.cr/docs/casos/articulos/seriec_149_por.pdf>. Acesso em: 25 set. 2015. A obra de sua autoria a que o autor se refere na passagem citada é:

TRINDADE, A. A. Cançado. Tratado de Direito Internacional dos Direitos Humanos. t. III, Porto Alegre: Fabris, 2002. p. 524.

55 MARINONI, Luiz Guilherme. Teoria Geral do Processo. São Paulo: Revista dos Tribunais, 2006. p. 462-463. 
Com base nisto, é plausível pensar que se a autotutela é proibida nos dias atuais, o Estado que detém o monopólio da jurisdição tem como obrigação a promoção de meios eficazes para que o acesso à justiça seja justo, abrangente e efetivo, de forma a ampará-lo e a fornecer uma assistência jurídica igualitária, que é intrínseca a ele.

Contudo, como foi abordado acima, existem inúmeros fatores que impedem a amplitude deste acesso. Pensando nisso, a Constituição Federal prevê em seu artigo $5^{\circ}$ :

LXXIV - o Estado prestará assistência jurídica integral e gratuita aos que comprovarem insuficiência de recursos ${ }^{56}$.

Dessa maneira, consagra-se a Defensoria Pública como um agente fundamental e imprescindível ao acesso à justiça. Esta temática será abordada de forma mais densa ao longo da Monografia, bem como os entraves que estão inseridos na própria instituição e fora dela.

\footnotetext{
${ }^{56}$ BRASIL. Constituição (1988). Acesso em: 05 nov. 2017.
} 


\section{CAPÍTULO 2 - A DEFENSORIA PÚBLICA}

\subsection{Histórico da Instituição da Defensoria Pública no Brasil e a Assistência Jurídica Integral}

Ao longo da evolução histórica é possível analisar e perceber como foi dado o impulso e como surgiu a Defensoria Pública no Brasil.

O fornecimento de condições aos menos favorecidos para que eles possam lutar e alcançar os seus direitos é uma das obrigações primordiais do Estado. E isso seria impossível sem o devido acesso à justiça realizado de forma gratuita, adequada e satisfatória.

O Brasil passou por períodos distintos e por diversas legislações que foram modificando a prestação da assistência judiciária até tornar-se uma assistência jurídica, abarcando e tutelando outros direitos, que não apenas o direito de postular no poder judiciário. Sem dúvida, a Constituição da República Federativa do Brasil de 1988 exerceu um papel fundamental nesta seara com a instituição da Defensoria Pública, pois permitiu que esta, com exclusividade, exercesse a defesa dos mais necessitados, tanto no âmbito judicial como no extrajudicial.

No estado brasileiro, a assistência gratuita tem sua origem nas Ordenações Filipinas, de 1595, de Portugal. Cleber Francisco Alves ensina que "desde o início da colonização portuguesa a defesa das pessoas pobres perante os tribunais era considerada uma obra de caridade, com fortes traços religiosos" ${ }^{57}$. Além disso, foi importado do direito português "a praxe do advogado patrocinar gratuitamente os miseráveis e os indefesos que procurassem o juízo tanto nas causas cíveis quanto nas criminais"s8.

\footnotetext{
57 ALVES, Cléber Francisco. Justiça para todos! Assistência Gratuita nos Estados Unidos, na França e no Brasi. Rio de Janeiro: Lumen Juris, 2006. p. 237.

${ }^{58}$ ROCHA, Jorge Luís. História da Defensoria Pública e da Associação dos Defensores Públicos do Estado do Rio de Janeiro. Rio de Janeiro: Lumen Juris, 2004. p. 124.
} 
Celso Ribeiro Bastos diz:

No Brasil, a assistência judiciária tem suas raízes nas Ordenações Filipinas. Esse diploma foi muito importante na história do Brasil porque, por força da Lei de 20 de outubro de 1823, vigorou por estas terras até 1916. Com o passar dos anos, a incumbência vai gradativamente recaindo nos ombros dos advogados, coisa que não era estranha às ideias reinantes, de há muito, nas corporações de causídicos ${ }^{59}$.

Depois disso, surgiram algumas leis, como a Lei no 261 , de 1841, que alterou o Código de Processo Penal do Império de 1832. Entretanto, a assistência jurídica gratuita era prestada pelos advogados apenas de forma caridosa e benevolente, não havia a mínima preocupação com a qualidade dessa assessoria ${ }^{60}$.

Em 1870, o presidente do Instituto dos Advogados Brasileiros, José Tomás Nabuco de Araújo, sugeriu que a entidade assumisse a responsabilidade de prestar consultoria jurídica e de oferecer defesa às pessoas pobres em juízo ${ }^{61}$. Cleber Francisco Alves destaca:

O próprio Nabuco de Araújo tinha plena consciência da relevância e importância do programa que estava implementando, e de que não bastava agir por impulso de caridade, como era a praxe até então, mas que era preciso estabelecer em lei a garantia do acesso dos pobres aos tribunais ${ }^{62}$.

Apesar dos esforços do Instituto, o acesso à justiça continuou deficiente, isso porque as pessoas dependiam dos advogados que prestavam serviços de forma misericordiosa e porque não havia ainda uma legislação específica regulando o tema.

Para Cléber Francisco Alves, durante o período imperial, o poder público tomou a iniciativa de contratar e remunerar indivíduos capazes de exercer a defesa dos mais necessitados nos processos criminais. Essa contribuição para a sociedade foi tomada pela Câmara Municipal da Corte.

59 BASTOS, Celso Ribeiro Bastos. Comentários à Constituição do Brasil. v. 2. São Paulo: Saraiva, 1989. p. 374.

${ }^{60}$ ESTEVES, Diogo; ALVES SILVA, Franklyn Roger. Princípios Institucionais da Defensoria Pública. $2^{\mathrm{a}}$ ed. Rio de Janeiro: Forense, 2017. p. 48.

${ }^{61}$ Ibid., p. 49.

${ }^{62}$ ALVES, 2006, p. 239. 
Vale citar que, "esse teria sido o primeiro Defensor Público da história do Brasil", sendo o cargo extinto em $1884^{63}$.

Em 1889, o Brasil passava por um período de mudanças por conta da proclamação da República. Tal acontecimento fez surgir a necessidade de uma renovação no ordenamento jurídico brasileiro. No dia 14 de novembro de 1890, foi editado o Decreto $\mathrm{n}^{\mathrm{o}} 1.030$, que disciplinava a defesa dos pobres realizada por "curadores geraes", com a devida "requisição do presidente do Jury ou da câmara criminal" ${ }^{\prime}$. Por outro lado, em 1891 a primeira Constituição foi editada, porém, não abordava a temática da assistência jurídica gratuita, evidenciando assim, um grande retrocesso na esfera jurídica.

No ano de 1897, o Decreto $\mathrm{n}^{\mathrm{o}} 2.457$ estruturou a Assistência Judiciária do Distrito Federal (então cidade do Rio de Janeiro), com o objetivo de promover o "patrocínio gratuito aos pobres". É importante mencionar que este Decreto foi o primeiro modelo legalmente constituído com o intuito de organizar a prestação de assistência judiciária por meio de uma comissão seccional. Além disso, foi definido quem seriam os beneficiários da gratuidade de justiça e as suas devidas isenções. Por conta do sucesso que este modelo de assistência estava alcançando, a Justiça Federal passou a adotá-lo em 1910, bem como diversos Estados da federação passaram a implementar e a regulamentar a assistência judiciária.

Em 1934 foi promulgada nova Constituição Federal, com um cunho mais social, responsável por prever pela primeira vez a assistência judiciária no plano constitucional brasileiro. Em seu artigo 113, $\mathrm{n}^{\circ} 32$, o texto estabelece que a União e os Estados deveriam conceder aos necessitados assistência judiciária, e por conta disso, houve o surgimento de órgãos especiais, assim como a isenção de emolumentos, custas, taxas e selos. Percebe-se, dessa forma, que a Constituição priorizou a assistência judiciária, prevendo a criação de órgãos especiais com o propósito de

\footnotetext{
${ }^{63}$ ALVES, 2006, p. 240.

${ }^{64}$ ESTEVES, ALVES SILVA, 2017, p. 49-50.
} 
atender pessoas necessitadas e de modo especializado. Esse modelo ficou conhecido como "salaried staff model"65.

Cita-se, mais uma vez, Cleber Francisco Alves:

Ficou estabelecido como dever constitucional da União e dos Estados o de prestar a assistência judiciária aos necessitados, prevendo-se a criação de órgãos públicos que seriam especificamente encarregados de prestar tal serviço. Assim, a assistência judiciária deixava de ser um ônus legalmente imposto à classe dos advogados, passando a ser reconhecida como obrigação do poder público. Cabe lembrar que a Constituição brasileira de 1934, sob marcante influencia da Constituição de Weimar, pretendia expressar uma ruptura com o velho modelo do Estado de Direito liberal, buscando estruturar entre nós o novo paradigma de Estado Social que se difundia na Europa, atado politicamente às formas democráticas, mas voltado também para a efetivação de direitos sociais que emergiam no cenário histórico da época ${ }^{66}$.

O Estado de São Paulo, em 1935, juntamente com outros estados da federação, criou um "Departamento de Assistência Social", seguindo a ordem constitucional. Entretanto, isso foi apenas um projeto, pois a crise institucional da época era crescente. A Constituição de 1937, por outra parte, não previu qualquer direito para as pessoas menos favorecidas economicamente, reduzindo os direitos sociais, o que demonstrou grande retrocesso na ordem jurídica brasileira. A assistência judiciária gratuita, então, continuava sendo prestada de forma caritativa pelos advogados, de forma pro bono.

Após o governo de Getúlio Vargas, iniciou-se um período de redemocratização, o que influenciou na promulgação da Constituição de 1946, que repetiu a previsão constitucional anterior de 1934, reforçando que o Poder Público deveria conceder assistência judiciária. Porém, não havia um dispositivo que viabilizasse a assistência, ou seja, não existia a previsão de um órgão especial que efetivaria tal direito. Por conta dessa omissão, os Estados da federação criaram órgãos específicos de auxílio legal aos pobres. O Estado do Rio de Janeiro, por exemplo, estabeleceu que a assistência

\footnotetext{
${ }^{65}$ ESTEVES, ALVES SILVA, 2017, p. 51.

${ }^{66}$ ALVES, 2006, p. 243.
} 
judiciária gratuita seria prestada pelos integrantes da carreira inicial do Ministério Público.

No dia 5 de fevereiro, de 1950, foi editada a Lei $\mathrm{n}^{\circ}$ 1.060, responsável por regulamentar o direito à assistência judiciária. $\mathrm{O}$ artigo $2^{\circ}$, parágrafo único, disciplinava que, "todo aquele cuja situação econômica não the permita pagar as custas do processo e os honorários de advogado, sem prejuízo do sustento próprio ou da família" faria jus à assistência judiciária gratuita. Além disso, foi implementado um sistema misto de assistência judiciária, ou seja, o Poder Público deveria organizar e manter o serviço jurídico-assistencial, seguindo a temática do "salaried staff". Subsidiariamente, caso o serviço estatal não conseguisse se organizar, caberia aos advogados prestarem assistência em caráter pro bono. Tal lei foi tão importante que, em 1963, foi editado o Estatuto da Ordem dos Advogados do Brasil, instituindo como dever profissional dos advogados a prestação da assistência judiciária aos necessitados ${ }^{67}$.

Em 1967, a nova Constituição previu uma assistência judiciária como norma não autoaplicável, dependendo a sua regulamentação de leis infraconstitucionais. Em 1969 foi editada a Emenda no 1 à Constituição de 1967, entretanto, em relação à assistência judiciária não houve qualquer alteração redacional. Mais tarde, o entendimento que começou a ganhar impulso no Brasil foi o de que seria necessária a criação de órgãos governamentais e permanentes para amparar a camada popular mais carente, evitando, assim, buscar auxílio com advogados que atuavam de forma caridosa.

Na segunda metade da década de 1980, iniciou-se o processo de redemocratização do país; com isso, a Constituinte de 1987/1988 foi convocada e elaborou a Constituição da República Federativa do Brasil ${ }^{68}$. O texto constitucional foi promulgado no dia 5 de outubro de 1988, trazendo previsão expressa de qual seria o órgão responsável pela orientação jurídica

\footnotetext{
${ }^{67}$ ESTEVES, ALVES SILVA, 2017, p. 54.

${ }^{68}$ Ibid., p. 56.
} 
e defesa dos necessitados, a Defensoria Pública, um organismo governamental dotado de autonomia política e sem qualquer vínculo com as outras carreiras jurídicas, como aconteceu anteriormente. Assim, "a denominação de "Defensoria Pública" foi consagrada na Constituição Federal de 1988 para designar o órgão estatal encarregado privativamente de prestar assistência jurídica integral e gratuita aos necessitados" ${ }^{9}$.

Ademais, a assistência jurídica integral e gratuita foi consagrada como um direito fundamental e autoaplicável (art. 5, LXXIV). Vale mencionar que o texto constitucional não utilizou a expressão "assistência judiciária" como sempre era empregado, mas adotou o termo "assistência jurídica", uma noção mais ampla, preocupando-se não apenas com o acesso ao Poder Judiciário, mas também com a prestação extrajurisdicional.

Na lição de Cleber Francisco Alves, isso significa dizer que essa atividade passa a abranger a orientação e consultoria jurídicas, inclusive as de caráter preventivo, além de incluir o procuratório extrajudicial, quando necessário, e também a possibilidade de acessos aos meios alternativos de solução de conflitos, assim como a conscientização sobre os direitos da cidadania $^{70}$.

José Carlos Barbosa Moreira reafirma este entendimento:

A Constituição abandona aquela orientação restritiva de cuidar do assunto unicamente com referência à defesa em juízo; abandona a concepção de uma assistência puramente judiciária, e passa a falar em 'assistência jurídica integral'. Obviamente alarga de maneira notável o âmbito da assistência que passa a compreender, além da representação em juízo, além da defesa judicial, o aconselhamento, a consultoria, a informação jurídica e também a assistência aos carentes em matéria de atos jurídicos extrajudiciais, como por exemplo, os atos notariais e outros que conhecemos. Ora, essa inovação tem uma importância que não pode ser subestimada, porque justamente um dos fatores que mais contribuem para perpetuar as desigualdades nesse campo é, repito, a falta de informação. Acredito que haja uma enorme demanda reprimida de prestação jurisdicional, resultante da circunstância de que grande parcela, larga faixa da população do nosso país, pura e simplesmente, não tem qualquer informação sobre os seus direitos. Haverá também, do lado oposto, a vantagem consistente em, por meio da assessoria, do aconselhamento, prevenir certo número de litígios

\footnotetext{
${ }^{69}$ ALVES, 2006, p. 237.
}

${ }^{70}$ Ibid., p. 237. 
que só acabam por ser levados ao Judiciário exatamente em razão da pouca informação, em razão do desconhecimento, em razão da apreciação errônea que as pessoas fazem das suas próprias situações jurídicas ${ }^{71}$.

Ainda sobre o tema, Tiago Fensterseifer:

Em termos gerais, pode-se dizer que a assistência judiciária ou judicial está incorporada à assistência jurídica, que seria (esta última) um conceito mais amplo, uma vez que agrega também todo o espectro da atuação extrajudicial desempenha pela Defensoria Pública (orientação jurídica, educação em direitos, práticas extrajudiciais de resolução de conflitos, como mediação, conciliação, litigância estratégica etc.), tanto em sede da tutela e promoção de direitos individuais quanto, mais recentemente, também de direitos de natureza coletiva ${ }^{72}$.

\section{Sérvulo da Cunha enfatiza o entendimento:}

Ao se cogitar do acesso à justiça, o primeiro cuidado é com sua pseudojudicialidade. É impróprio o uso do termo justiça por judiciário. O judiciário está para a justiça assim como a rede hospitalar está para a saúde. A participação nos bens da vida e no conjunto dos bens sociais não se dá exclusivamente pela solução institucional dos conflitos, mas principalmente pelo exercício das liberdades fundamentais, dos poderes e funções que compõe a estrutura material da sociedade ${ }^{73}$.

A partir dessa evolução no conceito de assistência jurídica provocada pela criação da instituição, pode-se dizer que, "a Defensoria Pública é expressão desse novo paradigma jurídico social ou mesmo de um constitucionalismo social estabelecido pela Constituição de 1988."74. Ela é capaz de enaltecer e dar sentido ao Estado Democrático de Direito através do efetivo acesso à justiça, pois é através dela que as pessoas mais necessitadas terão a oportunidade de alcançarem justiça, dignidade e até mesmo uma maior participação na sociedade, parâmetros que são protegidos na ordem constitucional brasileira.

\footnotetext{
${ }^{71}$ BARBORA MOREIRA, José Carlos. O direito à assistência jurídica In: Revista de Direito da Defensoria Pública do Estado do Rio de Janeiro. Rio de Janeiro, ano 4, nº 5, 1991. p. 130.

72 FENSTERSEIFER, Tiago. Defensoria Pública na Constituição Federal. Rio de Janeiro: Forense, 2017. p. 64.

${ }^{73}$ CUNHA, Sérgio Sérvulo da. Fundamentos de direito constitucional. São Paulo: Saraiva, 2004. p. 187.

${ }^{74}$ FENSTERSEIFER, op. cit., p. 5.
} 


\subsection{Legislação Atual da Defensoria Pública no Brasil}

Para estudar com afinco a legitimidade da Defensoria Pública para defender os interesses e direitos das camadas mais carentes da população, preconizando o acesso à justiça, é imprescindível conhecer a sua legislação. Com isso, primeiramente, é necessário citar mais uma vez a Constituição da República Federativa do Brasil e o seu artigo 134. Este dispositivo é encontrado na Seção IV - destinada especificamente à Instituição - do Capítulo IV, que regula as funções essenciais à justiça no texto constitucional:

Art. 134 A Defensoria Pública é instituição permanente, essencial à função jurisdicional do Estado, incumbindo-lhe, como expressão e instrumento do regime democrático, fundamentalmente, a orientação jurídica, a promoção dos direitos humanos e a defesa, em todos os graus, judicial e extrajudicial, dos direitos individuais e coletivos, de forma integral e gratuita, aos necessitados, na forma do inciso LXXIV do art. $5^{\circ}$ desta Constituição Federal ${ }^{75}$.

Por meio deste artigo, é possível analisar o papel fundamental que a Defensoria Pública exerce em prol daqueles que não possuem condições econômicas, culturais e sociais para arcar com um advogado particular. Entretanto, é interessante observar que a redação do dispositivo foi dada por meio da Emenda Constitucional $\mathrm{n}^{\circ}$ 80, de 2014, pois antes, o texto do constituinte originário dizia apenas que: “A Defensoria Pública é instituição essencial à função jurisdicional do Estado, incumbindo-lhe a orientação jurídica e a defesa, em todos os graus, dos necessitados, na forma do art. $5^{\circ}$, LXXIV.".

Além disso, o parágrafo primeiro do art. 134 da Constituição Federal, renumerado pela Emenda Constitucional $n^{\circ} 45$, de 2004, disciplina que "Lei Complementar organizará a Defensoria Pública da União e do Distrito Federal e dos Territórios, assim como prescreverá normas gerais para sua organização nos Estados." Com isso, a expressão "organizar" passa a ser compreendida de maneira extensa, abrangendo a estrutura, as

\footnotetext{
${ }^{75}$ BRASIL. Constituição (1988). Acesso em: 05 nov. 2017.
} 
atribuições, a carreira, garantias, prerrogativas, deveres, proibições, impedimentos, objetivos, responsabilidade funcional e a normatização de direitos ${ }^{76}$.

A Lei Complementar $n^{\circ} 80$ foi editada em 1994, em obediência ao dispositivo acima citado, e regulamentou a instituição em nível nacional, sendo prevista também a sua forma de organização interna, suas funções, seus princípios institucionais e garantias. O professor Guilherme Peña de Moraes expressa que esta lei se caracteriza como uma lei nacional com conteúdo formado por normas gerais para a organização das Defensorias Públicas Estaduais ${ }^{77}$.

Diogo Esteves e Franklyn Roger Alves Silva mostram isso:

Ao organizar a Defensoria Pública da União, do Distrito Federal e dos Territórios, a Lei Complementar $n^{\circ}$ 80/1994 mostra-se exaustiva, cuidando detalhadamente de sua estrutura, carreira, atribuições, direitos e responsabilidades (Título II - "Da Organização da Defensoria Pública da União" e Título III - "Da Organização da Defensoria Pública do Distrito Federal e Dos Territórios"). Por outro lado, ao dispor sobre as Defensorias Públicas Estaduais, a Lei Complementar $\mathrm{n}^{\circ}$ 80/1994 traça apenas as normas gerais sobre a matéria, deixando a cargo dos Estados-membros a devida especificação dos pormenores (Título IV - "Das Normas Gerais para a Organização da Defensoria Pública dos Estados") $)^{78}$.

Em 2009, a Lei Complementar $n^{\circ} 132$ deu uma nova redação para a Lei anterior, inovando a ordem jurídica da Defensoria Pública por meio de novas regras que aproximam a instituição da sociedade. Uma das suas grandes novidades pauta-se na solução extrajudicial dos litígios por meio da mediação e da conciliação. Além disso, há previsão consagrando a descentralização da instituição por meio da criação de núcleos especializados, ou seja, há a necessidade de que nas regiões "com maiores índices de exclusão e adensamento populacional" tenha-se uma Defensoria Pública atuando de forma efetiva. Leonardo Lorea Mattar acrescenta:

\footnotetext{
${ }^{76}$ ESTEVES, ALVES SILVA, 2017, p. 124.

77 MORAES, Guilherme Peña de. Instituições da Defensoria Pública. São Paulo: Malheiros Editores, 1999. p. 149.

${ }^{78}$ ESTEVES, ALVES SILVA, op. cit., p. 124.
} 
“quando o texto prevê núcleos em regiões mais carentes, é com a função de quebrar a lógica de que o órgão deve seguir a linha de pensamento do Judiciário" 79.

Outro aspecto importante da Lei Complementar $n^{\circ} 132$ encontra amparo no art. 97-A da $\mathrm{LC}^{\circ}$ 132. Este dispositivo preconiza a autonomia funcional da instituição, no sentido de que a Defensoria poderá abrir concurso público quando existirem vagas não preenchidas, por exemplo. Ademais, o art. 89, inciso VII, dispõe que o defensor público tem livre ingresso em estabelecimentos policiais, prisionais e de internação coletiva, demonstrando que todos têm direito a uma ampla defesa.

O parágrafo segundo do art. 134 da Constituição Federal foi incluído por meio da Emenda Constitucional no 45, de 2004, e determina que "às Defensoria Públicas Estaduais são asseguradas autonomia funcional e administrativa e a iniciativa de sua proposta orçamentária”. Vale dizer que essas prerrogativas também são conferidas às Defensorias Públicas do Distrito Federal e da União, por conta da edição das Emendas Constitucionais de $n^{\circ} 69$, de 2012, e de $n^{\circ} 74$, de 2013, que trouxeram essa previsão, respectivamente.

$\mathrm{O}$ art. 134 da Constituição Federal também traz o parágrafo $4^{\circ}$, introduzido no texto constitucional por meio da Emenda Constitucional $n^{\circ}$ 80, de 2014, consagrando como princípios institucionais da instituição, a unidade, a indivisibilidade e a independência funcional. Por força desta mesma Emenda foi editado o art. 98 do ADCT, prevendo um dever constitucional do Estado em ampliar a atuação da Defensoria Pública, aumentando, dessa forma, o serviço público de assistência jurídica.

É preciso citar também a Lei $\mathrm{n}^{\circ} 11.448$, de 2007, que legitima a Defensoria Pública para propor ação civil pública em prol dos direitos difusos, coletivos e individuais homogêneos. Seguindo essa mesma linha, a

\footnotetext{
79 SCHIAVON, Fabiana. Nova Lei da Defensoria dá início a Reestruturação. Disponível em: <https://www.conjur.com.br/2009-out-10/lei-defensoria-primeiro-passo-reestruturacao-orgao>. Acesso em: 30 abr. 2018.
} 
Lei 13.300, de 2016, atribui legitimidade para a instituição propor mandado de injunção coletivo. Dessa forma, fica nítido que esta instituição tem como atribuição a proteção dos direitos fundamentais de todas as dimensões, sejam eles individuais ou coletivos.

Por último, mas não menos importante, a Defensoria Pública encontra respaldo no novo Código de Processo Civil, com a inclusão de título próprio para a instituição, assim como afirma Tiago Fensterseifer:

O seu art. 185 reproduz basicamente o conteúdo do art. $1^{\circ}$ da LC 80/94 e do art. 134, caput, da CF/88, reforçando tanto a atuação da Defensoria Pública na tutela e promoção dos direitos fundamentais (e direitos humanos) quanto a sua possibilidade de atuação no campo dos direitos coletivos (individuais homogêneos, coletivos em sentido estrito e difusos) ${ }^{80}$.

É possível concluir, portanto, termos um vasto conjunto de regras que regulamentam a Defensoria Pública como uma instituição apta a consagrar a dignidade da pessoa humana. Além de ficar clara a importância e a necessidade de conhecer as normas que regem este modelo de assistência jurídica.

\subsection{Características da Defensoria Pública}

No tópico anterior, foi possível analisar e perceber que a Emenda Constitucional $\mathrm{n}^{\mathbf{0}}$ 45, de 2004, responsável pela Reforma do Poder judiciário, conferiu às Defensorias Públicas estaduais, autonomia funcional e administrativa, bem como iniciativa para as propostas orçamentárias dentro dos limites estabelecidos na lei de diretrizes orçamentárias e de acordo com o disposto no art. 99, $\S 2^{\circ}$, da Constituição Federal.

Entretanto, não havia previsão expressa a respeito das Defensorias Públicas da União e do Distrito Federal, gerando discussões sobre a constitucionalidade do dispositivo, já que havia claramente um vício de omissão no texto constitucional. Por conta disso, a Associação Nacional dos

\footnotetext{
${ }^{80}$ FENSTERSEIFER, 2017, p. 11-12.
} 
Defensores Públicos da União propôs a ADI n 4.282/DF, requerendo que o art. $134, \S 2^{\circ}$, da Constituição (com a redação dada pela Emenda $n^{\circ} 45$ ) fosse ampliado para seguir os ditames da técnica de interpretação conforme a Constituição.

Vale dizer que, mais tarde, o poder constituinte derivado reformador foi o encarregado de editar as Emendas Constitucionais de $\mathrm{n}^{\circ} 69$ e de $\mathrm{n}^{\mathrm{o}} 74$. A primeira delas ampliou a incidência do art. $134, \S 2^{\circ}$, da Constituição somente para as Defensorias Públicas do Distrito Federal, enquanto que a segunda incluiu o $\$ 3^{\circ}$ no art. 134 da Constituição Federal, possibilitando a aplicação da autonomia funcional, administrativa e financeira para as Defensorias Públicas do Distrito Federal e da União, alcançando-se, assim, uma similitude entre todas elas.

Há um motivo especial para conferir autonomia institucional às Defensorias Públicas. Essa atribuição ocorre para garantir a liberdade de atuação da Instituição em prol do acesso à justiça. Tiago Fensterseifer explica que o real motivo estaria calcado na preocupação com a proteção dos mais vulneráveis na sociedade:

\begin{abstract}
No caso da Defensoria Pública, a autonomia institucional está a serviço justamente dos indivíduos e grupos sociais necessitados, já que os direitos e interesses destes contrapõem-se, muitas vezes, aos interesses do próprio Estado (nos âmbitos federal, estadual e municipal), como se verifica, por exemplo, na reivindicação de direitos sociais em face do Poder Executivo. É por tal razão e com essa preocupação em mente, ou seja, a proteção dos vulneráveis, que o constituinte derivado entendeu por bem reforçar o regime jurídico da Defensoria Pública com as autonomias que lhe foram atribuídas ${ }^{81}$.
\end{abstract}

José Afonso da Silva explica que a autonomia funcional conferida a uma instituição, nada mais é que "o exercício de suas funções livre de ingerência". Esta característica permite que a Defensoria Pública lute pelos direitos dos socialmente reprimidos e até mesmo contra o Poder Público, além de proporcionar liberdade para que a Instituição atue e cumpra as suas

\footnotetext{
${ }^{81}$ FENSTERSEIFER, 2017, p. 129.
} 
funções institucionais seguindo os limites impostos pelos ditames constitucionais e legais.

Daniel Sarmento destaca que:

Após a aprovação das EC no 45/2004 e $n^{\circ} 74 / 2013$, as Defensorias Públicas passaram a desfrutar de total independência em relação aos demais poderes do Estado. Com tais emendas, objetivou-se robustecer a Defensoria Pública, assegurando-lhe verdadeira blindagem institucional perante os demais poderes, contra os quais ela tem, frequentemente, que pelejar em prol das camadas socialmente vulneráveis da população. Essa autonomia, diga-se de passagem, é essencial para o efetivo cumprimento da sua missão constitucional ${ }^{82}$.

Falar da autonomia administrativa também é importante e significa, nos moldes de José Afonso da Silva:

Que cabe à Instituição organizar sua administração, suas unidades administrativas, praticar atos de gestão, decidir sobre situação funcional de seu pessoal, propor ao Poder Legislativo a criação e extinção de seus serviços auxiliares, prover cargos nos termos da lei, estabelecer a política remuneratória, observado o art. 169, e os planos de carreira de seu pessoal, tal como está previsto para o Ministério Público ${ }^{83}$.

Nesse mesmo sentido, Diogo Esteves e Franklyn Roger Alves Silva afirmam que por força da autonomia administrativa, resta vedada a vinculação da Defensoria Pública a qualquer outra estrutura do Estado, reafirmando-se sua posição como instituição "extra poder”. O STF também adotou posição similar ao declarar inconstitucional a vinculação da Instituição à estrutura do Poder Executivo, reconhecendo a aplicação imediata e de eficácia plena do art. $134, \S 2^{\circ}$, da Constituição Federal ${ }^{84}$.

Um exemplo dessa autonomia, analisado pelos autores citados, permite à Defensoria estabelecer a distribuição territorial dos membros da carreira, de maneira independente e livre da interferência dos demais Poderes Estatais. Entretanto, vale dizer que essa atividade administrativa

82 SARMENTO, Daniel. Parecer sobre as dimensões constitucionais da Defensoria Pública da União. Disponível em: 〈http://www.anadef.org.br/images/Parecer_ANADEF_CERTO.pdf $>$. Acesso em: 03 mai. 2018.

${ }^{83}$ SILVA, José Afonso da. Comentário contextual à Constituição. $6^{\mathrm{a}}$ ed., São Paulo: Malheiros, 2009. p. 616.

${ }^{84}$ ESTEVES, ALVES SILVA, 2017, p. 88. 
não está imune ao controle jurisdicional, caso seja verificada alguma ilegalidade ou inconstitucionalidade nos critérios adotados pela Defensoria Pública ${ }^{85}$.

Em relação à autonomia financeira, Hely Lopes Meirelles diz que é “a capacidade de elaboração da proposta orçamentária e de gestão e aplicação dos recursos destinados a prover as atividades e serviços do órgão titular da dotação"\$86. A Lei Complementar n 132 acrescentou à Lei Complementar $\mathrm{n}^{\circ} 80$ o artigo 97-B, realizando a regulamentação da proposta orçamentária para a Defensoria Pública dos Estados e analogicamente para a Defensoria Pública da União e do Distrito Federal.

Além disso, o legislador constituinte reconheceu à Defensoria Pública poder de iniciativa legislativa, conhecida por muitos como autonomia legislativa. Entretanto, os autores Diogo Esteves e Franklyn Roger preferem utilizar a terminologia "iniciativa legislativa":

Embora muitos doutrinadores utilizem a denominação "autonomia legislativa", revela-se mais adequada a utilização da expressão "iniciativa legislativa". Dizer que a Defensoria Pública detém autonomia legislativa implica uma confusão terminológica entre o poder regulamentar interno da instituição (edição de Resoluções, Deliberações, Portarias, Atos Conjuntos etc.), que decorre da autonomia administrativa, e a edição de Leis Complementares sobre o regime jurídico da instituição e Leis Ordinárias sobre temas correlatos à Defensoria Pública, a verdadeira iniciativa legislativa ${ }^{87}$.

Dito isto, "em se tratando da tutela e promoção de direitos fundamentais, tanto em sede individual quanto coletiva, a autonomia institucional é peça chave para o bom desempenho das suas atribuições"

\footnotetext{
${ }^{85}$ ESTEVES, ALVES SILVA, 2017, p. 93.

${ }^{86}$ MEIRELLES, Hely Lopes. Direito Administrativo Brasileiro. São Paulo: Malheiros, 2013 apud ESTEVES, Diogo; ALVES SILVA, Franklyn Roger. Princípios Institucionais da Defensoria Pública. $2^{\mathrm{a}}$ ed. Rio de Janeiro: Forense, 2017. p. 94.

${ }^{87}$ ESTEVES, ALVES SILVA, op. cit., p. 103.

${ }^{88}$ FENSTERSEIFER, 2017, p. 136.
} 


\title{
2.4 Natureza Jurídica da Defensoria Pública
}

É imprescindível estabelecer que a doutrina clássica determina que a instituição tem natureza jurídica de órgão público, "pois constitui-se em um centro de competências instituído para o desempenho de funções estatais específicas, por meio de agentes que têm sua atuação imputada à pessoa jurídica a que pertencem" ${ }^{89}$. Sendo um órgão público, a Defensoria Pública estaria vinculada ao Poder Executivo.

Guilherme Peña de Moraes explicita:

\begin{abstract}
A Defensoria Pública, sob o espectro da organização da Administração Pública, consiste em órgão, embora funcionalmente independente, vinculado ao Poder Executivo. (...) Entrementes, acerca da classificação dos órgãos públicos, a Defensoria Pública, com pertinência aos distintos critérios, é qualificada como órgão central, independente, de autoridade, composto, colegiado e obrigatório ${ }^{90}$.
\end{abstract}

Sérgio Luiz Junkes também segue a mesma linha:

A Defensoria Pública é um órgão. Ou seja, constitui um centro de atribuições específicas instituído para o desempenho de funções estatais, por intermédio de seus agentes, cuja atuação é imputada à pessoa jurídica a que pertence. Tocante à esfera de ação, a Defensoria Pública é um órgão central, pois a sua atribuição de prestar assistência jurídica integral é exercida em todo o território da base política em cuja estrutura administrativa é contida. Em relação à posição estatal, em conformidade com o escalonamento administrativo, a Defensoria Pública é um órgão do tipo independente, tendo em vista a independência funcional ${ }^{11}$.

Entretanto, é necessário salientar que a doutrina mais moderna defende que a Defensoria Pública não é um órgão público. Esse novo entendimento surgiu por conta da autonomia funcional, administrativa e financeira atribuídas à Instituição, como foi visto no tópico acima. Diogo Esteves e Franklyn Roger Alves da Silva explicam:

\footnotetext{
${ }^{89}$ SOUZA, Carlos Eduardo Freitas de.; SILVA, Bruna Gomes da. Defensoria Pública na Tutela Jurídica do Meio Ambiente. Disponível em: <https://www.anadep.org.br/wtksite/cms/conteudo/20667/CARLOS_EDUARDO_FREITAS_DE_ SOUZA_E_BRUNA_GOMES_DA_SILVA.pdf $>$. Acesso em: 30 abr. 2018.

${ }^{90}$ MORAES, 1999, p. 160-161.

${ }^{91}$ JUNKES, Sérgio Luiz. Defensoria Pública e o Princípio da Justiça Social. Curitiba: Juruá, 2006. p. 83-84 apud ESTEVES, Diogo; ALVES SILVA, Franklyn Roger. Princípios Institucionais da Defensoria Pública. $2^{\mathrm{a}}$ ed. Rio de Janeiro: Forense, 2017. p. 311.
} 
Ao prever a Defensoria Pública em capítulo autônomo, houve a renúncia por parte do constituinte em definir explicitamente a instituição entre os Poderes do Estado, outorgando-lhe a necessária autonomia para o exercício de suas atribuições constitucionais ${ }^{92}$.

Dessa forma, pode-se dizer que não há motivos para que a Defensoria Pública continue sendo subordinada ao Poder Executivo. É o que os autores justificam ao explicar a relação existente entre um órgão e uma pessoa jurídica:

Como unidades abstratas que condensam os vários círculos de atribuições estatais, os órgãos públicos constituem simples repartições internas da pessoa jurídica a que pertencem. Com isso, subsiste estreita relação vinculativa entre o órgão público e a entidade em cuja intimidade estrutural se encontra inserido. Justamente por serem caracterizados como frações corpusculares da pessoa jurídica a que estão atrelados, os órgãos públicos não possuem personalidade autônoma ou vontade própria, que são atributos do corpo, e não das partes ${ }^{93}$.

Com isso, "por não estar acessoriamente vinculada a nenhum corpo principal e por não constituir simples plexo de atribuições da administração estatal, não pode a Defensoria Pública ser tecnicamente classificada como órgão público" ${ }_{94}$. Pois, a Instituição não está atrelada a nenhuma pessoa jurídica de direito público, tendo total autonomia para realizar suas funções, assim como seus membros.

Diogo Esteves e Franklyn Roger Alves da Silva, seguindo a doutrina moderna, concluem pela natureza jurídica da Defensoria Pública de uma "Instituição Constitucional” ou uma "Instituição Primária do Estado Democrático de Direito contemporâneo":

Na realidade, em virtude de sua peculiar posição constitucional, a Defensoria Pública não deve ser enquadrada em nenhuma categoria jurídica preexistente no universo do Direito, integrando grupo autônomo e singular, juntamente com o Ministério Público. (...) Desse modo, como estrutura originária diretamente da Constituição Federal e representativa da função de provedoria de justiça, a

\footnotetext{
${ }^{92}$ ESTEVES, ALVES SILVA, 2017, p. 311.

${ }^{93}$ Ibid., p. 312.

${ }^{94}$ Ibid., p. 312.
} 
Defensoria Pública possui natureza jurídica de Instituição Constitucional ou Instituição Primária do Estado Democrático de Direito contemporâneo ${ }^{95}$.

Tiago Fensterseifer segue a mesma linha de raciocínio ao dizer que:

Tanto o Ministério Público (caput do art. 127) quanto a Defensoria Pública (caput do art. 134) são reconhecidos pelo texto constitucional como "instituições permanentes" da configuração do Estado brasileiro. A atribuição da nomenclatura "instituição" revela que ambas as instituições não são "órgão", expressão utilizada no âmbito do regime administrativista como ente geralmente subordinado e integrante de algum dos Poderes Republicanos. O mesmo não ocorre com a expressão "instituição", dotada de outro regime jurídico compatível com a ideia de autonomia e independência em relação a outros poderes estatais ${ }^{96}$.

\subsection{Objetivos da Defensoria Pública}

A instituição possui o seu foco de atuação na população carente em termos socioeconômicos, principalmente, encarregando-se da transformação de sua realidade no sentido de assegurar condições mínimas de bem-estar ${ }^{97}$. A respeito dos objetivos da Defensoria Pública, é necessário reproduzir aqui o art. $3^{\circ}$ - A da Lei Complementar 80/94, incluído pela Lei Complementar 132 em 2009:

Art. 3--A. São objetivos da Defensoria Pública: I - a primazia da dignidade da pessoa humana e a redução das desigualdades sociais; II - a afirmação do Estado Democrático de Direito; III - a prevalência e efetividade dos direitos humanos; e IV - a garantia dos princípios constitucionais da ampla defesa e do contraditório $^{98}$.

A partir deste artigo, pode-se perceber que:

A Defensoria Pública tem uma razão bastante significativa para existir, especialmente se os setores políticos estiverem efetivamente comprometidos com o projeto normativo delineado pela $\mathrm{CF} / 88$. (...) Bem-estar, justiça social e vida digna estão no âmago do nosso texto constitucional conferindo fundamento e

\footnotetext{
${ }^{95}$ ESTEVES, ALVES SILVA, 2017, p. 312-313.

${ }^{96}$ FENSTERSEIFER, 2017, p. 127.

${ }^{97}$ Ibid., p. 3.

98 BRASIL. Lei Complementar $\mathrm{n}^{\mathrm{o}} 80$ de 12 de Janeiro de 1994. Disponível em: <http://www.planalto.gov.br/ccivil_03/leis/lcp/lcp80.htm?TSPD_101_R0=adc66cbca779b829287 4b84f566a0764z1F000000000000000020058eb1ffff00000000000000000000000000005aeb9b520 06dfae12d>. Acesso em: 01 mai. 2018.
} 
legitimidade para a existência de uma instituição pública com o perfil da Defensoria Pública ${ }^{99}$.

O primeiro objetivo norteador da instituição é a dignidade da pessoa humana, que é um dos fundamentos da República Federativa do Brasil, assim como disciplina o art. $1^{\circ}$, inciso III, da Constituição Federal. Tiago Fensterseifer explica:

Há uma preocupação contemporânea de saber quem de fato é aquela pessoa a que se destina a norma jurídica. Há um novo compromisso do Estado e da sociedade posto na $\mathrm{CF} / 88$ no sentido de que a afirmação de direitos se volta à proteção concreta da pessoa, tomando em conta as suas circunstâncias fáticas reais e eventuais óbices existentes no exercício dos seus direitos ${ }^{100}$.

Ingo Sarlet ensina o que é a dignidade da pessoa humana:

É a qualidade intrínseca e distintiva reconhecida em cada ser humano que o faz merecedor do mesmo respeito e consideração por parte do Estado e da comunidade, implicando, neste sentido, um complexo de direitos e deveres fundamentais que assegurem a pessoa tanto contra todo e qualquer ato de cunho degradante e desumano, como venham a lhe garantir as condições existenciais mínimas para uma vida saudável, além de propiciar e promover sua participação ativa e corresponsável nos destinos da própria existência e da vida em comunhão com os demais seres humanos, mediante o devido respeito aos demais seres que integram a rede da vida ${ }^{101}$.

\section{Diogo Esteves e Franklyn Roger Alves da Silva também expressam} que a dignidade da pessoa humana está na origem dos direitos materialmente fundamentais e representa o núcleo essencial de cada um deles ${ }^{102}$. Ingo Sarlet assevera que este fundamento estará tutelado apenas "quando for possível uma existência que permita a plena fruição dos direitos fundamentais, de modo especial, quando seja possível o pleno desenvolvimento da personalidade" ${ }^{103}$.

Todos os direitos fundamentais, de diferentes dimensões, complementam-se na busca de uma tutela integral e efetiva da dignidade da pessoa humana, não

\footnotetext{
${ }^{99}$ FENSTERSEIFER, 2017, p. 4-5.

100 Ibid., p. 25.

${ }^{101}$ SARLET, 2005, p. 67.

102 ESTEVES, ALVES SILVA, 2017, p. 352.

${ }^{103}$ SARLET, op. cit., p. 311.
} 
havendo, portanto, como defendem alguns, primazia ou superioridade hierárquica entre tais direitos como decorrência de integrarem uma geração precedente ${ }^{104}$.

Maria Celina Bodin de Moraes desdobra a dignidade da pessoa humana em aspectos bem específicos:

I) o sujeito moral (ético) reconhece a existência dos outros como sujeitos iguais a ele; ii) merecedores do mesmo respeito à integridade psicofísica de que é titular; iii) é dotado de vontade livre, de autodeterminação; iv) é parte do grupo social, em relação ao qual tem a garantia de não vir a ser marginalizado ${ }^{105}$.

Portanto, existem quatro vertentes principiológicas: a da igualdade, liberdade, integridade psicofísica e da solidariedade. Todos esses princípios, de âmbito constitucional, se respeitados, consagram os próprios direitos fundamentais. Dessa forma, fica nítido perceber que a Defensoria Pública "pode (e deve) atuar na defesa de todos os direitos fundamentais, de todas as diferentes dimensões (liberal, social e ecológica)"106 desenvolvendo a sua atuação com o intuito de promover todos esses valores em prol do mínimo existencial.

O segundo objetivo pauta-se na redução das desigualdades sociais, que é um dos objetivos fundamentais da República Federativa do Brasil, expresso no art. $3^{\circ}$, inciso III, da Constituição Federal.

O anseio pela superação das profundas desigualdades sociais e econômicas, que muitas vezes torna vazia de sentido uma das premissas fundamentais do Estado de Direito - que é igualdade de todos perante a Lei e a Justiça! -, levou o Poder Constituinte originário que produziu a Constituição da República Federativa do Brasil de 1988 a estabelecer, entre várias medidas, a Defensoria Pública como instituição essencial à atividade jurisdicional do Estado ${ }^{107}$.

Por meio da atuação da Defensoria Pública, as pessoas desprovidas de recursos financeiros, por exemplo, podem ter acesso à justiça, assim

\footnotetext{
${ }^{104}$ FENSTERSEIFER, 2017, p. 87.

105 MORAES, Maria Celina Bodin de. A Constitucionalização do direito civil e seus efeitos sobre a responsabilidade civil. Disponível em:

<http://egov.ufsc.br/portal/sites/default/files/a_constitucionalizacao_do_direito_civil_e_seus.pdf >.

Acesso em: 01 abr. 2018.

${ }^{106}$ FENSTERSEIFER, op. cit., p. 88.

${ }^{107}$ Ibid., Apresentação feita por Cleber Francisco Alves.
} 
como aquelas que conseguem contratar um advogado particular. Com isso, a instituição viabiliza a igualdade entre os desiguais economicamente, socialmente e culturalmente, possibilitando uma assistência jurídica para os menos favorecidos na sociedade brasileira e igualando-os com a minoria beneficiada.

Vale mencionar o princípio da igualdade para explicar que, por vezes é preciso tratar os desiguais de forma dissemelhante para justamente aproximá-los. Tiago Fenterseifer mostra que este princípio faz com que determinados indivíduos ou grupos sociais sejam tratados de forma desigual a fim de afirmar-se a sua igualdade material. É por conta disso que a Defensoria Pública direciona a sua atuação somente para os menos beneficiados economicamente, os chamados hipossuficientes.

É possível pensar aqui, a título de exemplo, na paridade de armas durante o curso de um processo judicial. O novo Código de Processo Civil, em seu artigo $7^{\circ}$, dispõe a respeito da igualdade no tratamento em relação ao exercício de direitos e faculdades processuais, explicitando que o poder público deve garantir proporção e tratamento igualitário às partes envolvidas. Por isto, Cleber Francisco Alves diz que:

Torna-se imprescindível dotar a Defensoria Pública de condições materiais e humanas e de instrumentos adequados para que possa cumprir sua missão constitucional de viabilizar o acesso à justiça àqueles desprovidos de recursos econômicos, que são efetivamente a maioria os que integram a sociedade brasileira $^{108}$.

O terceiro objetivo encontra respaldo na afirmação do Estado Democrático de Direito. A Defensoria Pública é uma das responsáveis pela consagração deste Estado que visa salvaguardar a cidadania, o acesso à justiça e a efetivação dos direitos fundamentais, sem privilegiar um grupo específico da população, ou seja, amparando também os mais desfavorecidos.

${ }^{108}$ ALVES, 2006, p. 26. 
Vale dizer que:

A consolidação do Estado Democrático de Direito, depende inexoravelmente do equacionamento desses graves problemas enfrentados pela grande maioria da população brasileira, relacionados ao (in) acesso à Justiça. A superação desse quadro depende, em grande medida, da mobilização da sociedade civil nacional, no sentido de um maior engajamento na conquista de uma cidadania plena, que somente será alcançada com a total efetivação dos direitos fundamentais ${ }^{109}$.

Portanto, fica fácil trabalhar com a ideia de que se o Estado não cumpre a função de proporcionar um verdadeiro e efetivo acesso à justiça para todos, de forma igualitária, as pessoas ficarão desprotegidas, no sentido de não conseguirem alcançar o cumprimento e a realização dos direitos fundamentais consagrados no ordenamento jurídico.

Dessa forma, a Defensoria Pública "possui a irrenunciável incumbência de garantir a perpetuidade da democracia e a continuidade da ordem jurídica"110. Ela foi criada e pensada como uma solução capaz de promover e oportunizar este acesso aos mais necessitados, possibilitando uma forma de perseguir o implemento destes direitos e, automaticamente, dando significado ao Estado Democrático de Direito.

Cleber Francisco Alves observa que:

Um verdadeiro Estado de Direito não pode existir se não houver mecanismos capazes de assegurar que a lei prevalecerá sempre sobre o arbítrio e sobre a força, independentemente das condições de fortuna ou de origem sócia, racial, religiosa, enfim, de quaisquer outros fatores de diferenciação entre os cidadãos ${ }^{111}$.

O quarto objetivo é a prevalência e efetividade dos direitos humanos. $\mathrm{O}$ art. $4^{\circ}$, inciso II, da Constituição Federal disciplina que a República Federativa do Brasil se rege nas suas relações internacionais pela prevalência destes direitos.

A Organização das Nações Unidas estipula que os direitos humanos são comumente compreendidos como aqueles direitos inerentes ao ser

\footnotetext{
${ }^{109}$ ALVES, 2006, p. 28.

${ }^{110}$ ESTEVES, ALVES SILVA, 2017, p. 355.

${ }^{111}$ ALVES, op. cit., p. 158.
} 
humano. Isso significa dizer que cada pessoa pode desfrutar de seus direitos sem distinção de raça, cor, sexo, língua, religião, opinião política ou de outro tipo, origem social ou nacional ou condição de nascimento ou riqueza. Além disso, é importante constar que os direitos humanos são fundados sobre o respeito pela dignidade e o valor de cada pessoa ${ }^{112}$.

A Declaração Universal dos Direitos Humanos, em seu art. 1º, consagra que "todos os seres humanos nascem livres e iguais em dignidade e em direitos". E o art. $3^{\circ}$ dispõe que "todo o indivíduo tem direito à vida, à liberdade e à segurança pessoal" 113 .

A Defensoria Pública, como instituição, existe, então, para promover a efetividade desses direitos no plano nacional e também no plano internacional.

O cenário normativo delineado pelo Direito Internacional dos Direitos Humanos, tanto no âmbito global quanto regional, foi determinante para a própria consagração do direito à assistência jurídica como direito fundamental e mesmo a criação de instituição pública - Defensoria Pública - com tal finalidade na $\mathrm{CF} / 88^{114}$.

Vale dizer que a Defensoria tem o condão de postular perante os órgãos dos sistemas internacionais de proteção aos direitos humanos, pois a ela é conferida esta função no art. $4^{\circ}$, inciso VI, da Lei Complementar $n^{\circ} 80$. Bem como promover a difusão e a conscientização destes direitos (art. $4^{\circ}$, inciso III, da $\mathrm{LC}^{\circ} 80$ ).

Pode-se afirmar que:

Por restar constitucionalmente incumbida de prestar a assistência jurídica aos necessitados, a Defensoria Pública conserva permanente contato com a população carente e marginalizada, possuindo melhores condições de identificar eventuais

112 Site Oficial da Organização das Nações Unidas. Disponível em: <https://nacoesunidas.org/direitoshumanos/>. Acesso em: 02 mai. 2018.

113 Declaração Universal dos Direitos Humanos. Disponível em: <http://www.ohchr.org/EN/UDHR/Documents/UDHR_Translations/por.pdf>. Acesso em: 02 mai. 2018.

${ }^{114}$ FENSTERSEIFER, 2017, p. 165-166. 
violações aos direitos humanos - que, via de regra, ocorrem justamente em face dos desprovidos de fortuna ${ }^{115}$.

O quinto objetivo expresso na Lei Complementar da Defensoria Pública é a garantia dos princípios constitucionais da ampla defesa e do contraditório. $\mathrm{O}$ art. $5^{\circ}$, inciso $\mathrm{LV}$, da Constituição Federal expressa de forma clara que aos litigantes, em processo judicial ou administrativo, e aos acusados em geral são assegurados o contraditório e ampla defesa ${ }^{116}$.

Gilmar Ferreira Mendes explica que o contraditório e a ampla defesa não têm aplicação apenas nas manifestações das partes nos processos judiciais e administrativos, isto é, são princípios que devem ser obedecidos para atingir a finalidade máxima do processo, que é a pretensão perquirida. E a Defensoria Pública possui um papel primordial para garantir que esses preceitos constitucionais sejam cumpridos:

\begin{abstract}
Nesse ponto, a atuação jurídico-assistencial da Defensoria Pública funciona como elemento equilibrador do status social no processo, garantindo aos deserdados de fortuna a mesma oportunidade de influir na formação da decisão judicial. Por essa razão, ao cumprir o objetivo preconizado pelo art. $3^{\circ}-\mathrm{A}$, IV, da LC ${ }^{\circ} 80 / 1994$, a Defensoria Pública preserva e garante a realização processual do princípio da isonomia, dentro da essência filosófica da democracia ${ }^{117}$.
\end{abstract}

A partir da elucidação de todos os objetivos da Instituição, percebese que a sua atuação gera um grande impacto na sociedade brasileira de forma a privilegiar o acesso à justiça. Dirley da Cunha Júnior assevera que as Defensorias Públicas são uma das mais importantes e fundamentais ferramentas de afirmação judicial dos direitos humanos e do fortalecimento do Estado Democrático de Direito, isso porque atuam de forma a beneficiar a parte mais carente da sociedade ${ }^{118}$.

\footnotetext{
${ }^{115}$ ESTEVES, ALVES SILVA, 2017, p. 357.

${ }^{116}$ MENDES, Gilmar Ferreira et al. Curso de Direito Constitucional. $4^{\mathrm{a}}$ ed. São Paulo: Saraiva, 2009. p. 592.

${ }^{117}$ ESTEVES, ALVES SILVA, op. cit., p. 358.

${ }^{118}$ CUNHA JÚNIOR, Dirley da. Curso de Direito Constitucional. Salvador: JusPodivm, 2008. p. 979.
} 


\subsection{Princípios Institucionais da Defensoria Pública}

Os princípios têm uma existência muito significativa no exercício e na atuação da Defensoria Pública, pois são grandes impulsionadores e auxiliam na realização das funções e na interpretação e aplicação das regras, de forma a garantir uma defesa efetiva dos direitos fundamentais aos necessitados.

$\mathrm{O}$ art. $134, \S^{\circ}$, da Constituição Federal traz de forma expressa e exemplificativa os princípios norteadores da Instituição, são eles: princípio da unidade, princípio da indivisibilidade e princípio da independência funcional. Cabe ressaltar que o art. $3^{\circ}$ da Lei Complementar $n^{\circ}$ 80, de 94, também traz em seu texto a mesma previsão, consagrando e reforçando a aplicação principiológica na ordem jurídica de atuação da Defensoria Pública.

Diogo Esteves e Franklyn Roger classificam os princípios da Defensoria Pública como princípios materiais setoriais, pois presidem um conjunto específico de normas afetas à Instituição ${ }^{119}$.

O primeiro princípio é o da unidade. Guilherme Peña de Moraes explica que pela unidade ou unicidade compreende-se que a Defensoria Pública constitui um todo orgânico submetido a idênticos fundamentos, direção e finalidade ${ }^{120}$. José Afonso da Silva ${ }^{121}$ ressalta que esta unidade só é encontrada no âmbito de cada Defensoria Pública, isto é, na da União, do Distrito Federal e dos Estados. Isso ocorre porque cada uma é composta por uma estrutura organizacional distinta. Dessa forma, do ponto de vista orgânico, não há qualquer vinculação hierárquica, administrativa ou financeira entre as Defensorias Públicas da União, dos Estados, do Distrito

\footnotetext{
${ }^{119}$ ESTEVES; ALVES SILVA, 2017, p. 327.

${ }^{120}$ MORAES, 1999, p. 173.

121 SILVA, José Afonso da. Comentário Contextual à Constituição. 9a ed. São Paulo: Malheiros, 2014. p. 628.
} 
Federal e dos Territórios, possuindo cada uma delas organização autônoma e distinta ${ }^{122}$.

Por outro lado, do ponto de vista funcional, há unidade entre todas as Defensorias Públicas, pois todas desempenham a mesma finalidade e idêntica função, a de cumprir com todos os objetivos institucionais ${ }^{123}$. Além desses dois aspectos da unidade, existe ainda um terceiro, o da singularidade normativa, ou seja, as normas gerais precisam ser comuns para todas as Defensorias Públicas - a da União, do Distrito Federal e dos Estados.

Segundo entendimento de Caio Paiva, o princípio da unidade possui então um caráter tríplice, visto que, é dividido em unidade hierárquicoadministrativa, pautada na estrutura organizacional; unidade funcional, a que permite o desempenho das funções institucionais; e unidade normativa, responsável por orientar a legislação institucional e assegurar a unicidade legislativa ${ }^{124}$.

O segundo princípio é o da indivisibilidade, que garante que a atuação da Defensoria Pública ocorra de maneira contínua ${ }^{125}$. Esta norma principiológica guarda conexão com o princípio da unidade, isso porque a Instituição não pode ser fragmentada, como defende Tiago Fensterseifer:

Os princípios da unidade e da indivisibilidade estão entrelaçados e repercutem justamente na conformação da Defensoria Pública como instituição una e indivisível, o que reflete no fortalecimento e blindagem da sua atuação no plano federativo. Se o princípio da unidade busca assegurar uniformidade de regime jurídico entre os diferentes planos federativos (Defensoria Pública d União, Defensoria Pública do Distrito Federal e Defensoria Pública dos Estados), conformando a ideia de que se trata de uma mesma instituição de expressão nacional no âmbito do Sistema de Justiça (muito embora tal unidade exista, em termos práticos, apenas dentro de cada instituição), o princípio da indivisibilidade opera como uma derivação do primeiro, ou seja, impedindo que as atribuições institucionais se deem de forma fragmentada pelo prisma da atuação dos Defensores Públicos e assegurando (também por força do princípio da

${ }^{122}$ ESTEVES, ALVES SILVA, 2017, p. 328.

${ }^{123}$ Ibid., p. 328.

124 PAIVA, Caio. Prática Penal para a Defensoria Pública. Rio de Janeiro: Forense, 2016. p. 3033 apud ESTEVES, Diogo; ALVES SILVA, Franklyn Roger. Princípios Institucionais da Defensoria Pública. $2^{\mathrm{a}}$ ed. Rio de Janeiro: Forense, 2017. p. 329.

${ }^{125}$ ESTEVES, ALVES SILVA, op. cit., p. 330. 
impessoalidade) a continuidade do serviço público (ante situações, por exemplo, de substituição e afastamento de Defensores Públicos). É como se o primeiro dos princípios estivesse voltado ao plano externo e o segundo ao plano interno institucional ${ }^{126}$.

Diogo Esteves e Franklyn Roger salientam que através dessa indivisibilidade é possível que os membros que compõem a Instituição sejam substituídos sem que haja o fracionamento da mesma.

Por conta da indivisibilidade, os membros da Defensoria Pública não se vinculam aos processos em que atuam, sendo relativamente comum que um mesmo processo seja conduzido sucessivamente por Defensores Públicos distintos. Desde que observada a sistemática legal, um Defensor poderá substituir outro que se encontre afastado por ocasião de férias, licença, impedimento, suspeição, etc. ${ }^{127}$.

Esses mesmos autores mostram que a indivisibilidade, por vezes, é necessária para que as atividades da Defensoria Pública sejam contínuas. Além disso, essa substituição não implica em vinculação de opiniões, isto é, o Defensor Público não é obrigado a adotar os mesmos pensamentos daquele que foi substituído. Isso ocorre em virtude do princípio da independência funcional, o terceiro deles.

O último princípio aqui exposto, segundo Sílvio Roberto Mello Moraes ${ }^{128}$, permite ao Defensor Público atuar com inteira liberdade, agindo de acordo com a sua própria consciência, devendo seguir apenas os ditames constitucionais e legais. Diogo Esteves e Franklyn Roger explicam:

Além de estarem livres de interferências externas, os Defensores Públicos funcionalmente não se encontram submetidos a qualquer poder hierárquico interno, não estando vinculados às recomendações exaradas pelo escalão superior da Defensoria Pública. Por essa razão, não pode o Defensor ser penalizado pelos atos probos praticados no estrito exercício de suas funções, mesmo que tal conduta contrarie orientação expedida pela chefia institucional da Defensoria Pública. Na verdade, por conta do princípio da independência funcional, a

\footnotetext{
${ }^{126}$ FENSTERSEIFER, 2017, p. 137.

${ }^{127}$ ESTEVES, ALVES SILVA, 2017, p. 330.

128 MORAES, Sílvio Roberto Mello. Princípios Institucionais da Defensoria Pública: Lei Complementar no 80 de 12.1.1994. São Paulo: Revista dos Tribunais, 1995. p. 94.
} 
hierarquia interna existente na Instituição deve restringir-se às questões de ordem administrativa, nunca de caráter funcional ou técnico ${ }^{129}$.

Vale destacar o art $4^{\circ}, \S 2^{\circ}$, da Lei Complementar $n^{\circ} 80$, de 1994, dispondo que as funções institucionais da Defensoria Pública serão exercidas inclusive contra as Pessoas Jurídicas de Direito Público. Isso demonstra mais uma incidência do princípio da independência funcional no plano de atuação da Instituição.

Um dos questionamentos existentes guarda relação com os limites impostos para a atuação dos Defensores Públicos. Dessa forma, Diogo Esteves e Franklyn Roger asseveram que assim como todo e qualquer agente político, eles devem estar obrigatoriamente baseados em autorização conferida por norma válida e pautados na finalidade institucional de promover os direitos fundamentais aos hipossuficientes, assim como garantir um efetivo acesso à justiça.

Outra discussão é sobre a diferenciação entre o princípio da independência funcional e a autonomia funcional. Primeiramente, essas expressões não são sinônimas, mas guardam a mesma finalidade, ou seja, a liberdade de agir. A primeira delas é destinada ao titular do cargo, garantindo-lhe liberdade de consciência e atuação, enquanto a segunda é designada à Instituição, determinando que esta não seja subordinada a nenhum dos Poderes Estatais.

Depois da exposição dos princípios que norteiam a existência da Defensoria Pública, é preciso tratar da temática que aborda as funções institucionais da mesma. Tudo isso para tornar viável a conexão de todas essas prerrogativas da Instituição com o direito fundamental do acesso à justiça, direito este capaz de propiciar todos os demais.

\footnotetext{
${ }^{129}$ ESTEVES, ALVES SILVA, 2017, p. 331.
} 


\subsection{Funções Institucionais da Defensoria Pública}

A Defensoria Pública tem como um de seus objetivos primordiais a promoção da dignidade da pessoa humana e a tutela dos direitos fundamentais. É através da Instituição que as pessoas hipossuficientes têm a oportunidade de perseguir os seus direitos, seja no âmbito judicial ou no extrajudicial. Por conta disso, a Defensoria conta com um rol de funções específicas que tendem a impulsionar o acesso à justiça de forma efetiva.

Os Professores Humberto Peña de Moraes e José Fontenelle Teixeira da Silva ${ }^{130}$ dividiram essas funções em típicas e atípicas para demonstrar que nem sempre as necessidades das pessoas estão vinculadas apenas às condições econômicas, como foi explicitado no primeiro capítulo da monografia, seguindo o entendimento de Boaventura de Sousa Santos. Com isso, pode-se afirmar que os problemas vão além, estão ligados a fatores sociais, culturais, organizacionais, processuais, etc. Por conta disso, o termo "necessitados" no art. 134 da Constituição Federal deve ser entendido de forma ampla, ou seja, deve ser feita uma interpretação teleológica dessa expressão. Diogo Esteves e Franklyn Roger afirmam que:

Seguindo a destinação fundamental da Defensoria Pública, delineada pelo mínimo constitucional contido no art.134 c/c art. 5 , LXXIV da CRFB, são consideradas funções típicas aquelas exercidas com o objetivo de tutelar direitos titularizado por hipossuficientes econômicos. Sempre que a atividade funcional da Defensoria Pública restar direcionada para a defesa dos interesses das pessoas desprovidas de recursos financeiros, estaremos diante de uma função estritamente típica. (...) A Defensoria Pública estará desempenhando função típica sempre que a hipossuficiência do indivíduo for considerada a razão fundamentadora da intervenção institucional. Por outro lado, serão funções atípicas todas aquelas que não se relacionarem com a deficitária condição econômica do sujeito, sendo desempenhadas pela Defensoria Pública independentemente da verificação da hipossuficiência financeira do destinatário. Nesses casos, o fator econômico é irrelevante para que a Defensoria Pública possa exercer regularmente suas funções, bastando apenas que a hipótese legal de intervenção institucional esteja configurada ${ }^{131}$.

130 MORAES, Humberto Peña de; SILVA, José Fontenelle Teixeira da Silva. Assistência Judiciária: Sua Gênese, Sua História e a Função Protetiva do Estado. Rio de Janeiro: Liber Juris, 1984.

${ }^{131}$ ESTEVES; ALVES SILVA, 2017, p. 362-363. 
Entretanto, essa divisão ganha um novo cunho por conta da Emenda Constitucional $\mathrm{n}^{\circ}$ 80, que inova trazendo funções diferenciadas para a Instituição. Dessa forma, a promoção dos direitos humanos, a tutela coletiva e a garantia do regime democrático tornam-se funções típicas e as demais passam a ser atípicas. De um modo mais claro, as funções constitucionalmente previstas são consideradas como típicas, e as legalmente previstas são apreciadas como atípicas.

Importante mencionar que a Instituição não se atenta apenas para uma determinada gama de direitos, mas, pelo contrário, tende a objetivar o seu trabalho prestando assistência jurídica e amparando os direitos fundamentais de todas as dimensões, isto é, os liberais, sociais, coletivos, ambientais.

Uma das funções mais expressivas da Defensoria Pública é a prestação de orientação jurídica e a defesa dos necessitados. Pois a Instituição tem como objetivo viabilizar o amplo acesso à ordem jurídica justa, portanto, a atuação da Defensoria deve ser canalizada de forma a abranger toda e qualquer atividade tanto na esfera judicial quanto na esfera extrajudicial e administrativa ${ }^{132}$.

O art. $4^{\circ}$ da Lei Complementar no 80 , de $1994^{133}$ é o responsável por listar de forma exemplificativa as funções institucionais da Defensoria

\footnotetext{
${ }^{132}$ ESTEVES; ALVES SILVA, 2017, p. 366.

${ }^{133}$ Art. $4^{\circ}$ São funções institucionais da Defensoria Pública, dentre outras: I - prestar orientação jurídica e exercer a defesa dos necessitados, em todos os graus; II - promover, prioritariamente, a solução extrajudicial dos litígios, visando à composição entre as pessoas em conflito de interesses, por meio de mediação, conciliação, arbitragem e demais técnicas de composição e administração de conflitos; III - promover a difusão e a conscientização dos direitos humanos, da cidadania e do ordenamento jurídico; IV - prestar atendimento interdisciplinar, por meio de órgãos ou de servidores de suas Carreiras de apoio para o exercício de suas atribuições; V - exercer, mediante o recebimento dos autos com vista, a ampla defesa e o contraditório em favor de pessoas naturais e jurídicas, em processos administrativos e judiciais, perante todos os órgãos e em todas as instâncias, ordinárias ou extraordinárias, utilizando todas as medidas capazes de propiciar a adequada e efetiva defesa de seus interesses; VI - representar aos sistemas internacionais de proteção dos direitos humanos, postulando perante seus órgãos; VII - promover ação civil pública e todas as espécies de ações capazes de propiciar a adequada tutela dos direitos difusos, coletivos ou individuais homogêneos quando o resultado da demanda puder beneficiar grupo de pessoas hipossuficientes; VIII - exercer a defesa dos direitos e interesses individuais, difusos, coletivos e individuais homogêneos e dos direitos do consumidor, na forma do inciso LXXIV do art. $5^{\circ}$ da Constituição Federal; IX - impetrar habeas corpus, mandado de injunção, habeas data e mandado de segurança ou qualquer outra ação em defesa das funções institucionais e prerrogativas de seus
} 
Pública. Vale dizer que, com o ingresso da Lei Complementar $\mathrm{n}^{\circ} 132$, em 2009, esse rol se expandiu e de uma maneira bem diversificada. Pois, se antes a Instituição contava com atividades voltadas para a assistência individual de forma predominante, agora foi dado o devido mérito para a atuação em situações coletivas, revelando, dessa maneira, o caráter individual e coletivo da Defensoria na defesa dos direitos dos mais necessitados. Ademais, a Instituição agora conta também com um número maior de meios alternativos para a solução dos problemas, tentando esvair o poder judiciário em algumas situações.

Pode-se dizer, dessa forma que, a Defensoria Pública continua exercendo a sua função ordinária de defender causas individuais, tanto na esfera cível como na criminal. E pelo ponto de vista coletivo, Tiago Fensterseifer ${ }^{134}$ explica que com este viés na atuação da Instituição há um maior alcance judicial, possibilitando o enfoque da economia processual e o alcance de um número maior de pessoas através das medidas judiciais propostas. Um grande exemplo é a ação civil pública na qual, como visto anteriormente, a Defensoria Pública é uma das legitimadas a propor a ação em prol dos interesses coletivos, individuais homogêneos e difusos.

órgãos de execução; $\mathrm{X}$ - promover a mais ampla defesa dos direitos fundamentais dos necessitados, abrangendo seus direitos individuais, coletivos, sociais, econômicos, culturais e ambientais, sendo admissíveis todas as espécies de ações capazes de propiciar sua adequada e efetiva tutela; XI - exercer a defesa dos interesses individuais e coletivos da criança e do adolescente, do idoso, da pessoa portadora de necessidades especiais, da mulher vítima de violência doméstica e familiar e de outros grupos sociais vulneráveis que mereçam proteção especial do Estado; XIV - acompanhar inquérito policial, inclusive com a comunicação imediata da prisão em flagrante pela autoridade policial, quando o preso não constituir advogado; $X V$ patrocinar ação penal privada e a subsidiária da pública; XVI - exercer a curadoria especial nos casos previstos em lei; XVII - atuar nos estabelecimentos policiais, penitenciários e de internação de adolescentes, visando a assegurar às pessoas, sob quaisquer circunstâncias, o exercício pleno de seus direitos e garantias fundamentais; XVIII - atuar na preservação e reparação dos direitos de pessoas vítimas de tortura, abusos sexuais, discriminação ou qualquer outra forma de opressão ou violência, propiciando o acompanhamento e o atendimento interdisciplinar das vítimas; XIX atuar nos Juizados Especiais; XX - participar, quando tiver assento, dos conselhos federais, estaduais e municipais afetos às funções institucionais da Defensoria Pública, respeitadas as atribuições de seus ramos; XXI - executar e receber as verbas sucumbenciais decorrentes de sua atuação, inclusive quando devidas por quaisquer entes públicos, destinando-as a fundos geridos pela Defensoria Pública e destinados, exclusivamente, ao aparelhamento da Defensoria Pública e à capacitação profissional de seus membros e servidores; XXII - convocar audiências públicas para discutir matérias relacionadas às suas funções institucionais.

${ }^{134}$ FENSTERSEIFER, 2017, p. 69. 
Em razão das novas práticas extrajudiciais consagradas pela Lei Complementar $n^{\circ} 132$, fica fácil perceber que há uma tendência a solucionar os conflitos por meio de resoluções fora do âmbito judicial. Além disso, o Novo Código de Processo Civil também incentiva essa prática, gerando um maior destaque para essa atividade. Um grande exemplo dessa atuação é o inciso II do art. $4^{\circ}$, que estimula e dá competência para a Instituição resolver os potenciais problemas por meio da conciliação, mediação e arbitragem. O parágrafo $4^{\circ}$ do mesmo dispositivo só reforça essa ideia ao dispor que o instrumento referendado pelo Defensor Público, após essas técnicas extrajudiciais, valerá como título executivo extrajudicial, inclusive quando celebrado com pessoa jurídica de direito público.

Por conta disso, seguindo a posição de Tiago Fenterseifer ${ }^{135}$, a Defensoria Pública tem a tarefa de evitar ao máximo as demandas judiciais, buscando sempre que possível a resolução por meio de recursos adequados, amigáveis e extrajudiciais.

Outro exemplo dessa prática é o fato da Instituição ser responsável por promover a difusão e a conscientização dos direitos humanos, da cidadania e do ordenamento jurídico (art $4^{\circ}$, inciso III, da LC $\mathrm{n}^{\circ} 80$ ). Isso quer dizer que a Defensoria Pública cumpre um papel de extrema relevância ao disponibilizar formas de transferir conhecimento à sociedade, pois muitas vezes as classes menos beneficiadas da população não conhecem a Constituição, as leis e todos os direitos que delas decorrem, necessitando, assim, de uma educação jurídica. $\mathrm{O}$ autor informa que a partir dessa missão há um incentivo para um crescimento democrático no Brasil, isto é, há uma contribuição para a "própria inserção político-comunitária dos indivíduos e grupos sociais necessitados", assegurando a tais pessoas o exercício do seu "status político-jurídico de cidadão", de modo que, em determinadas

\footnotetext{
${ }^{135}$ FENSTERSEIFER, 2017, p. 70-71.
} 
circunstâncias, tenham condições de reivindicar seus direitos, até mesmo por conta própria ${ }^{136}$.

Além do papel já descrito, a Defensoria Pública cumpre função significativa na seara penal ao defender o direito à liberdade. Tal atuação "assegura o exercício dos direitos liberais especialmente em face de violações e arbitrariedades levadas a cabo pelo próprio Estado e seus agentes" ${ }^{137}$. Vale dizer que os direitos liberais não são defendidos apenas no âmbito individual, podendo ser amparados pela Instituição com um viés coletivo, e uma amostra desse exercício é o fato da Defensoria Pública lutar por melhorias no sistema prisional em virtude da coletividade.

A Defensoria Pública também direciona o seu funcionamento para a proteção dos direitos sociais, como observa Tiago Fensterseifer:

\footnotetext{
Hoje o seu papel constitucional com grande potencial de transformação social e construção de uma sociedade livre, justa e igualitária está relacionado à tutela e promoção dos direitos fundamentais sociais. Trata-se de assegurar aos indivíduos e grupos sociais necessitados o desfrute dos bens sociais elementares, ou seja, de um nível de bem-estar individual e social compatível com uma vida digna (em termos de prestações sociais fornecidas pelo Estado). É a inclusão das pessoas necessitadas no pacto social que está em jogo em tal mister institucional ${ }^{138}$.
}

Ainda nesse aspecto funcional da Defensoria Pública, é preciso esclarecer a diferença nas atuações da Defensoria Pública da União e dos Estados. Sabe-se que a Instituição é uma só, assim como foi visto nos tópicos anteriores, entretanto, existem áreas de atuação diversas. A Defensoria da União atua nos graus e instâncias administrativas federais, isto é, junto à Justiça Federal, Justiça do Trabalho, Justiça Eleitoral, Tribunais Superiores e instâncias administrativas da União. Por outro lado, as Defensorias Estaduais estão vinculadas à estrutura estadual ${ }^{139}$.

\footnotetext{
${ }^{136}$ FENSTERSEIFER, 2017, p. 71-77.

${ }^{137}$ Ibid., p. 93.

138 Ibid., p. 104.

139 BRASIL. Tribunal de Justiça do Estado do Amapá. Disponível em: <http://www.tjap.jus.br/portal/66-tjap/corregedoria/faq/166-qual-e-a-diferenca-entre-a-defensoriapublica-da-uniao-e-as-defensorias-publicas-estaduais.html>. Acesso em: 05 mai. 2018.
} 
Pode-se, então, perceber que a Instituição possui diversas funções especificadas no rol exemplificativo do art. $4^{\circ}$ da Lei Complementar $n^{\circ} 80$. E que todas elas são de extrema significância para a consagração do acesso à justiça de forma plena, adequada e satisfatória. 


\section{CAPÍTULO 3 - A DEFENSORIA PÚBLICA E O SEU PAPEL NA PROMOÇÃO E DESENVOLVIMENTO DO ACESSO À JUSTIÇA}

Ao longo dos capítulos anteriores, foi possível perceber que o Acesso à Justiça é um direito que, quando consagrado e respeitado, possibilita a tutela de todos os demais. A ideia do princípio da dignidade da pessoa humana está completamente interligada com a efetividade da assistência jurídica proporcionada pelo Estado aos mais necessitados, pois é ele que está na base de todos os direitos constitucionalmente reconhecidos.

Ao tratar de um dos objetivos fundamentais da República Federativa do Brasil - a dignidade da pessoa humana - pode-se afirmar que, um Estado Democrático de Direito não tem como funcionar de forma minimamente adequada se os direitos, ao menos em patamares mínimos, não forem devidamente respeitados. Com isso, é plausível afirmar que o êxito de um regime democrático depende da garantia de um conjunto mínimo de direitos a todos os cidadãos ${ }^{140}$.

Muitos autores questionam o que realmente seria este princípio, pois não há um conceito puro e simples capaz de descrevê-lo totalmente. Ana Paula de Barcellos diz que para solucionar este problema é preciso ter em mente que, a sociedade não pode ser incapaz de reconhecer quando as pessoas se encontram em condições indignas, ou seja, se não houver consenso a respeito de um conteúdo mínimo da dignidade, estar-se-á diante de uma crise ética e moral, pois se não é possível vislumbrar situações de indignidade não se poderá conhecer mais a noção da própria dignidade ${ }^{141}$.

A partir disso, muitos começaram a disseminar a concepção de um mínimo existencial, de forma a ilustrar o que seriam essas condições

\footnotetext{
${ }^{140}$ BARCELlOS, Ana Paula de. A Eficácia Jurídica dos Princípios Constitucionais. O princípio da Dignidade da Pessoa Humana. $3^{a}$ ed. São Paulo: Renovar, 2011. p. 175.

${ }^{141}$ Ibid., p. 246-247.
} 
mínimas que compõem a dignidade da pessoa humana. Mas com isso, surgem também novos questionamentos sobre o conteúdo deste mínimo existencial. Para Ana Paula de Barcellos:

É o conjunto de situações materiais indispensáveis à existência humana digna; existência aí considerada não apenas como experiência física - a sobrevivência e a manutenção do corpo - mas também espiritual e intelectual, aspectos fundamentais em um Estado que se pretende, de um lado, democrático, demandando a participação dos indivíduos nas deliberações públicas, e, de outro, liberal, deixando a cargo de cada um seu próprio desenvolvimento ${ }^{142}$.

Sem o acesso às condições existenciais mínimas, não há como falar em um padrão de vida compatível com a dignidade da pessoa humana. Para Ricardo Lobo Torres, "sem o mínimo necessário à existência, cessa a possibilidade de sobrevivência do homem e desaparecem as condições iniciais da liberdade" ${ }^{143}$. Além disso, tratar do direito ao mínimo existencial é abordar o fato de que o Estado deve ter respeito e consideração pela vida de cada indivíduo, atuando para a realização e concretização da dignidade da pessoa humana, principalmente daqueles que estão em condição de vulnerabilidade e dependem da intervenção estatal para obterem os seus direitos fundamentais ${ }^{144}$.

O conteúdo deste mínimo existencial é caracterizado por ter um núcleo irredutível, porém, não é possível defini-lo de modo exato. Tiago Fensterseifer exemplifica o que ele seria, explicando que é um direito autônomo, mas, ao mesmo tempo, encontra respaldo e se constitui por meio de outros direitos fundamentais, como, por exemplo: a saúde, educação, moradia, alimentação, saneamento básico, assistência e previdência social, etc. Por conta disso, será sempre imprescindível analisar o caso concreto para identificar o grau de violação à dignidade da pessoa humana ${ }^{145}$.

\footnotetext{
142 BARCELLOS, 2011, p. 247.

${ }^{143}$ TORRES, Ricardo Lobo. $O$ direito ao mínimo existencial. Rio de Janeiro: Renovar, 2009. p. 36.

${ }^{144}$ FENSTERSEIFER, 2017, p. 198-199.

${ }^{145}$ Ibid., p. 199-200.
} 
Por meio da exposição acerca do direito fundamental ao mínimo existencial é possível dizer que há uma forte conexão com o acesso à justiça, de modo a afirmar que ele "é um dos componentes do núcleo da dignidade da pessoa humana"146

Nos moldes de Tiago Fensterseifer:

$\mathrm{O}$ acesso à justiça ou ao direito fundamental das pessoas necessitadas à assistência jurídica, por sua vez, configura-se como "elemento instrumental" do direito fundamental ao mínimo existencial, já que o conteúdo dos demais direitos fundamentais que compõem o mínimo existencial, resultariam completamente esvaziados sem a possibilidade de as situações concretas de violações ou ameaças de violações a tais direitos serem levadas ao Poder Judiciário ${ }^{147}$.

Por consequência, pode-se dizer que o acesso à justiça é o instrumento por meio do qual os direitos que integram o mínimo existencial poderão ser alcançados e materializados. Com isso, este direito fundamental a uma assistência jurídica aos necessitados, é denominado por muitos como "direito a ter direitos" ou "direito a ter direitos efetivos"148. Através do ensinamento de Ronnie Preuss Duarte, essas denominações são justificadas, pois sem o acesso à justiça torna-se impensável a reparação das violações aos direitos fundamentais. Ou seja, os direitos e interesses subjetivos, sem qualquer condição mínima de praticabilidade, acabam convertendo-se em meras proclamações formais ${ }^{149}$.

É preciso pensar no acesso à justiça como um serviço público essencial para as pessoas necessitadas, de modo a concretizar o princípio da igualdade e possibilitar condições reais de proporcionalidade ${ }^{150}$. Nesse sentido, surge a Defensoria Pública com o papel fundamental de ampliação deste acesso, com a função de tornar acessível às pessoas carentes a efetivação dos direitos fundamentais, lhes assegurando uma vida digna por meio da assistência e orientação jurídica integral e gratuita. Vale dizer que o

\footnotetext{
${ }^{146}$ BARCELLOS, 2011, p. 341.

${ }^{147}$ FENSTERSEIFER, 2017, p. 201.

148 Ibid., p. 201-202.

${ }^{149}$ DUARTE, Ronnie Preuss. Garantia de Acesso à Justiça: os direitos processuais fundamentais. Coimbra: Coimbra Editora, 2007. p. 86.

${ }^{150}$ FENSTERSEIFER, op. cit., p. 168.
} 
Estado deve arcar com essa responsabilidade e preocupar-se em estabelecer essas Instituições de maneira forte e ativa, pois se não agir desta forma estará praticando uma inconstitucionalidade ${ }^{151}$. Para Cleber Francisco Alves:

\begin{abstract}
Não se trata apenas de um dever de cunho social, voltado para a promoção do bem-estar e para a erradicação da pobreza, embora este seja um dos objetivos de caráter geral expressamente estabelecido no art. $3^{\circ}$ da Constituição brasileira. Trata-se, na verdade, de um dever estatal inerente ao próprio exercício da cidadania, que não pode ser afetado em razão de restrições referentes a prioridades orçamentárias ${ }^{152}$.
\end{abstract}

O Estado então, deve fornecer e ampliar a assistência jurídica, tendo em vista a disseminação de um sistema justo, coeso e paritário, preconizando a justiça. E é por meio da Defensoria Pública que esta atividade pode ser desempenhada com sucesso, pois a Instituição foi criada e pensada, exclusivamente, para garantir o acesso à justiça aos mais vulneráveis na sociedade, conferindo-lhes igualdade e dignidade. Assim:

É preciso ter presente que a atuação dos Defensores vai muito além da mera postulação perante o Judiciário: deve abranger atuação perante órgãos da administração pública, que ainda é muito deficiente na grande maioria das Defensorias Públicas do país; e isto não apenas em defesas de acusados em processos disciplinares, mas também de uma maneira pró-ativa e criativa mediante toda e qualquer intervenção que possa resultar em preservação e ampliação de direitos e benefícios legalmente admissíveis em prol do cidadão, no campo da educação, saúde pública, moradia, e assistência social; deve abranger também a atuação em âmbito parlamentar, na busca do aprimoramento das leis que afetam diretamente os interesses dos mais pobres, assim como na conquista de novas garantias e benefícios legais capazes de contribuir para a erradicação da pobreza e a melhoria das condições de vida daqueles que são os destinatários da atuação da Defensoria Pública. Trata-se de garantir o Acesso à Justiça em sentido amplo, para todos, e em sentido pleno, integral, como determina a Constituição de $1998^{153}$.

Contudo, apesar dos esforços e avanços da Defensoria Pública, é nítido vislumbrar algumas dificuldades enfrentadas ao longo dos anos. Por meio deste terceiro capítulo será possível expor alguns dos principais problemas enfrentados pela Instituição nos dias atuais, como também

\footnotetext{
${ }^{151}$ FENSTERSEIFER, 2017, p. 170.

${ }^{152}$ ALVES, 2006, p. 260.

153 Ibid., p. 321.
} 
pensar em soluções concretas para aprimorar e melhorar a sua atuação "para o bem da nossa democracia e, principalmente, da proteção dos direitos dos mais necessitados" ${ }^{154}$.

\subsection{Problemas enfrentados pela Defensoria Pública que dificultam a efetividade do Acesso à Justiça}

É de extrema relevância tentar apreciar o quadro da Defensoria Pública. Isso porque é necessário perceber quais são as maiores adversidades e impedimentos que prejudicam o acesso à justiça no Brasil, para que assim seja possível trabalhar com soluções que possam torná-lo mais amplo e efetivo, em prol daqueles considerados como mais frágeis na sociedade.

Márcio Thomaz Bastos acredita que o grande desafio, atualmente, é solidificar as instituições democráticas capazes de propiciar a realização do que foi consagrado na Constituição. E para ele, a Defensoria Pública é a instituição que tem por objetivo a concretização do acesso à justiça, sendo que este é um dos maiores obstáculos a ser solucionado, pois é vital no processo de efetivação de direitos ${ }^{155}$.

Cleber Francisco Alves expõe de forma clara que dentre os Estados da Federação, poucas são as Defensorias Públicas que se assemelham ao modelo estabelecido na Constituição Federal. E, mesmo nos Estados em que as Instituições estão funcionando e atuando, é notável perceber dificuldades de ordem funcional e operacional. Muito em virtude do número insuficiente de defensores públicos, ou seja, em razão da falta de condições materiais para atividade. Vale dizer que o cenário fica ainda mais alarmante em âmbito federal, pois a quantidade de defensores públicos da

\footnotetext{
154 IV Diagnóstico da Defensoria Pública no Brasil. p. 8. Disponível em: $<$ https://www.anadep.org.br/wtksite/downloads/iv-diagnostico-da-defensoria-publica-nobrasil.pdf $>$. Acesso em: 10 mai. 2018.

${ }^{155}$ Apresentação do Estudo Diagnóstico da Defensoria Pública no Brasil. p. 132. Disponível em: <https://www.anadep.org.br/wtksite/downloads/Diag_defensoria.pdf>. Acesso em: 10 mai. 2018.
} 
União é ínfima, o que impede que a Defensoria Pública siga as suas atribuições legais e constitucionais ${ }^{156}$.

Por conta disso, é interessante fazer uma divisão entre as Defensorias Públicas Estaduais e Federais, e analisá-las de forma apartada, para facilitar a compreensão do cenário vigente. Mas antes de distingui-las, é considerável citar aqui, novamente, uma emenda que irá nortear o estudo.

A Emenda Constitucional $\mathrm{n}^{\circ}$ 80, de 2014, é a responsável por implementar o dever estatal de ampliação progressiva do serviço de assistência jurídica por meio da criação e expansão da Defensoria Pública. Esta emenda acrescentou aos Atos das Disposições Constitucionais Transitórias, o artigo 98, impondo que "o número de defensores públicos na unidade jurisdicional será proporcional à efetiva demanda pelo serviço da Defensoria Pública e à respectiva população". Além disso, nos parágrafos do dispositivo, há o dever de que, no prazo de oito anos, todas as unidades jurisdicionais tenham defensores públicos, prioritariamente nas regiões com maiores índices de exclusão social e adensamento populacional.

Tendo em conta este encargo constitucional, os entes da Federação passam a ser responsáveis pela prestação da assistência jurídica, possuindo como incumbência a adoção de medidas capazes de surtir efeitos positivos e efetivos na Instituição. Tiago Fensterseifer ${ }^{157}$ cita a omissão estatal, tanto por parte do Poder Legislativo quanto do Poder Executivo, é injustificável, caracterizando descumprimento flagrante da norma constitucional, sendo passível até mesmo a intervenção judicial para fazer valer a força normativa da Constituição.

A partir dessa exposição, um dos mais notáveis impedimentos para uma boa assistência jurídica, capaz de impulsionar o acesso à justiça, é percebido por meio do IV Diagnóstico da Defensoria Pública no Brasil, que revela de forma expressa que, no país existem muito mais juízes e

\footnotetext{
${ }^{156}$ ALVES, 2006, p. 234.

${ }^{157}$ FENSTERSEIFER, 2017, p. 15; 189.
} 
promotores de justiça do que defensores públicos. Dessa forma, fica claro que há uma ausência latente de Defensorias Públicas em muitas comarcas e uma quantidade inferior de defensores públicos, isto faz com que o "estadojuiz" e o "estado-acusação" atuem de forma muito mais ampla e palpável do que o "estado-defesa", impossibilitando a salvaguarda dos interesses da parcela da população mais carente ${ }^{158}$.

O defensor público Cleber Francisco Alves, no seu livro "Justiça para Todos", expõem outros problemas e obstáculos gerais da Defensoria Pública. Um primeiro aspecto citado por ele diz respeito à impossibilidade de escolha, pelo cliente, do defensor que patrocinará a sua causa e seus interesses. Segundo o autor isso impede, muitas vezes, a formação de um vínculo pessoal de confiança entre o cliente e o Defensor Público. Por outro lado, ele acredita que os concursos públicos asseguram a formação de um corpo de profissionais muito competente. Além disso, muito dificilmente os clientes conseguiriam, com os seus próprios recursos, contratar um advogado particular no mesmo nível e com a mesma capacitação ${ }^{159}$.

Um outro aspecto que costuma demonstrar-se como frágil é a questão da independência e autonomia dos profissionais integrantes da carreira. Cleber Francisco Alves diz que:

Na medida em que são funcionários do Estado, contra o qual muitas vezes terão de litigar na defesa de interesses de seus assistidos; para neutralizar essa possível fragilidade, o sistema normativo legal e constitucional brasileiro estabeleceu uma série de garantias destinadas a assegurar plena autonomia e independência funcional tanto do órgão estatal como um todo, perante os demais Poderes formais do Estado, como também de cada Defensor Público em particular, na sua atuação funcional em defesa dos seus assistidos; há, todavia, o risco de que essas garantias acabem provocando atitudes de acomodação nos profissionais integrantes da carreira, o que somente poderá ser evitado com um trabalho sério de fiscalização dos órgãos institucionais competentes e pela valorização de uma consciência ética comprometida com a missão própria da instituição, notadamente na fase de avaliação do estágio probatório ${ }^{160}$.

\footnotetext{
${ }_{158}$ IV Diagnóstico da Defensoria Pública no Brasil. p. 12. Acesso em: 10 mai. 2018.

${ }^{159}$ ALVES, 2006, p. 352.

${ }^{160}$ Ibid., p. 352-353.
} 
Outro problema observado pelo Defensor Público está pautado no fato de que há:

\begin{abstract}
Falta de investimentos adequados e necessários para o pleno funcionamento das Defensorias, sobretudo, o tratamento desigual e discriminatório conferido à instituição em confronto com as demais carreiras jurídicas; também é grave a sobrecarga de trabalho resultante da existência de uma demanda muito superior à capacidade dos órgãos de atuação; outrossim, deve ser consignado o problema relativo às precárias condições de funcionamento, visto que não raro as Defensorias estão instaladas em locais insalubres, não possuem equipamentos e mobiliário necessários às suas atividades, não contam com quadro de pessoal de apoio, além da falta de Defensores Públicos em quantitativo suficiente; esse quadro gera uma sensação dramática de falta de qualidade na prestação de serviços, sobretudo na perspectiva do cliente, que muitas vezes tem que esperar horas para ser atendido; isto é uma realidade, em que pese a reconhecida qualidade técnica das intervenções processuais dos Defensores Públicos, fato que é sistematicamente reconhecido pelos integrantes das demais profissões jurídicas ${ }^{161}$.
\end{abstract}

Tendo essas informações como base, é pertinente citar aqui que o IV Diagnóstico, publicado no dia 18 de dezembro de 2015, será uma ferramenta de grande auxílio para a monografia e para o real conhecimento, de forma mais específica, da conjuntura da Defensoria Pública dos Estados e da União.

\title{
3.1.1 As Defensorias Públicas Estaduais e seus maiores desafios
}

Primeiramente, já é possível perceber que a história e a instituição das Defensorias Públicas Estaduais são bem distintas uma das outras. A mais antiga delas é a do Estado do Rio de Janeiro, criada em 1954, antes mesmo da Constituição Federal de 1988. Por outro lado, existem Defensorias instituídas muito recentemente no sistema jurídico brasileiro. Um grande exemplo disso é a Defensoria Pública de Santa Catarina, institucionalizada apenas no ano de 2012 162 . Ademais, "a diversidade que permeia as Defensorias Públicas vai além da sua institucionalização, a

\footnotetext{
${ }^{161}$ ALVES, 2006, p. 353.

${ }^{162}$ IV Diagnóstico da Defensoria Pública no Brasil. p. 18. Acesso em: 10 mai. 2018.
} 
começar pela composição do perfil e das percepções dos defensores públicos do estado que as compõem"163.

A primeira característica observada em relação à composição dos defensores públicos estaduais demonstra que $51 \%$ são do sexo masculino, enquanto que 49\% são do sexo feminino. Em relação à idade, os defensores que têm até 40 anos chegam a compor $64,3 \%$ das vagas, enquanto que menos de 5\% são compostas por pessoas com mais de 60 anos de idade. $\mathrm{O}$ IV Diagnóstico justifica essa diferença etária explicitando que, em muitos Estados a Defensoria Pública é uma Instituição muito recente. Além disso, o documento propõe que seja feito um estudo para que outros motivos sejam revelados. No tocante à cor/raça, mais de $75 \%$ dos defensores foram considerados brancos. Isso faz com que seja necessária uma reflexão a respeito da exclusão de determinados grupos da sociedade, de forma a combater a desigualdade social no interior das Instituições ${ }^{164}$.

Muito se questiona também sobre os reais motivos que impulsionaram os defensores públicos a exercer tal estimada carreira. Mais de $91 \%$ dos entrevistados no IV Diagnóstico da Defensoria Pública citaram o interesse pelo trabalho social como uma das principais razões motivacionais. Em contrapartida, a estabilidade e a remuneração também foram fatores importantes que influenciaram os defensores a ingressar na carreira pública ${ }^{165}$.

A maior parte dos defensores acredita que para trabalhar na Instituição é necessário considerar alguns fatores, como por exemplo: o saber técnico-jurídico e a independência funcional, assim como o comprometimento com os princípios institucionais, com a justiça social e com a comunidade socialmente vulnerável ${ }^{166}$. Isso explicita que a vocação para causas sociais e humanitárias é extremamente determinante para a boa prestação do serviço público por parte dos membros da Defensoria Pública.

\footnotetext{
${ }^{163}$ IV Diagnóstico da Defensoria Pública no Brasil. p. 19. Acesso em: 10 mai. 2018.

${ }^{164}$ Ibid., p. 20.

${ }^{165}$ Ibid., p. 21.

${ }^{166}$ Ibid., p. 22.
} 
A respeito da atuação das Defensorias Estaduais, predomina o entendimento de que elas têm conseguido cumprir os seus objetivos. 25,1\% dos defensores concordaram totalmente com esta afirmação. Enquanto que outros 56,2\% concordam apenas de forma parcial. Em contraposição, a atuação dos defensores públicos foi mais aclamada, tendo 59\% confirmado que os profissionais são dotados e preparados para exercerem a suas funções. Ainda sobre este cenário, apenas $20 \%$ dos defensores estaduais acreditam que a relação da Defensoria Pública com as outras instituições do Sistema de Justiça ocorre de forma plena ${ }^{167}$, demonstrando então que esta situação encontra-se numa posição bem negativa.

Um dos grandes obstáculos para o acesso à justiça está pautado na atuação do próprio Poder Judiciário. Aos olhos dos defensores públicos, um primeiro problema seria a falta de integração entre as instituições do sistema de justiça brasileiro, como falado acima. O segundo estaria voltado ao excesso de formalismo, o que impediria o diálogo entre as partes e um bom fornecimento de informações e até mesmo de educação jurídica para os hipossuficientes. O terceiro problema situa-se no próprio ensino superior, ou seja, no ensino jurídico tecnicista e na sua má qualidade. Assim, pode-se dizer que a Defensoria Pública deve ser um agente capaz de questionar tais práticas e situações, tentando inverter a realidade destes quadros em prol dos mais necessitados ${ }^{168}$.

Além do exposto, foi visto no capítulo dois que, por meio da Emenda Constitucional $\mathrm{n}^{\circ}$ 45, responsável pela Reforma do Poder Judiciário, foi conferida às Defensorias Públicas Estaduais, autonomia funcional, administrativa e orçamentária, nos limites estabelecidos pela Lei de Diretrizes Orçamentárias. Entretanto, há ainda um longo caminho para que essas autonomias sejam realmente concretizadas. E este é um ponto muito sensível, pois impede a atuação e o desempenho institucional da

\footnotetext{
${ }^{167}$ IV Diagnóstico da Defensoria Pública no Brasil. p. 23. Acesso em: 10 mai. 2018.

${ }^{168}$ Ibid., p. 24.
} 
Defensoria, limitando as possibilidades de seu planejamento estratégico e da sua expansão ${ }^{169}$.

Em 2014, o Tesouro Federal contribuiu com quase $75 \%$ dos orçamentos das Defensorias Públicas Estaduais e os Fundos Próprios compostos majoritariamente pelos honorários de sucumbência, pelas taxas de inscrição de concursos públicos e pelas custas e emolumentos extrajudiciais - foram responsáveis por $22 \%$ dos cofres dessa Instituição. As que receberam mais recursos, neste ano, foram as Defensorias do Rio de Janeiro, São Paulo, Rio Grande do Sul e Minas Gerais. E as que receberam menores volumes foram as do Acre, Piauí, Rio Grande do Norte, Santa Catarina e Sergipe ${ }^{170}$. Dessa forma, fica bem nítido que a distribuição orçamentária é totalmente desigual entre as Instituições, prejudicando a igualdade entre os juridicamente mais vulneráveis e afetando o próprio acesso à justiça.

Além disso, falando ainda sobre a autonomia financeira, percebe-se que as Defensorias Estaduais ficaram mais participativas no que tange à elaboração de propostas legislativas orçamentárias. No entanto, estas formulações não significam uma garantia de que serão aceitas pelos Poderes Legislativo e Executivo estaduais. O IV Diagnóstico da Defensoria Pública revela que apenas 34,8\% tiveram propostas aprovadas sem nenhum veto, o que demonstra que há ainda uma dependência muito forte dos Executivos estaduais, limitando, assim, a atuação da Instituição. Com isso, fica clara a necessidade de estreitamento dos diálogos e de trocas de informações entre as Instituições e os Governos Estaduais ${ }^{171}$.

Vale dizer que as Defensorias Públicas Estaduais tendem a ter despesas anuais por conta das folhas de pagamento, itens de investimento e de custeio, convênios, terceirização, dentre outras coisas ${ }^{172}$. Dessa forma, é de suma relevância que a Instituição saiba organizar da melhor maneira o

\footnotetext{
${ }^{169}$ IV Diagnóstico da Defensoria Pública no Brasil. p. 28. Acesso em: 10 mai. 2018.

${ }^{170}$ Ibid., p. 28-29.

${ }^{171}$ Ibid., p. 31-32.

${ }^{172}$ Ibid., p. 37.
} 
seu orçamento e que os Poderes Executivo e Legislativo percebam a importância que a Defensoria Pública possui no ordenamento jurídico brasileiro, possibilitando mais recursos e investimento financeiro.

Em relação à autonomia funcional, que é a liberdade de atuação profissional, 93\% dos Defensores Públicos Estaduais demonstram que possuem muita ou total autonomia para atuarem como agentes do acesso à justiça, até mesmo quando o hipossuficiente traz uma questão que se dá contra o Estado ou contra a União ${ }^{173}$.

Quanto à autonomia política, 70\% dos defensores indicaram que são autônomos em relação ao Executivo Nacional, bem como ao Legislativo Nacional. Contudo, o assunto muda quando se fala nos Executivos Estaduais, sendo o percentual de apenas 43\%. Goiás, Santa Catarina, Paraíba, Piauí e Paraná são as unidades que possuem a menor autonomia em relação aos Executivos estaduais ${ }^{174}$.

Com isso, a autonomia funcional é percebida por maior parte dos defensores públicos, entretanto, as independências financeira e política ainda precisam ser perseguidas. De acordo com o IV Diagnóstico da Defensoria Pública, uma hipótese para concretizar essa autonomia seria por meio da participação popular, isto é, seria necessário um olhar comunitário para este tema. "Desse modo, todas as medidas que puderem ser tomadas, para garantir a autonomia dos Defensores Públicos, para a realização plena dos princípios e objetivos da instituição, são essenciais" ${ }^{175}$.

Ainda falando sobre autonomia, Cleber Francisco Alves diz:

Espera-se que os efeitos práticos da Emenda Constitucional no 45/2004 venham rapidamente mudar esse panorama, permitindo, enfim, a efetiva implementação da autonomia administrativa e financeira das Defensorias Públicas. É preciso um

\footnotetext{
${ }^{173}$ IV Diagnóstico da Defensoria Pública no Brasil. p. 38. Acesso em: 10 mai. 2018.

${ }^{174}$ Ibid., p. 41-42.

${ }^{175}$ Ibid., p. 43-44.
} 
esforço interpretativo de cunho progressista, para que essa garantia de autonomia não fique apenas no mundo das abstrações e das ideias ${ }^{176}$.

Um dos assuntos mais importantes neste tópico diz respeito ao número de Defensorias Públicas existentes em cada Estado, já que "o acesso à justiça gratuita por parte da população necessitada depende, em larga medida, da capacidade de organização de cada Defensoria Pública Estadual" ${ }^{177}$.

Em 2014, o número de comarcas em todo o Brasil alcançava o montante de 2.727, tendo como existentes apenas 1.088 Defensorias Públicas, o que significa dizer que apenas $40 \%$ dessas comarcas possuíam a Instituição como um agente do acesso à justiça, desrespeitando, dessa forma, o comando constitucional instituído pela Emenda $\mathrm{n}^{\circ}$ 80. As piores situações estão concentradas nos Estados de Goiás, Bahia, Rio Grande do Norte, Paraná e São Paulo ${ }^{178}$. Além disso, "no Brasil, em 2014, as Defensorias Públicas Estaduais estiveram presentes em, aproximadamente, $13 \%$ das unidades jurisdicionais". Portanto, as unidades federativas precisam avançar seus esforços para atender de forma completa a $\mathrm{EC} \mathrm{n}^{\circ}$ $80^{179}$.

"Em 14 estados brasileiros, mais de 90\% dos defensores públicos afirmaram que ainda falta muito para que as Defensorias em que atuam cumpram a meta estabelecida pela EC"180. Tudo isso ressalta um cenário bem complicado para a maioria dos estados brasileiros e, principalmente, para a concretização do acesso à justiça e para a culminância de maiores desigualdades sociais e econômicas.

O número de defensores públicos atuantes também é preocupante, principalmente, nos Estados do Acre e Sergipe, onde não ocorreram ganhos de servidores, pelo contrário, ocorreram perdas. Assim como em São Paulo,

\footnotetext{
${ }^{176}$ ALVES, 2006, p. 311-312.

177 IV Diagnóstico da Defensoria Pública no Brasil. p. 58. Acesso em: 10 mai. 2018.

${ }^{178}$ Ibid., p. 59-60.

${ }^{179}$ Ibid., p. 61-62.

${ }^{180}$ Ibid., p. 64.
} 
onde há uma baixa proporção de membros atuantes. As unidades da Federação que possuem os maiores números de Defensores Públicos por tamanho da população-alvo são Rio Grande do Norte e o Distrito Federal. Enquanto que as situações mais dramáticas são encontradas nos Estados do Paraná e de Santa Catarina ${ }^{181}$.

Além do número de defensores públicos, quase metade das unidades não possuem servidores que desenvolvam atividades administrativas e $62,5 \%$ não contam com quadro próprio de servidores de apoio. Por outro lado, a disponibilidade de estagiários se revela maior em grande parte das Defensorias. O IV Diagnóstico revela que é necessária a interdisciplinaridade para a garantia do acesso à justiça, pois ela é capaz de assegurar o conhecimento prático e científico ${ }^{182}$. Consta citar que, o número de Defensorias que contam com defensores e servidores substitutos também é baixo, comprometendo assim, o trabalho da Instituição. Ademais, há ausência de convênios ou de acordos de colaboração com entidades capazes de auxiliar o trabalho da Defensoria, o que acaba acarretando numa grande dificuldade em alcançar a interdisciplinaridade no exercício das suas funções e numa sobrecarga para os defensores públicos estaduais que acabam tendo responsabilidades de maneira excessiva ${ }^{183}$. Dessa forma, é preciso não só de aumento da remuneração dos servidores (o que é muito importante), mas também de investimento, de uma maneira geral, para que o trabalho seja feito adequadamente ${ }^{184}$.

A qualificação, capacitação e o aperfeiçoamento do pessoal devem ser realizados para que ocorra um desenvolvimento profissional em prol do melhor acesso à justiça. 70,8\% das Defensorias contam com centro de estudos ou escola jurídica própria. São entidades que possuem como intuito a disseminação do conhecimento a respeito da assistência jurídica e atualização jurídica dos defensores que já são atuantes. Entretanto, é

\footnotetext{
${ }^{181}$ IV Diagnóstico da Defensoria Pública no Brasil.p. 45-46. Acesso em: 10 mai. 2018.

${ }^{182}$ Ibid., p. 46.

${ }^{183}$ Ibid., p. 64.

${ }^{184}$ Ibid., p. 51.
} 
pequeno o número de defensores que participam das capacitações fornecidas e custeadas pela própria Instituição. O IV Diagnóstico sugere que sejam atribuídos pontos para essas atividades na evolução dos planos de carreira, para que, assim, haja um bom estímulo para a participação mais efetiva dos servidores. Além disso, o relatório defende que o próprio defensor público precisa se sensibilizar para sua melhor capacitação, até mesmo por conta de uma questão ética profissional ${ }^{185}$.

Outro aspecto relevante é a questão do acesso físico nas unidades da Defensoria Pública, isto é, a mobilidade é um outro fator preocupante. Segundo o IV Diagnóstico, 17,8\% dos defensores públicos trabalham em locais que não podem ser facilmente acessados por aqueles que dependem do transporte público, e 35,9\% estão em locais não preparados e dispostos a atender pessoas com restrições físicas. Por isso, esse é um outro problema que impede o efetivo atendimento àqueles que mais precisam de auxílio ${ }^{186}$.

Além da mobilidade que é extremamente dificultada pelo mau planejamento, a estrutura interna das Defensorias Públicas também é alarmante. "A deficiência na prestação da assistência jurídica gratuita por conta da inadequada estrutura das Defensorias Públicas Estaduais compromete fortemente o gozo do direito fundamental de acesso à justiça aos hipossuficientes" ${ }^{187}$. 88,7\% contam com gabinete para trabalho, sendo $49 \%$ individual e $39,7 \%$ coletivo, o que denota que existem Instituições sem espaço adequado para a prestação do serviço, o que prejudica, automaticamente, o acesso à justiça.

Além disso, a qualidade do local e o material de trabalho também são fatores que influenciam a atividade da Defensoria Pública. Pode-se dizer que, a falta de "telefones, computadores, fax, impressoras, estrutura de rede e acesso à internet, sistema informatizado, material de expediente, serviço de limpeza, mobiliário e infraestrutura física" prejudica a dinâmica e a

\footnotetext{
${ }^{185}$ IV Diagnóstico da Defensoria Pública no Brasil. p. 54-56. Acesso em: 10 mai. 2018.

${ }^{186}$ Ibid., p. 66.

187 Ibid., p. 66.
} 
celeridade do atendimento aos assistidos, impossibilitando a eficácia da atuação dos defensores públicos, servidores administrativos, substitutos e estagiários ${ }^{188}$.

Outro grande embate da Defensoria Pública está pautado no fato de que a quantidade de convênios celebrados pela Instituição é ainda muito baixa. " $74 \%$ dos defensores públicos estaduais declaram que sua instituição não mantém convênio com outras instituições para a prestação de assistência jurídica gratuita"189. O IV Diagnóstico da Defensoria Pública explicita que dentre as entidades conveniadas, destacam-se as Universidades e Faculdades de Direito e a própria OAB. Além disso, " $80 \%$ dos defensores públicos atuam em unidades que não mantêm parcerias com outras instituições para encaminhamento dos casos que não são cobertos" ${ }^{190}$.

Um ponto positivo e de desenvolvimento por parte da Defensoria Pública encontra respaldo na sua atuação extrajudicial. 85\% dos defensores que participam do IV Diagnóstico da Defensoria Pública afirmaram que a unidade em que atuam realiza esse tipo de serviço. Ademais, a grande maioria dos defensores públicos estaduais opta, sempre ou na maioria das vezes, pelo uso de formas extrajudiciais de resolução de $\operatorname{conflitos}^{191}$.

Um fato que chama a atenção no presente estudo é a questão da consolidação da democracia. Sabe-se que o sistema democrático guarda conexão e dependência com a relação dada entre a Defensoria Pública, seus membros e a sociedade. Isso ocorre porque sem a participação da população, não há como alcançar a existência e a consagração dos direitos fundamentais ${ }^{192}$. Os meios de comunicação mais utilizados por parte da sociedade mais vulnerável encontram-se centralizados no atendimento presencial na própria Defensoria Pública e até mesmo por meio das Ouvidorias (o que é também uma forma de controle externo), bem como,

\footnotetext{
188 IV Diagnóstico da Defensoria Pública no Brasil.p. 66-67. Acesso em: 10 mai. 2018.

${ }^{189}$ Ibid., p. 72.

${ }^{190}$ Ibid., p. 72.

${ }^{191}$ Ibid., p. 73.

${ }^{192}$ Ibid., p. 74.
} 
por atendimento telefônico regular e gratuito ${ }^{193}$. Além disso, para que haja uma maior aproximação das pessoas com a Instituição, é preciso analisar a forma que as Defensorias Públicas realizam as suas campanhas e divulgação dos seus serviços jurídicos e extrajurídicos, de forma a demonstrar para a população mais carente o verdadeiro papel da Defensoria Pública, que é o de auxiliar a busca e a efetivação de direitos e prerrogativas, aproximar as pessoas mais necessitadas do mundo jurídico e aprimorar o acesso à justiça, dando oportunidades igualitárias para que as pessoas tenham uma assistência jurídica mais digna e ampla.

Por conta disso, o IV Diagnóstico da Defensoria Pública explicita:

\begin{abstract}
A avaliação das ações de comunicação tende a ser positiva, porém a disponibilização de meios remotos de atendimento (telefone, e-mail, site) e de realização de campanhas de divulgação ou esclarecimento não são práticas amplamente difundidas entre as Defensorias Estaduais, indicando uma capilarização ainda debilitada dos serviços da Defensoria Pública em território nacional. A importância dessas formas de atendimento, divulgação e esclarecimento da população reforça-se à luz dos achados relativos a ainda frágil dispersão territorial das Defensorias Públicas Estaduais e das conhecidas restrições de conhecimento e acesso à informação que a população brasileira possui em relação a assuntos jurídicos. Ampliar o acesso à justiça também pode ser entendido como informar a população-alvo acerca do "direito a ter direitos", garantias civis que vêm sendo tão aguerridamente buscadas pelos Defensores Públicos do Brasil ${ }^{194}$.
\end{abstract}

A partir de todo o relato a respeito das Defensorias Públicas Estaduais, é notório perceber que, apesar dos avanços da Instituição, ainda falta muito para que as disposições legais e constitucionais sejam cumpridas de forma efetiva. Para isso, são necessárias condições materiais objetivas, capazes de viabilizar o seu pleno exercício, bem como o seu acesso à população vulnerável socialmente ${ }^{195}$.

\footnotetext{
${ }^{193}$ IV Diagnóstico da Defensoria Pública no Brasil. p. 79. Acesso em: 10 mai. 2018.

${ }^{194}$ Ibid., p. 82.

195 Ibid., p. 57.
} 


\subsubsection{As Defensorias Públicas Federais e seus maiores desafios}

Assim como foi analisado o cenário da Defensoria Pública Estadual, é preciso também estudar o quadro da Defensoria Pública Federal, tendo em vista que ela também é responsável pela prestação integral e gratuita de assistência jurídica, judicial e extrajudicial ao cidadão hipossuficiente.

A Instituição em âmbito federal é formada, majoritariamente, por homens, que representam $67,6 \%$ do total. Esse percentual é distinto se comparado com os das Defensorias Estaduais, em que a equidade do sexo era maior. Portanto, pode-se dizer que, "a procura por um melhor equilíbrio nessa proporcionalidade de gênero é um desafio que se encaixa com os compromissos da instituição"196. No que tange à faixa etária, a média de idade dos defensores públicos federais é de 37 anos, o que revela que a Instituição é composta por um caráter jovem, assim como ocorre com as Defensorias Públicas Estaduais. Isso chama a atenção, pois questiona-se se o fato da Defensoria Pública ser uma instituição nova corrobora para a entrada de pessoas mais jovens nos quadros da carreira. Em relação à cor ou raça, a maior parte dos servidores declarou-se como branca, representando $73,7 \%{ }^{197}$.

Dessa forma, pode-se dizer:

Essas constatações são de especial relevo para a instituição. As Defensorias Públicas foram criadas para exercer papeis cruciais no âmbito do Sistema de Justiça e da sociedade como um todo, tais como redução das desigualdades sociais. Para que esses objetivos sejam efetivamente alcançados, seria oportuno que a própria instituição refletisse acerca da criação de critérios e de medidas que possam equalizar essas desigualdades internas, que são fruto das desigualdades sociais maiores, as quais a instituição tem por objetivo reduzir ${ }^{198}$.

Assim como foi abordada qual seria a maior motivação dos defensores públicos estaduais, com relação aos defensores públicos federais o interesse pelo trabalho social tem muita força na hora de seguir e escolher

\footnotetext{
${ }^{196}$ IV Diagnóstico da Defensoria Pública no Brasil. p. 84. Acesso em: 10 mai. 2018.

${ }^{197}$ Ibid., p. 85.

${ }^{198}$ Ibid., p. 85.
} 
a carreira. Esse aspecto revela a importância da vocação relacionada ao trabalho do defensor público federal, o de prestar assistência jurídica às pessoas em situações de vulnerabilidade e garantir a elas o acesso aos seus direitos e à Justiça. Além disso, a estabilidade do serviço público e a remuneração são fatores que também influenciam os servidores em sua opção ${ }^{199}$. Por conta do aspecto social intrinsecamente ligado à profissão, a maior parte dos defensores públicos acredita que a afinidade para trabalhar com comunidades carentes é de grande importância para a sua atuação, além do comprometimento com temas sociais ${ }^{200}$.

Do ponto de vista da autonomia conferida à Instituição, 91,8\% dos defensores considera ser muito importante a independência funcional para o exercício da carreira ${ }^{201}$. Por conta disso, o IV Diagnóstico da Defensoria Pública no Brasil dispõe:

O contraste entre a importância atribuída a esse fator e a percepção dos próprios defensores públicos federais quanto à baixa autonomia institucional a qual a DPU dispõe revela um quadro crítico para a instituição, podendo gerar situações de maior frustação e insatisfação com o trabalho ${ }^{202}$.

Sabe-se que a autonomia dos defensores públicos federais veio apenas em 2013, com a aprovação da Emenda Constitucional $\mathrm{n}^{\mathbf{0}}$ 74, assegurando autonomia funcional, administrativa e financeira. Sobre o orçamento da Defensoria Pública da União, cabe relatar aqui que, em 2014, a Instituição elaborou uma proposta legislativa orçamentária, entretanto, o Poder Executivo Federal impediu que esta fosse levada a frente e se tornasse um projeto de lei. Além disso, há um baixo percentual do Fundo Próprio da DPU, somado à inexistência de outras fontes de repasse, o que prejudica profundamente a Instituição, pois é preciso um fortalecimento

\footnotetext{
${ }^{199}$ IV Diagnóstico da Defensoria Pública no Brasil.p. 86. Acesso em: 10 mai. 2018.

${ }^{200}$ Ibid., p. 87.

${ }^{201}$ Ibid., p. 87.

202 Ibid., p. 87.
} 
deste Fundo para trazer melhorias no alcance da tão estimada autonomia ${ }^{203}$. Vale dizer ainda que:

Um dos indicadores do grau de autonomia da Defensoria Pública é o respeito, por parte do Poder Executivo, da obrigatoriedade de repassar as cotas mensais do orçamento destinado à instituição, também chamadas de duodécimos ${ }^{204}$.

A respeito dos gastos da Defensoria Pública da União, pode-se dizer que as despesas estão centralizadas com o pagamento do pessoal e encargos sociais, itens de custeio, convênios para prestação de atividades-fim, eventuais despesas de terceirização de atividades jurídicas realizadas no orçamento da instituição e itens de investimento ${ }^{205}$.

Em relação à autonomia funcional, 92,2\% dos defensores federais disseram que se sentem muito ou totalmente autônomos para exercerem suas atividades profissionais. Consta citar que a maior parte deles acredita ser livre para atuar em casos nos quais o assistido solicita assistência jurídica contra a União ${ }^{206}$. Entretanto, há para eles uma menor autonomia institucional e orçamentária por parte da DPU, sendo que 94,6\% dos defensores federais afirmaram que a unidade em que trabalham possui pouca ou nenhuma autonomia para gerir seus próprios recursos, apontando o Governo Federal como o órgão que mais prejudica a autonomia ${ }^{207}$.

Sobre o trabalho das Defensorias Públicas Federais, somente 13,3\% dos defensores concordaram totalmente que a unidade da DPU em que trabalham tem conseguido cumprir de forma satisfatória com o seu objetivo central. Em relação à atuação dos próprios servidores, 63,5\% acreditam que os profissionais estão preparados para exercerem suas incumbências ${ }^{208}$.

Ademais, é preciso citar também a problemática envolvendo o próprio Poder Judiciário, pois a relação entre os órgãos do Sistema de

\footnotetext{
${ }^{203}$ IV Diagnóstico da Defensoria Pública no Brasil.p. 93-94. Acesso em: 10 mai. 2018.

${ }^{204}$ Ibid., p. 94.

205 Ibid., p. 95.

206 Ibid., p. 97.

${ }^{207}$ Ibid., p. 97-99.

208 Ibid., p. 89.
} 
Justiça foi considerada pelos defensores públicos como um dos grandes empecilhos à atuação deste poder. Assim como o excesso de formalismo, baixos níveis salariais e a má qualidade e tecnicismo do ensino jurídico ${ }^{209}$.

Um dos pontos mais significativos do presente estudo encontra respaldo na quantidade de Defensorias Públicas da União institucionalizadas no Brasil em obediência à Emenda Constitucional de $\mathbf{n}^{\mathbf{o}}$ 80. O IV Diagnóstico da Defensoria Pública no Brasil revelou que em 61 municípios brasileiros há a presença de sedes da DPU, que contam com a atuação de 548 defensores públicos federais. Cerca de 95,8\% dos defensores públicos acreditam que falta muito para que a União cumpra a meta estabelecida no texto constitucional ${ }^{210}$. E isso é extremamente preocupante, pois:

A insuficiência de defensores públicos e a existência de unidades jurisdicionais não atendidas pela DPU impõe restrições e assevera as desigualdades relativas ao acesso à justiça em regiões do país, fragilizando o trabalho realizado pela instituição ${ }^{211}$.

O IV Diagnóstico da Defensoria Pública tratou de elucidar também a quantidade de defensores públicos existentes no ano de 2014. Haviam 550 defensores públicos federais ativos. Contudo, seriam necessários 1.281 para atender à demanda nacional. Por conta disso, há um déficit de 731 defensores no país ${ }^{212}$. Ademais, o número de servidores administrativos também se demonstra insuficiente, assim como o número de profissionais de outras áreas de extrema relevância para a atuação da Instituição, como, por exemplo, os profissionais de psicologia e de serviço social. "Há, ainda, dificuldades na prestação de serviços gerais internos nas unidades, conforme apontado por 79,3\% dos defensores" ${ }^{213}$. Entre essas dificuldades, é possível encontrar "a má qualidade da prestação, a não cobertura de

\footnotetext{
${ }^{209}$ IV Diagnóstico da Defensoria Pública no Brasil.p. 86. Acesso em: 10 mai. 2018.

210 Ibid., p. 107.

${ }^{211}$ Ibid., p. 107.

212 Ibid., p. 100-101.

213 Ibid., p. 102.
} 
determinados serviços e a dificuldade de dialogar com a prestadora contratada" ${ }^{14}$. Ademais, $91,8 \%$ dos defensores públicos federais se sentem sobrecarregados, evidenciando a mesma necessidade que as Defensorias Estaduais possuem, a da interdisciplinaridade ${ }^{215}$.

Assim como os defensores públicos estaduais precisam de capacitação, os defensores federais também. Tudo isso em prol de uma prestação de serviços jurisdicionais mais eficientes e eficazes. Entretanto, nem todos os profissionais parecem conhecer de tais oportunidades de aperfeiçoamento conferidas pela própria Instituição. O IV Diagnóstico da Defensoria Pública explicita que pouco menos de um terço dos defensores públicos federais participaram de alguma capacitação, curso de especialização ou pós-graduação organizados ou até mesmo custeados pela própria Instituição $0^{216}$.

A comunicação interna da Defensoria Pública também é de extrema relevância. Os próprios defensores públicos consideram como muito importante a troca de ideias, experiências e informações com outros profissionais da carreira. Entretanto, 49,6\% disseram que não existe, nas unidades da Defensoria Pública da União em que atuam, espaço para essas trocas, o que prejudica o mecanismo de fortalecimento dos laços institucionais e a disseminação de práticas inovadoras de atuação $0^{217}$.

Foi discutida a questão da acessibilidade das Defensorias Públicas Estaduais, portanto, é necessário pensar também na garantia deste acesso físico para as Defensorias Públicas da União. 17\% dos defensores trabalham em unidades que não podem ser facilmente acessadas para os que dependem do transporte público e 30,6\% estão em locais que não são

\footnotetext{
${ }^{214}$ IV Diagnóstico da Defensoria Pública no Brasil.p. 102. Acesso em: 10 mai. 2018.

${ }^{215}$ Ibid., p. 103.

${ }^{216}$ Ibid., p. 106.

${ }^{217}$ Ibid., p. 106.
} 
adequados para atender pessoas com algum tipo de restrição ou deficiência ${ }^{218}$.

Outrossim, não restam dúvidas de que a qualidade do local de trabalho depende também do seu próprio material e instrumentos. É preciso contar com computadores, telefones, fax, impressoras e estrutura de rede e de acesso à internet. Ou seja, é necessária uma infraestrutura capaz de atender as demandas que são grandes e usuais no dia-a-dia.

O atendimento da Defensoria Pública também precisa ser analisado e estudado, tendo em vista, que quase metade dos defensores afirma inexistir na Instituição um processo de triagem com análise prévia dos casos e orientação dos caminhos que devem ser seguidos, o que atrasa o andamento da assistência jurídica e de todo o serviço. O IV Diagnóstico explicita que se deve uniformizar o fluxo de trabalho da DPU, de forma a aumentar a transparência desses atendimentos ${ }^{219}$. Ainda sobre esta temática, o número de convênios estabelecidos por meio das Defensorias Públicas da União é muito baixo, apenas 9\% dos defensores públicos federais atuam em unidades que os mantêm com outras instituições ${ }^{220}$.

Essa constatação, remete necessariamente à necessidade de se trabalhar para o envolvimento das Defensorias Públicas com os demais atores do Sistema de Justiça por meio da formação de uma rede que viabilize uma solidariedade social com os princípios e objetivos da instituição $0^{221}$.

Assim como as Defensorias Públicas dos Estados, a da União tem se engajado na prestação de assistência jurídica por meios extrajudiciais. 89,8\% dos defensores afirmaram que a unidade da DPU em que atuam realiza esse tipo de exercício, o que é de extrema importância e propicia, muitas vezes, aos mais vulneráveis um acesso à justiça de maneira mais célere 222 .

\footnotetext{
${ }^{218}$ IV Diagnóstico da Defensoria Pública no Brasil. p. 109. Acesso em: 10 mai. 2018.

219 Ibid., p. 112.

${ }^{220}$ Ibid., p. 113.

${ }^{221}$ Ibid., p. 113.

222 Ibid., p. 1114.
} 
Outra preocupação apresentada está pautada no fato de que apenas $13,1 \%$ dos defensores federais dizem estar atuando em unidades da DPU que mantém parcerias com outras instituições para encaminhamento de casos que não são cobertos pela Defensoria Públicaa ${ }^{223}$. O IV Diagnóstico revela:

\begin{abstract}
A baixa adesão às parcerias formais ilustra um cenário de desarticulação da instituição. Para atenderem ao objetivo a que se prestam cumprir, é importante que as Defensorias Públicas se posicionem como articuladoras do sistema de justiça em favor dos necessitados. Essa atuação deveria envolver o relacionamento tanto com os órgãos e entidades do poder público, quanto com organizações não governamentais de interesse público e com a própria sociedade civil em geral ${ }^{224}$.
\end{abstract}

Como falado muitas vezes, a Defensoria Pública é uma Instituição que representa o regime democrático instituído pela Constituição Federal de 1988. Levando isso em consideração, é preciso pensar na gestão de cada uma delas de forma a preconizar a democracia, tanto internamente, por meio do Conselho Superior, quanto externamente, por meio da própria sociedade civil. Além disso, a comunicação da Defensoria com a população também precisa ser levada em conta. A principal forma de contato é feita presencialmente, mas também por meio de chamadas telefônicas e por email. Além disso, há a figura da Ouvidoria, sendo esta disponível em apenas $21,8 \%$ das unidades, o que demonstra uma discrepância em relação às Defensorias Públicas Estaduais, que contam com 63,9\%. Por outro lado, a utilização do e-mail é muito mais citada pelos defensores federais do que estaduais ${ }^{225}$. Segundo o IV Diagnóstico da Defensoria Pública: "Tanto os meios de comunicação disponibilizados, quanto as campanhas de divulgação dos serviços da Defensoria Pública da União são nada ou pouco adequadas" ${ }^{226}$.

\footnotetext{
${ }^{223}$ IV Diagnóstico da Defensoria Pública no Brasil. p. 114-115. Acesso em: 10 mai. 2018.

${ }^{224}$ Ibid., p. 115.

${ }^{225}$ Ibid., p. 118.

${ }^{226}$ Ibid., p. 119.
} 
Com base em todas as informações descritas acima sobre as Defensorias Públicas Federais, é possível dizer que elas se desenvolveram ao longo dos anos. Contudo, algumas dificuldades continuaram persistindo no quadro atual da Instituição, comprometendo o trabalho dos defensores públicos federais e prejudicando o exercício da assistência jurídica de forma integral e gratuita. Por conta disso, é imprescindível pensar em possíveis respostas, recursos e soluções para abarcar e superar tais obstáculos.

\subsection{Possíveis Soluções no Cenário das Defensorias Públicas}

A partir da leitura do IV Diagnóstico, de obras doutrinárias de relevo e da própria experiência na Defensoria Pública por meio de estágio, é preciso citar aqui algumas medidas que estão em pauta e sendo muito bem aceitas pelos próprios defensores públicos.

Primeiramente, pode-se dizer que a atuação na tutela dos direitos coletivos é um assunto muito abordado na atualidade, já que a Defensoria Pública possui legitimidade para atuar em causas que contenham direitos difusos, coletivos em sentido estrito e individuais homogêneos. Como visto anteriormente, a Instituição pode, de forma coletiva, ingressar com uma ação civil pública e até mesmo com um mandado de segurança. Isso representa um grande avanço para a própria coletividade, que poderá ser representada pela Defensoria Pública e, consequentemente, obter os seus devidos direitos. Dessa forma, como uma das ideias inovadoras, a tutela coletiva precisa ser mais abordada e consagrada pela Instituição, visto que é uma forma de diminuir inúmeras demandas, ao mesmo tempo que torna o acesso à justiça mais célere e evita a contradição de decisões judiciais e até mesmo extrajudiciais.

Falando sobre decisões extrajudiciais, é preciso também preconizar a função extrajurídica da Defensoria Pública, lembrando sempre que a sua atuação está pautada na assistência jurídica integral, que alcança não só o Poder Judiciário, como também outras formas de solução de conflitos. Uma 
maneira de desencadear esse regime extrajudicial seria por meio da execução de conciliações no próprio âmbito da Defensoria Pública. Para isso, seria preciso que o número de servidores e estagiários atuantes fosse maior e extremamente capacitado para realizar esses acordos entre os assistidos. Por meio dessa atividade, o número de processos judiciais tornar-se-ia menor e a Defensoria Pública estaria realizando a composição amigável de conflitos e ao mesmo tempo seguindo os ditames constitucionais e legais, já que possui esse dever.

Ademais, até mesmo como forma de estímulo para os defensores públicos, seria muito importante que houvesse equiparação da remuneração às carreiras do Ministério Público. Isso porque é necessário igualar o tratamento dispendido às Instituições, até mesmo como uma forma de valorização da carreira e do profissional, já que ambas as Instituições exercem funções essenciais à justiça, não havendo diferenças entre os seus valores na Constituição Federal.

Outra possibilidade de mudança está voltada para as práticas preventivas e educativas. Sabe-se que muitas das pessoas que vão até as Defensorias Públicas não estão cientes dos direitos que possuem, pois falta um bom fornecimento de informações, o que influencia demasiadamente o serviço público. Deve-se levar em consideração que a maior parte dos que procuram a Defensoria não tem ideia do procedimento adequado e da área de atuação em relação à competência jurisdicional daquela respectiva unidade da Instituição. Por conta disso, a Defensoria Pública poderia viabilizar por meio de campanhas um ensino jurídico para parte dessa população mais vulnerável, com o intuito de educar e disponibilizar meios e recursos para os mais variados conflitos vivenciados pela sociedade.

A criação de Ouvidorias externas também é outra medida que poderia ser eficaz por ser uma boa opção de controle. Na verdade, uma das finalidades deste órgão institucional é a observância das práticas e das políticas públicas desenvolvidas pela Defensoria Pública por meio da 
própria sociedade civil, preconizando, dessa forma, um contato direto com as pessoas que dependem da Instituição.

É urgente e necessário que ocorra obediência prática à Constituição na redação dada pela Emenda Constitucional de nº 80 de 2014. Pois, como falado anteriormente, a Emenda acrescentou o art. 98 ao Ato das Disposições Constitucionais Transitórias, deixando claro que, até 2022, a União, os Estados e o Distrito Federal deverão contar com defensores públicos em todas as unidades jurisdicionais. Esse comando constitucional precisa ser seguido, pois ainda hoje existem locais em que não há a presença de uma Defensoria Pública ativa, o que dificulta e impossibilita o real e amplo acesso à justiça das pessoas mais vulneráveis. Pois questionase: o que acontece com aqueles que não estão e não podem ser tutelados por uma dessas Instituições? Muitos responderão que existem convênios capazes de abarcar essa situação. Contudo, foi analisado acima que o número existente de convênios é muito inferior ao almejado, o que demonstra uma forte necessidade de maiores negociações com outras instituições, tudo em prol dessas pessoas que não podem e não possuem condições financeiras para contratar um advogado particular. Da mesma forma, a ampliação do quadro de defensores, servidores e estagiários também é de fundamental relevância, até mesmo por conta da interdisciplinaridade no trabalho que precisa ser imediatamente consagrada, assim como expressa o IV Diagnóstico da Defensoria Pública no Brasil:

\footnotetext{
Enfim, refletir acerca de uma melhora de estrutura da DPU implica, impreterivelmente, assumir o caráter interdisciplinar do Direito e valorizar a presença de profissionais de apoio, bem como daqueles que possam substituir as demandas dos Defensores que, por motivo de férias, doença ou força maior, tenham que se afastar temporariamente de seus ofícios. Essa medida, de certo, colaborará para aliviar a impressão real dos Defensores acerca do excesso de demandas, gerará maior efetividade para o trabalho e contribuirá para que casos mais complexos sejam acompanhados pela instituição de maneira mais eficaz ${ }^{227}$.
}

${ }^{227}$ IV Diagnóstico da Defensoria Pública no Brasil. p. 104. Acesso em: 10 mai. 2018. 
Ademais, é possível vislumbrar a dificuldade do acesso da população à própria Defensoria Pública, ou seja, o excesso de pessoas que esperam nos núcleos de atendimento é frequentemente alarmante, visto que a quantidade de defensores públicos, servidores administrativos e de apoio é desproporcional. Vale dizer que, na maior parte dos casos, o sujeito que procura assessoramento da instituição perde o seu dia de trabalho e produtividade esperando para ser atendido.

Ainda sobre a questão da implementação das Defensorias Públicas, como visto acima, “é imprescindível que as Defensorias Públicas unam forças entre si e com toda a sociedade para reivindicar a concretização dessa conquista constitucional" 228 . Além da luta pela existência de novas unidades e pela maior quantidade de defensores públicos, é preciso garantir que o público alvo tenha reais condições físicas de acesso a esses locais, ou seja, "sendo sua missão garantir a defesa dos mais necessitados, é imprescindível que esses tenham, de fato, acesso aos serviços prestados pelas Defensorias Públicas" ${ }^{229}$. Portanto, ao serem instituídas, deve-se sempre pensar na sua acessibilidade, localização, se há transporte público no local, bem como atentar para o fato de que existem pessoas com deficiências que necessitam de um espaço com capacidade para atender tais dificuldades de mobilidade. "Qualquer restrição espacial que venha dificultar ou mesmo impedir o acesso da população carente aos serviços de responsabilidade da Defensoria Pública estaria inviabilizando o cumprimento de sua missão" 230 .

Além disso, é preciso observar também a infraestrutura das Defensorias Públicas. Muitas são as unidades em que não existe quantidade suficiente de computadores, fax, telefones e outros materiais capazes de viabilizar e proporcionar um serviço mais rápido e eficaz. Até mesmo a existência de mesas, cadeiras e salas é escassa em algumas dessas

\footnotetext{
${ }^{228}$ IV Diagnóstico da Defensoria Pública no Brasil. p. 65. Acesso em: 10 mai. 2018.

${ }^{229}$ Ibid., p. 66.

${ }^{230}$ Ibid., p. 66.
} 
Instituições, prejudicando a prestação da assistência jurídica. Essa barreira justifica-se, muitas das vezes, por conta da distribuição econômica desequilibrada que é destinada à manutenção da instituição através do duodécimo.

Outro aspecto que precisa ser modificado com agilidade e presteza é o fato das Defensorias Públicas continuarem muito dependentes e subordinadas à estrutura administrativa dos seus respectivos Poderes Executivos, dificultando assim, o funcionamento da instituição. É cediço o entendimento de que essas Instituições possuem autonomia financeira, institucional e funcional, porém é preciso que isso seja uma realidade para que ocorra a redução das dificuldades em nome da boa e eficiente atuação da Defensoria, pois esta característica da Instituição assegura a própria defesa do interesse público. O IV Diagnóstico explicita:

O Defensor Público necessita, por definição, de liberdade e independência profissional, de modo que seja possível atuar com qualidade em casos nos quais as partes demandantes estejam em conflito com a própria União ou os próprios Estados. A instituição, por sua vez, necessita de independência, para garantir que sua administração não fique subordinada a outras organizações. A autonomia financeira representa uma grande conquista, ou objetivo a ser alcançado, uma vez que a maioria dessas instituições ainda repousa sob a tutela da União ou dos Estados, não sendo destinados recursos orçamentários fixos, tal como é feito para o Ministério Público ou para a Magistratura ${ }^{231}$.

Assim, torna-se indispensável que os recursos orçamentários provenientes da União ou dos Estados sejam distribuídos de forma igualitária para as Instituições, de forma a preconizar o princípio da equidade e resguardar a Defensoria Pública, propiciando instrumentos capazes de elevar a prestação do serviço público. Além de ser essencial a revisão da forma de gestão desses recursos, "no intuito de tornar mais eficiente a aplicação e alocação do montante" ${ }^{232}$.

${ }^{231}$ IV Diagnóstico da Defensoria Pública no Brasil. p. 129. Acesso em: 10 mai. 2018.

${ }^{232}$ Ibid., p. 97. 
$\mathrm{O}$ atendimento prestado pelos defensores públicos também precisa ser transformado, no sentido de ser mais humanístico e comunitário. Augusto Tavares Rosa Marcacini revela:

\begin{abstract}
Quanto à maneira de prestar atendimento individual, o necessitado deve ter o mesmo tratamento que seria dispensado a qualquer cliente de um escritório de advocacia: deve ser informado da melhor maneira possível acerca dos detalhes que envolvam o caso. Não basta uma atitude paternalista de dizer-lhe 'eu cuido do seu caso', mas deve o beneficiário ser esclarecido quanto à sua situação jurídica, às suas chances, o que pesa a seu favor e o que pesa contra. $\mathrm{O}$ atendimento deve fazer com que o caso sirva de experiência ao cliente para situações da vida futura, devem ser-lhe esclarecidos, ainda que de uma forma bastante simplificada, o funcionamento da máquina judicial e algumas noções básicas de Direito que o façam compreender o que se passa. Além disso, o atendimento deve procurar vencer a barreira sociocultural que separa o beneficiário do advogado. Palavras simples devem ser usadas, e deve-se procurar conversar com calma, pois a diferença de vocabulário pode levar a alguns malentendidos ${ }^{233}$.
\end{abstract}

Outra sugestão para tornar o acesso à justiça mais amplo e efetivo está centralizada na comunicação interna entre os membros da Defensoria Pública. Esse contato é muito importante para fins de troca de ideias e de informações. "Cabe ressaltar que a cooperação e colaboração esperada entre as Defensorias é no sentido da "capacidade de manutenção de intersubjetividade do conhecimento" ${ }^{234}$. A efetivação de canais de comunicação entre os Defensores possui um importante papel no aperfeiçoamento do trabalho desenvolvido por eles. "A construção desses espaços depende da vontade institucional e deve estar alinhada às próprias necessidades dos Defensores, permitindo que eles se tornem meios eficazes para o trabalho" 235 .

Por fim, o IV Diagnóstico da Defensoria Pública no Brasil apresentou a opinião de um dos defensores entrevistados e esta chama a atenção por revelar os maiores embates da Instituição aqui citados:

\footnotetext{
233. MARCACINI, Augusto Tavares Rosa. Assistência Jurídica, Assistência Judiciária e Justiça Gratuita. Rio de Janeiro: Forense, 1996. p. 71-72 apud ALVES, Cléber Francisco. Justiça para todos! Assistência Gratuita nos Estados Unidos, na França e no Brasil. Rio de Janeiro: Lumen Juris, 2006. p. 329.

${ }^{234}$ IV Diagnóstico da Defensoria Pública no Brasil. p. 57. Acesso em: 10 mai. 2018.

${ }^{235}$ Ibid., p. 107.
} 
A Defensoria Pública brasileira, da União, dos Estados e do DF, precisa ter sua autonomia observada pelos demais órgãos do Estado, com orçamento adequado para fazer frente ao desafio de atender a toda a população carente brasileira ou estrangeira em solo brasileiro, com estrutura adequada de trabalho e quadro de pessoal em quantidade suficiente para a prestação do serviço público de assistência jurídica integral e gratuita. Precisa estar em todos os lugares onde o Judiciário esteja instalado, a fim de cumprir o disposto na Constituição Federal após EC $n^{\circ}$ 80/2014. Precisa, por fim, ter reconhecida e valorizada a atividade desenvolvida por seus membros e servidores, com remuneração isonômica com os membros e servidores do órgão de acusação do Estado. Apenas com a superação desses desafios, haverá o efetivo equilíbrio no Sistema de Justiça brasileiro, disponibilizando-se aos assistidos e vulneráveis uma ampla defesa dentro do devido processo legal justo e isonômico entre as partes envolvidas, priorizando-se a educação em direitos e a busca pela resolução extrajudicial dos conflitos sociais ${ }^{236}$.

Dessa forma, é necessário afirmar que a Defensoria Pública precisa continuar avançando e não retrocedendo. Com o auxílio e a participação da sociedade civil, bem como com o comprometimento dos membros da Instituição e com o empenho das entidades federativas em propagar assistência e igualdade para a população, a Defensoria poderá alcançar um patamar de prestação de serviços muito mais avançado e efetivo, concretizando o acesso à justiça de forma extensa e expressiva e, ao mesmo tempo, assegurando o respeito ao princípio da dignidade da pessoa humana, garantindo o mínimo existencial.

\subsection{Algumas Vozes: considerações acerca da Defensoria Pública e do Acesso à Justiça}

Para a presente monografia, foram feitas algumas perguntas a membros da Defensoria Pública, elaboradas com a intenção de, ouvidas as pessoas que lidam diariamente com a beleza e os obstáculos do Acesso ao Poder Judiciário e à Justiça, concluirmos de forma realista a pesquisa contemplada.

\footnotetext{
${ }^{236}$ IV Diagnóstico da Defensoria Pública no Brasil. p. 125-126. Acesso em: 10 mai. 2018.
} 
- Defensora Pública ACIDÁLIA ISABEL DE SOUZA TYMCHAK

Período de exercício: Desde setembro de 1994.

Núcleo de atuação: $18^{a}$ Vara de Família da Comarca da Capital.

1) Sabe-se que os problemas enfrentados pelos assistidos vão muito além de suas situações econômicas. $\mathrm{Na}$ sua opinião, além da vulnerabilidade financeira, qual é a maior dificuldade dessas pessoas?

Acredito que a maioria dos problemas decorre da vulnerabilidade financeira e do total desaparelhamento do Estado nas áreas de saúde, educação e segurança. As pessoas não têm emprego, saúde e educação. E o pior é que, também, não têm perspectivas. A miséria nessas proporções, atrai a promiscuidade e outras mazelas.

2) O que o (a) motivou quando se inscreveu no concurso da Defensoria Pública? O que o (a) motiva, hoje, em sua atuação?

Servir ao próximo foi e ainda é a minha motivação.

3) A Defensoria Pública é importante no cenário vigente? A Defensoria Pública pode ser considerada um verdadeiro agente do Acesso à Justiça? Como o (a) senhor (a) descreve o papel da Defensoria e o seu papel como membro dessa Instituição?

A Defensoria não só é importante, mas essencial, principalmente no cenário vigente, o qual é desolador! Com o empobrecimento da sociedade e o fechamento dos escritórios modelos de várias universidades falidas, a Defensoria tem sido procurada por muito mais pessoas, as quais não teriam acesso a justiça se não fosse a $D P$.

Descrevo a DP com o texto do artigo 134 da Constituição da República, in verbis: A Defensoria Pública é instituição permanente, essencial à função jurisdicional do Estado, incumbindo-lhe, como expressão e instrumento do regime democrático, fundamentalmente, a orientação jurídica, a promoção dos direitos humanos e a defesa, em todos os graus, judicial e extrajudicial, dos direitos individuais e coletivos, de forma integral e gratuita, aos necessitados, na forma 
do inciso LXXIV do art. $5^{\circ}$ desta Constituição Federal. (Redação dada pela Emenda Constitucional no 80, de 2014).

O meu papel é tornar efetivo o comando constitucional, viabilizando o acesso à justiça aos juridicamente necessitados.

4) Qual é o maior problema, na sua visão, enfrentado pela Instituição nos dias atuais?

Falta de recursos financeiros.

5) A partir do seu ponto de vista, o (a) senhor (a) tem alguma sugestão ou proposta de inovação que torne a Acesso à Justiça mais efetivo?

A Defensoria Pública tem excelentes profissionais, os quais estão equipados intelectualmente para realizar um trabalho cada vez maior e melhor. Entretanto, as ideias e projetos esbarram sempre no reduzido orçamento. Infelizmente, os políticos brasileiros não estão preocupados com o bem-estar da população, em especial da população carente.

- Defensor Público JOÃO HENRIQUE VIANNA RODRIGUES

Período de exercício: posse em outubro de 1994.

Núcleo de atuação: titular e em exercício no Núcleo de Primeiro Atendimento da Regional da Barra da Tijuca (desde janeiro de 2015).

1) Sabe-se que os problemas enfrentados pelos assistidos vão muito além de suas situações econômicas. $\mathrm{Na}$ sua opinião, além da vulnerabilidade financeira, qual é a maior dificuldade dessas pessoas?

A maior dificuldade das pessoas é a falta de conhecimento sobre os seus direitos. Esta falta de conhecimento tem origem na falta de educação básica. São anos e anos de descaso com a educação. Há falta de investimentos na Educação como um todo (faltam escolas, vagas e professores). As escolas e a formação de professores deveriam ser priorizadas. 
2) O que o (a) motivou quando se inscreveu no concurso da Defensoria Pública? O que o (a) motiva, hoje, em sua atuação?

A principal motivação que me levou a me inscrever no concurso para ingresso na carreira da Defensoria Pública é garantir às pessoas juridicamente hipossuficientes e vulneráveis o acesso à Justiça, mas, principalmente, a informação sobre direitos e deveres, seja orientando, propondo ações, defendendo em Juízo ou fora dele, dentre outras.

3) A Defensoria Pública é importante no cenário vigente? A Defensoria Pública pode ser considerada um verdadeiro agente do Acesso à Justiça? Como o (a) senhor (a) descreve o papel da Defensoria e o seu papel como membro dessa Instituição?

Os direitos sociais cada vez mais são exigidos pelos cidadãos. Mas para conquistar estes direitos é preciso conhecê-los. A Defensoria Pública tem a função de garantir a cidadania aos hipossuficientes $e$ vulneráveis. Muitas vezes estas pessoas até sabem de seus direitos, mas não têm meios, ou desconhecem, como exercê-los. A Defensoria Pública tem o papel constitucional de levar a cidadania aos cidadãos, garantindo a dignidade da pessoa humana.

4) Qual é o maior problema, na sua visão, enfrentado pela Instituição nos dias atuais?

Para que a Defensoria Pública cumpra a sua função constitucional há necessidade de maior investimento em infraestrutura e pessoal. Há necessidade de investimentos em equipamentos modernos (locais de atendimento, computadores e scanners modernos), pessoal (abertura de concurso público para peritos médicos, dentistas, engenheiros, contadores, tradutores, serviços de apoio, dentre outros).

5) A partir do seu ponto de vista, o (a) senhor (a) tem alguma sugestão ou proposta de inovação que torne o Acesso à Justiça mais efetivo?

O Acesso à Justiça se tornará mais efetivo com investimentos nas Defensorias Públicas de todos os Estados da Federação e da Defensoria Pública da União. Reporto-me à questão anterior: há necessidade de investimentos em infraestrutura, abertura de 
concurso público para peritos técnicos, pessoal de apoio e defensores públicos.

\section{- Defensor Público CLEBER FRANCISCO ALVES}

Período de exercício: Desde maio de 1994.

Núcleo de atuação: Defensoria Pública da $4^{\text {a }}$ Vara Cível de Petrópolis (especializada em matéria Fazendária).

1) Sabe-se que os problemas enfrentados pelos assistidos vão muito além de suas situações econômicas. Na sua opinião, além da vulnerabilidade financeira, qual é a maior dificuldade dessas pessoas?

Creio que o desconhecimento acerca dos direitos e sobre o exercício pleno da cidadania, que se agrava ainda mais devido ao baixo grau de escolarização de grande parte da população brasileira, são fatores que dificultam o acesso à justiça e aos direitos.

2) O que o (a) motivou quando se inscreveu no concurso da Defensoria Pública? O que o (a) motiva, hoje, em sua atuação?

Para ser bem sincero, no momento quando fiz minha inscrição para o concurso da Defensoria Pública eu não tinha propriamente escolhido exclusivamente essa carreira: tinha pouco tempo de formado e estava tentando aprovação também em outros concursos; acabei sendo aprovado no primeiro e único concurso que prestei para a carreira da Defensoria Pública e me identifiquei plenamente com a função e missão institucional, na qual tenho me realizado pessoal e profissionalmente. A grande motivação é poder lutar pela realização do Direito e da Justiça, em prol de concidadãos que muito dificilmente teriam como ter acesso a serviços jurídicos, sobretudo por não dispor de recursos para custear as despesas com advogado. Mas também a possibilidade de atuar de modo proativo, estrategicamente, para promover a dignidade e os direitos humanos em geral.

3) A Defensoria Pública é importante no cenário vigente? A Defensoria Pública pode ser considerada um verdadeiro agente do Acesso à 
Justiça? Como o (a) senhor (a) descreve o papel da Defensoria e o seu papel como membro dessa Instituição?

Com toda certeza a Defensoria Pública é não só importante, mas, tal como literalmente estabelece a Constituição Federal, essencial, indispensável. Definitivamente, eu concordo com a assertiva que o Defensor Público é agente de acesso à justiça. Acho que já respondi à terceira indagação, na questão anterior, creio que nosso papel de Defensor Público não pode ser apenas o de um "burocrata" que atua mecanicamente, postulando direitos e apresentando defesas, desempenhando apenas uma atividade técnica. Precisamos ser agentes de promoção de direitos humanos, e atuar proativamente, criativamente, e - sobretudo - preventivamente, por meio de medidas extrajudiciais diversas, e com uma atuação de caráter estratégico para alcançar maior igualdade no acesso aos direitos e no pleno exercício da cidadania.

4) Qual é o maior problema, na sua visão, enfrentado pela Instituição nos dias atuais?

A Defensoria Pública ainda não tem recebido um tratamento de cunho orçamentário-financeiro suficiente para desempenhar sua missão; em muitas Comarcas a Defensoria ainda não foi implantada, e-diante do quadro adverso vivido pelo nosso país -é lamentável perceber que não se vislumbra a curto prazo um horizonte de avanços significativos nesse campo.

5) A partir do seu ponto de vista, o (a) senhor (a) tem alguma sugestão ou proposta de inovação que torne o Acesso à Justiça mais efetivo?

No momento, não me ocorre nenhuma sugestão específica. $O$ aparelhamento e efetiva implantação da Defensoria Pública em todas as Comarcas, e perante todos os órgãos do Judiciário é uma meta determinada expressamente pela Emenda Constitucional 80, mas que ainda está longe de ser efetivado.

\section{- Defensor Público ROGÉRIO RABE}

Período de exercício: Desde outubro de 1990. 
Núcleo de atuação: Órgão da Defensoria junto ao Órgão Especial, Corregedoria da Justiça e Conselho da Magistratura.

1) Sabe-se que os problemas enfrentados pelos assistidos vão muito além de suas situações econômicas. $\mathrm{Na}$ sua opinião, além da vulnerabilidade financeira, qual é a maior dificuldade dessas pessoas?

As pessoas que procuram a Defensoria são carentes de tudo, principalmente instrução mínima de cidadania. Os sentimentos de vulnerabilidade e humilhação são patentes. Muitas vezes, apenas uma atenção e a explicação do que está ocorrendo, já restabelece alguma autoconfiança, apaziguando o espírito. A maioria dos assistidos são completamente cegos e inconformados com relação à sua situação jurídica ou a de parentes próximos. Assim, a maior dificuldade é ausência de instrução básica quanto às Instituições $e$ suas funções, que os leva, muitas vezes, ao verdadeiro desespero.

2) O que o (a) motivou quando se inscreveu no concurso da Defensoria Pública? O que o (a) motiva, hoje, em sua atuação?

O que me motivou, com certeza, foi a carreira, sua estabilidade e a possibilidade de levar uma vida tranquila, mesmo sabendo que não iria enriquecer. Posteriormente, após atuar em diversas comarca e ter contato com pessoas dos mais diversos tipos e com os mais diversos problemas, realmente me apaixonei pela Instituição. Nenhum ensinamento adquirido no banco universitário, em seminários ou nas diversas especializações, com os mais renomados mestres, sequer chegou aos pés daquele adquirido de uma mãe, que se sacrifica para livrar seu filho, mesmo sabendo que ele é culpado pelo delito. Infinitas situações vão moldando o caráter $e$ contextualizando toda ciência do Direito. Exatamente este sentimento me move e aos meus colegas. Cada vitória deve ser muito comemorada, como fez David ao derrotar o poderoso Golias. Nós somos, como costumo dizer, "médicos de almas", pois com a nossa atuação, apaziguamos os maus sentimos e aliviamos a dor d'alma. Enfim, a paixão é o que me motiva.

3) A Defensoria Pública é importante no cenário vigente? A Defensoria Pública pode ser considerada um verdadeiro agente do Acesso à Justiça? Como o (a) senhor (a) descreve o papel da Defensoria e o seu papel como membro dessa Instituição? 
A Defensoria é a principal forma de acesso à Justiça, encastelada e inatingível para o homem médio. Sua função não se limita à atuação judicial. O Defensor é um Agente Político do Estado e, como tal, deve agir em todas as áreas que possam beneficiar a sociedade. Assim, a realização de campanhas de esclarecimento e atividades judiciais para minorar o sofrimento dos apenados, para esclarecer a igualdade racial, para se dar valor às minorias e parcelas mais vulneráveis da sociedade (como as mulheres, idosos e menores) são atividades que diferem o Defensor Público de um advogado, que deve ser comprometido unicamente com seu cliente. Em um país como o nosso, com tantas necessidades básicas e de instrução, revelando uma desigualdade social abissal, a Defensoria é o mais importante vetor de desenvolvimento humano. Desde o meu ingresso na Instituição já exerci diversos cargos na Administração, como Coordenador Geral de Direitos Humanos, Assessor Criminal, Membro da Banca Examinadora para Ingresso na Carreira por quatro vezes consecutivas. Hoje exerço o cargo de Defensor de Classe Especial, junto ao Segundo Grau. Enfim, continuo a participar de minha Instituição de forma ativa e contribuindo para seu engrandecimento.

4) Qual é o maior problema, na sua visão, enfrentado pela Instituição nos dias atuais?

Realmente houve um maciço aumento da quantidade de pessoas que estão se socorrendo da Instituição, nesse momento de crise econômica. Dessa forma, os projetos para a melhoria da sociedade, através de conscientização de Direitos, passam por momento de dificuldade. $O$ reconhecimento da igualdade institucional entre os membros das demais carreiras do Judiciário, como a Magistratura e o Ministério Público, ainda não foi alcançado. Detecto ainda a tendência de diminuição de Direitos, de forma institucionalizada pelo Estado Brasileiro, vulnerabilizando, ainda mais, as camadas empobrecidas da sociedade. Enfim, a Defensoria Pública briga, em seu âmago, por uma sociedade mais humanizada e progressiva, aberta e igualitária, sem tantas desigualdades. Nos dias atuais, estamos presenciando justamente o contrário ocorrer. São esses os maiores problemas enfrentados pela Instituição.

5) A partir do seu ponto de vista, o (a) senhor (a) tem alguma sugestão ou proposta de inovação que torne o Acesso à Justiça mais efetivo?

Minha proposta sempre foi a valorização da figura Política do Defensor Público. Por muitas vezes participei de programas de 
rádio e de televisão, tentando esclarecer os direitos das pessoas. Fazer com que as pessoas tenham conhecimento, de forma coletiva e ampla, de seus direitos e deveres, é projetar toda a sociedade a um patamar distante da barbárie. Logo, ações coletivas, seja de cunho social ou judicial, devem ser priorizadas.

\section{- Defensor Público ANDRÉ DA SILVA ORDACGY}

Período de exercício: Desde 10 de setembro de 2002

Núcleo de atuação: Núcleo da Defensoria Pública da União - DPU no Rio de Janeiro (capital).

1) Sabe-se que os problemas enfrentados pelos assistidos vão muito além de suas situações econômicas. $\mathrm{Na}$ sua opinião, além da vulnerabilidade financeira, qual é a maior dificuldade dessas pessoas?

Sem dúvida nenhuma a maior dificuldade hoje do público alvo da Defensoria Pública, desconsiderando a situação econômica, talvez seja a ausência de conscientização dos próprios direitos, que pode ser traduzida na falta de informação sobre os seus direitos. $O$ Assistido sequer procura os mecanismos e instituições de acesso à justiça porque desconhece os seus direitos. Obviamente que não me refiro aos direitos mais midiatizados, como por exemplo o dano moral (por não ter recebido uma geladeira ou por ter o nome negativado indevidamente). Refiro-me, sim, a direitos que por vezes podem ser até elementares, mas que não são culturais na consciência da população carente, como por exemplo o direito à educação e ao lazer. Acham, por exemplo, que não ter aula por carência de professor na rede pública é o normal, ou então que a praça pública ter os seus equipamentos/brinquedos permanentes quebrados e sem manutenção é uma situação normal também, exatamente por ser "público", como se o Estado estivesse fazendo um favor à população.

2) $\mathrm{O}$ que o (a) motivou quando se inscreveu no concurso da Defensoria Pública? O que o (a) motiva, hoje, em sua atuação?

Sou um apaixonado por Defensoria desde que ingressei na faculdade de direito. Logo no segundo período iniciei estágio "voluntário" na Defensoria Estadual, e quando atingi o sétimo 
período da faculdade pude iniciar o estágio oficial na Defensoria. Depois fiz vários concursos públicos para defensor público, até que passei para Defensor Público Federal na DPU (ingresso em 2002). Posso dizer que amo o que faço, amo ajudar aos necessitados $e$ vulneráveis, é o que me motiva desde que ingressei na carreira até hoje. Não pretendo mudar de carreira jurídica, não me importando se juizes e promotores auferem subsídios (salários) e gratificações melhores que os defensores públicos.

3) A Defensoria Pública é importante no cenário vigente? A Defensoria Pública pode ser considerada um verdadeiro agente do Acesso à Justiça? Como o (a) senhor (a) descreve o papel da Defensoria e o seu papel como membro dessa Instituição?

A Defensoria Pública não só é importante, como é imprescindivel no cenário vigente, exatamente por ser verdadeiro agente do acesso à justiça. A Defensoria Pública possibilita sejam ultrapassados os óbices diversos, principalmente os econômicos (mas não apenas estes), para que a população carente possa acessar com plenitude dos seus direitos, nas vias extrajudicial e judicial. A Defensoria Pública atualmente tem crescido bastante nos campos da tutela coletiva e da atuação como custus vulnerabilis, importantes campos da concretização do acesso à justiça. Como membro da DPU procuro exercer um papel de agente de transformação da realidade social por meio do viés jurídico-processual. Nos últimos anos tenho participado inclusive de Projetos Itinerantes "Eu tenho Direito", promovidos pela Defensoria Federal em cidades do interior que não contam com sede da DPU, justamente para procurar esse acesso à justiça.

4) Qual é o maior problema, na sua visão, enfrentado pela Instituição nos dias atuais?

Sem dúvida alguma o maior problema hoje é o orçamentário. A Defensoria Pública sempre foi o "patinho feio" do sistema judicial. Temos atualmente um Judiciário e um Ministério Público bem estruturados, inclusive no aspecto financeiro-orçamentário, ao passo que a Defensoria Pública nunca conta com um orçamento condizente com as suas necessidades. Isso significa dizer que o Estado valoriza mais a acusação e o julgamento do que o papel da defesa dos direitos. Quando finalmente a Defensoria Pública da União começa uma evolução orçamentária, que poderia significar a sua concreta interiorização nos Estados (vez que hoje a DPU está praticamente restrita às capitais, com algumas exceções), ela acaba 
sendo atingida pela Emenda Constitucional do "teto de gastos", que engessará o seu crescimento por pelo menos dez anos e podendo chegar a vinte anos de paralisia institucional. Ocorre que Judiciário Federal e MPF já estão bem interiorizados, o que revela a crueldade da medida de restrição, sem considerar os aspectos peculiares de cada caso concreto.

5) A partir do seu ponto de vista, o (a) senhor (a) tem alguma sugestão ou proposta de inovação que torne o Acesso à Justiça mais efetivo?

Acho necessário que o Estado invista cada vez mais na conscientização de direitos da população como um todo, inclusive com a disponibilização de mecanismos que possibilitem a concretização de direitos pela via extrajudicial/administrativa. 


\section{CONCLUSÃO}

Em virtude de todos os aspectos apresentados ao longo da monografia, é de fundamental importância, primeiramente, enaltecer o papel da Defensoria Pública na vida das pessoas mais vulneráveis da sociedade, pois sem esta Instituição não haveria a possibilidade de alcançar meios e alternativas eficazes para que o direito ao acesso à justiça fosse concretizado.

Este direito é extremamente relevante no ordenamento jurídico brasileiro, pois é através dele que os hipossuficientes poderão ter a oportunidade de atingir os seus interesses e a suas prerrogativas legal e constitucionalmente previstas. Com isso, é possível afirmar de forma contundente que o acesso à justiça é um direito instrumental, apto a realizar e garantir todos os demais.

Por conta dessa função, é necessário assegurar a eficácia do acesso à justiça. E é por meio da Defensoria Pública que essa incumbência é assumida, sendo uma grande ferramenta para a prestação da assistência jurídica integral e gratuita. Cabe salientar que, este amparo fornecido pela Instituição não conta apenas com o acesso à um procedimento judicial, isto é, não está conectado somente com o ingresso no Poder Judiciário, mas vai muito além disto, possibilitando também auxílio em âmbito extrajudicial, através, por exemplo, da consultoria, do aconselhamento, da informação, da conciliação e da educação jurídica.

Dessa forma, fica claro que o exercício da Instituição não pode ser ignorado pelo Poder Público, tendo em vista que, a Defensoria Pública é responsável por preconizar a democracia, a igualdade, a dignidade da pessoa humana, e, consequentemente, prestigiar o Estado Democrático de Direito. Ou seja, se a Defensoria não obter recursos e condições para o seu bom e adequado funcionamento, todos os princípios consagrados no texto 
constitucional estarão em jogo, prejudicando a população e impedindo o amplo acesso à justiça.

Nesse caso, é necessária uma maior valorização da Instituição e dos seus profissionais, não sendo correto e considerável o tratamento distinto dado pelos entes públicos às Defensorias. Portanto, a Administração Pública tem que prezar pelo bom desempenho da Instituição, pois cumprindo com esta obrigação, automaticamente, estará auxiliando e protegendo a população brasileira. É a partir daí que se inicia a luta por direitos equânimes e por um tratamento isonômico, para que assim, seja possível tratar as pessoas mais frágeis economicamente, socialmente e culturalmente de um modo mais justo, digno e respeitável.

Durante o presente trabalho, todos esses aspectos foram explorados de uma maneira mais densa, com o intuito de compreender o atual cenário da Defensoria Pública na promoção do acesso à justiça, sendo este um elemento da dignidade da pessoa humana e um fator primordial para a consagração do mínimo existencial.

Através de todo o estudo, do IV Diagnóstico da Defensoria Pública e das entrevistas realizadas, fica evidente que a Defensoria ainda tem um longo caminho para percorrer no sentido de romper as barreiras e os obstáculos que impedem o exercício efetivo da assistência jurídica. Sendo assim, é preciso que sejam colocadas em prática as soluções apresentadas no capítulo três, pois elas poderão modificar esse contexto, propiciando e constituindo uma sociedade mais humanitária, plural, solidária e igualitária.

Pode-se dizer então, que as propostas apresentadas têm a finalidade de exaltar e reconhecer a Defensoria Pública como um verdadeiro agente do acesso à justiça, pois é impossível imaginar outra modalidade de serviço público tão única e exclusiva, capacitada, vocacionada e habilitada para defender os interesses da massa mais desprotegida e desamparada do país. 


\section{REFERÊNCIAS BIBLIOGRÁFICAS}

ALVES, Cléber Francisco. Justiça para todos! Assistência Gratuita nos Estados Unidos, na França e no Brasi. Rio de Janeiro: Lumen Juris, 2006. p. $534 \mathrm{p}$.

Apresentação do Estudo Diagnóstico da Defensoria Pública no Brasil. p. 132. Disponível em:

<https://www.anadep.org.br/wtksite/downloads/Diag_defensoria.pdf>.

Acesso em: 10 mai. 2018.

BARBORA MOREIRA, José Carlos. O direito à assistência jurídica In: Revista de Direito da Defensoria Pública do Estado do Rio de Janeiro. Rio de Janeiro, ano 4, nº 5, 1991.

BARCELLOS, Ana Paula de. A Eficácia Jurídica dos Princípios Constitucionais. O princípio da Dignidade da Pessoa Humana. $3^{\mathrm{a}}$ ed. São Paulo: Renovar, 2011. 378 p.

BARCELLOS, Ana Paula. Ponderação, Racionalidade e Atividade Jurisdicional. $1^{\mathrm{a}}$ ed. São Paulo: Renovar, 2005. 334 p.

BASTOS, Celso Ribeiro Bastos. Comentários à Constituição do Brasil. v. 2. São Paulo: Saraiva, 1989. 704 p.

BOBBIO, Norberto. A Era dos Direitos. $1^{\mathrm{a}}$ ed. 12. tir. Rio de Janeiro: Campus, 1992.

A Era dos Direitos. $1^{\mathrm{a}}$ ed. $7^{\mathrm{a}}$ tiragem. Rio de Janeiro: Campus, 2004. 97 p. Disponível em:

<https://direitoufma2010.files.wordpress.com/2010/05/norberto-bobbio-aera-dos-direitos.pdf>. Acesso em: 01 nov. 2017.

BONAVIDES, Paulo. Curso de Direito Constitucional. 29a ed., São Paulo: Malheiros Editores, 2014. 862 p.

BRASIL. Constituição (1988). Disponível em:

<http://www.planalto.gov.br/ccivil_03/constituicao/constituicaocompilado. htm>. Acesso em: 05 nov. 2017. 
BRASIL. Lei Complementar $n^{\circ} 80$ de 12 de Janeiro de 1994. Disponível em:

<http://www.planalto.gov.br/ccivil_03/leis/lcp/lcp80.htm?TSPD_101_R0=a dc66cbca779b8292874b84f566a0764z1F000000000000000020058eb1ffff0 $000000000000000000000000005 a e b 9 b 52006 d f a e 12 d>$. Acesso em: 01 mai. 2018.

BRASIL. Tribunal de Justiça do Estado do Amapá. Disponível em: <http://www.tjap.jus.br/portal/66-tjap/corregedoria/faq/166-qual-e-adiferenca-entre-a-defensoria-publica-da-uniao-e-as-defensorias-publicasestaduais.html>. Acesso em: 05 mai. 2018.

CANOTILHO, José Joaquim Gomes. Direito Constitucional e Teoria da Constituição. $7^{\mathrm{a}}$ ed. Coimbra: Almedina, 2003. 1522 p.

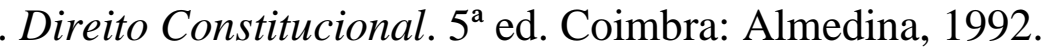

CAPPELLETTI, Mauro; GARTH, Bryan. Acesso à Justiça. NORTHFLEET, Ellen Gracie (Trad.). Porto Alegre: Fabris Editora, 1988. $168 \mathrm{p}$.

Convenção Americana de Direitos Humanos. Pacto de San José da Costa Rica. Disponível em:

$<$ http://www.pge.sp.gov.br/centrodeestudos/bibliotecavirtual/instrumentos/s anjose.htm>. Acesso em: 05 nov. 2017.

CUNHA JÚNIOR, Dirley da. Curso de Direito Constitucional. $8^{\mathrm{a}}$ ed. Salvador: JusPodivm, 2014. 1064 p.

. Curso de Direito Constitucional. Salvador: JusPodivm, 2008.

CUNHA, Sérgio Sérvulo da. Fundamentos de direito constitucional. São Paulo: Saraiva, 2004. 475 p.

Declaração Universal dos Direitos Humanos. Disponível em: <http://www.ohchr.org/EN/UDHR/Documents/UDHR_Translations/por.pd f>. Acesso em: 02 mai. 2018.

DUARTE, Ronnie Preuss. Garantia de Acesso à Justiça: os direitos processuais fundamentais. Coimbra: Coimbra Editora, 2007. 372 p. 
ECONOMIDES, Kim. Lendo as Ondas do "Movimento do Acesso à Justiça": Epistemologia versus Metodologia?. p. 62. Disponível em:

$<$ http://www.comunidadesegura.org.br/files/lendoasondasdomovimentodea cessoajusticaepistemologiaversusmetodologiakimeconomides.pdf $>$. Acesso em: 01 nov. 2017.

ESTEVES, Diogo; ALVES SILVA, Franklyn Roger. Princípios Institucionais da Defensoria Pública. $2^{\mathrm{a}}$ ed. Rio de Janeiro: Forense, 2017. $995 \mathrm{p}$.

FARIA, José Miguel. Direitos Fundamentais e Direitos do Homem. v. 1. $3^{\mathrm{a}}$ ed., Instituto Superior de Ciências Policiais e Segurança Interna, 2001. 336 p.

FENSTERSEIFER, Tiago. Defensoria Pública na Constituição Federal. Rio de Janeiro: Forense, 2017. 259 p.

GARBELLINI, Luis Henrique. Acesso à Justiça. Disponível em: $<$ https://jus.com.br/artigos/19379/acesso-a-justica/1>. Acesso em: 29 out. 2017.

HESSE, Konrad. Grundzugedes Verfassungsrechts der Bundesrepublik Deutschland, 13 ${ }^{\mathrm{a}}$ ed. aum. Heidelberg. 1982 apud BONAVIDES, Paulo. Curso de Direito Constitucional. 29a ed., São Paulo: Malheiros Editores, 2014.

IV Diagnóstico da Defensoria Pública no Brasil. p. 8. Disponível em: $<$ https://www.anadep.org.br/wtksite/downloads/iv-diagnostico-dadefensoria-publica-no-brasil.pdf $>$. Acesso em: 10 mai. 2018.

JUNKES, Sérgio Luiz. Defensoria Pública e o Princípio da Justiça Social, Curitiba: Juruá, 2006, p. 83-84 apud ESTEVES, Diogo; ALVES SILVA, Franklyn Roger. Princípios Institucionais da Defensoria Pública. $2^{\mathrm{a}}$ ed. Rio de Janeiro: Forense, 2017.

MARCACINI, Augusto Tavares Rosa. Assistência Jurídica, Assistência Judiciária e Justiça Gratuita. Rio de Janeiro: Forense, 1996. p. 71-72 apud ALVES, Cléber Francisco. Justiça para todos! Assistência Gratuita nos Estados Unidos, na França e no Brasil. Rio de Janeiro: Lumen Juris, 2006. 
MARCANI, Augusto Tavares Rosa. Assistência Jurídica, Assistência Judiciária e Justiça Gratuita. Rio de Janeiro: Forense, 1996 apud ALVES, Cléber Francisco. Justiça para todos! Assistência Gratuita nos Estados Unidos, na França e no Brasil. Rio de Janeiro: Lumen Juris, 2006.

MARINONI, Luiz Guilherme. Teoria Geral do Processo. São Paulo: Revista dos Tribunais, 2006.

MARMELSTEIN, George. Curso de Direitos Fundamentais. $6^{\mathrm{a}}$ ed. São Paulo: Atlas, 2016. 576 p.

Curso de direitos fundamentais. São Paulo: Atlas, 2008.

MARTINS, Rodrigo Bezerra. Dimensão Objetiva e Dimensão Subjetiva dos Direitos Fundamentais. Disponível em:

$<$ http://www.conteudojuridico.com.br/artigo,dimensao-objetiva-edimensao-subjetiva-dos-direitos-fundamentais,49820.html>. Acesso em: 29 out. 2017.

MEIRELLES, Hely Lopes. Direito Administrativo Brasileiro. São Paulo: Malheiros, 2013 apud ESTEVES, Diogo; ALVES SILVA, Franklyn Roger. Princípios Institucionais da Defensoria Pública. $2^{\mathrm{a}}$ ed. Rio de Janeiro: Forense, 2017.

MENDES, Gilmar Ferreira et al. Curso de direito constitucional. $3^{\mathrm{a}}$ ed. rev. atual. São Paulo: Saraiva, 2008.

2009. $1486 \mathrm{p}$.

et al. Curso de Direito Constitucional. $4^{\mathrm{a}}$ ed. São Paulo: Saraiva,

MENDES, Gilmar Ferreira. Direitos fundamentais e controle de constitucionalidade: Estudos de Direito Constitucional. $2^{\mathrm{a}}$ ed. São Paulo: Publicação do Instituto Brasileiro de Direito Constitucional, C. Bastos. 1999. 518 p.

Direitos fundamentais e controle de constitucionalidade: Estudos de Direito Constitucional. $3^{\text {a }}$ ed. São Paulo: Saraiva, 2004. 
MORAES, Alexandre de. Direitos Humanos Fundamentais. Teoria Geral. Comentários aos arts. 1o à 5o da Constituição da República Federativa do Brasil. Doutrina e Jurisprudência. 2ª ed. São Paulo: Atlas S.A., 1998.

Direitos Humanos Fundamentais. Teoria Geral. Comentários aos arts. 1o à 5o da Constituição da República Federativa do Brasil. Doutrina e Jurisprudência. 9a ed. São Paulo: Atlas S.A., 2011. 400 p.

MORAES, Guilherme Peña de. Instituições da Defensoria Pública. São Paulo: Malheiros Editores, 1999. 374 p.

MORAES, Humberto Peña de; SILVA, José Fontenelle Teixeira da Silva. Assistência Judiciária: Sua Gênese, Sua História e a Função Protetiva do Estado. Rio de Janeiro: Liber Juris, 1984. 236 p.

MORAES, Maria Celina Bodin de. A Constitucionalização do direito civil e seus efeitos sobre a responsabilidade civil. Disponível em:

<http://egov.ufsc.br/portal/sites/default/files/a_constitucionalizacao_do_dir eito_civil_e_seus.pdf>. Acesso em: 01 abr. 2018.

MORAES, Sílvio Roberto Mello. Princípios Institucionais da Defensoria Pública: Lei Complementar $n^{\circ} 80$ de 12.1.1994. São Paulo: Revista dos Tribunais, 1995. $210 \mathrm{p}$.

PAIVA, Caio. Prática Penal para a Defensoria Pública. Rio de Janeiro: Forense, 2016 apud ESTEVES, Diogo; ALVES SILVA, Franklyn Roger. Princípios Institucionais da Defensoria Pública. $2^{\mathrm{a}}$ ed. Rio de Janeiro: Forense, 2017.

PINHO, Rodrigo César Rebello. Teoria geral da Constituição e direitos fundamentais. São Paulo: Saraiva, 2010. 248 p.

ROCHA, Jorge Luís. História da Defensoria Pública e da Associação dos Defensores Públicos do Estado do Rio de Janeiro. Rio de Janeiro: Lumen Juris, 2004.

SADEK, Maria Tereza Aina. Defensoria Pública: Conquista da Cidadania, In: RÉ, Aluísio Iunes Monti Ruggeri. Temas Aprofundados da Defensoria Pública, Bahia: Jus Podivm, 2013. 
SANTOS, Boaventura de Sousa. Introdução à Sociologia da Administração da Justiça In: Revista Crítica de Ciências Sociais. nº 21, nov. 1986.

SARLET, Ingo Wolfgang. A eficácia dos direitos fundamentais. $9^{\mathrm{a}}$ ed., rev., ampl. Porto Alegre: Livraria do Advogado, 2008.

A Eficácia dos Direitos Fundamentais. Uma teoria geral dos direitos fundamentais na perspectiva constitucional. $5^{\text {a }}$ ed. Porto Alegre: Livraria do Advogado, 2005. 464 p.

SARMENTO, Daniel. Parecer sobre as dimensões constitucionais da Defensoria Pública da União. Disponível em:

$\langle$ http://www.anadef.org.br/images/Parecer_ANADEF_CERTO.pdf>. Acesso em: 03 mai. 2018.

SCHIAVON, Fabiana. Nova Lei da Defensoria dá início a Reestruturação. Disponível em: <https://www.conjur.com.br/2009-out-10/lei-defensoriaprimeiro-passo-reestruturacao-orgao >. Acesso em: 30 abr. 2018.

SILVA, José Afonso da. Comentário contextual à Constituição. $6^{\mathrm{a}}$ ed., São Paulo: Malheiros, 2009. 1027 p.

. Comentário Contextual à Constituição. $9^{\mathrm{a}}$ ed. São Paulo: Malheiros, 2014.

. Curso de Direito Constitucional Positivo. $37^{\mathrm{a}}$ ed., São Paulo: Malheiros, 2013. 934 p.

Site Oficial da Organização das Nações Unidas. Disponível em: $<$ https://nacoesunidas.org/direitoshumanos/>. Acesso em: 02 mai. 2018.

SOMMERLAD, Hilary. Some Reflections on the relationship between citizenship, access to justice, and the reform os legal aid, In: Journal os Law and Society, v. 31, no. 3, September, 2004.

SOUZA, Carlos Eduardo Freitas de.; SILVA, Bruna Gomes da. Defensoria Pública na Tutela Jurídica do Meio Ambiente. Disponível em: <https://www.anadep.org.br/wtksite/cms/conteudo/20667/CARLOS_EDU ARDO_FREITAS_DE_SOUZA_E_BRUNA_GOMES_DA_SILVA.pdf >. Acesso em: 30 abr. 2018. 
STF, MS 23.452, Rel. Ministro Celso de Mello, Rio de Janeiro, 12 mai. 2000.

TORRES, Ricardo Lobo. $O$ direito ao mínimo existencial. Rio de Janeiro: Renovar, 2009. $352 \mathrm{p}$.

TRINDADE, A. A. Cançado. Tratado de Direito Internacional dos Direitos Humanos. t. III, Porto Alegre: Fabris, 2002. p.

Voto no julgamento do Caso Damião Ximenez Lopes versus Brasil. Sentença de 31.01.2006. pars. 4452. Disponível em: $\langle$ http://www.corteidh.or.cr/docs/casos/articulos/seriec_149_por.pdf〉. Acesso em: 25 set. 2015.

WATANABE, Kazuo et al.. Acesso à Justiça e Sociedade Moderna In: Participação e Processo. São Paulo: RT Editora, 1988. 